CYNTIA WATANABE ROSA

\title{
ANÁLISE EM ORGANIZAÇÕES PARA COLABORAÇÃO EM SUSTENTABILIDADE: UM ESTUDO DE CASO
}

SÃo PAULO 
CYNTIA WATANABE ROSA

\section{ANÁLISE EM ORGANIZAÇÕES PARA COLABORAÇÃO EM SUSTENTABILIDADE: UM ESTUDO DE CASO}

Dissertação apresentada à Escola

Politécnica da Universidade de São Paulo para obtenção do título de Mestre em Engenharia 
CYNTIA WATANABE ROSA

\section{ANÁLISE EM ORGANIZAÇÕES PARA COLABORAÇÃO EM SUSTENTABILIDADE: UM ESTUDO DE CASO}

Dissertação apresentada à Escola

Politécnica da Universidade de São Paulo para obtenção do título de Mestre em Engenharia

Área de Concentração:

Engenharia de Produção

Orientador: Professor Titular

João Amato Neto 
Este exemplar foi revisado e corrigido em relação à versão original, sob responsabilidade única do autor e com a anuência de seu orientador.

São Paulo, 02 de Janeiro de 2014.

Assinatura do autor

Assinatura do orientador

Rosa, Cyntia Watanabe

Análise em organizações para colaboração em sustentabi-

lidade : um estudo de caso / C.W. Rosa. -- versão corr. -- São

Paulo, 2014.

$97 \mathrm{p.}$

Dissertação (Mestrado) - Escola Politécnica da Universidade de São Paulo. Departamento de Engenharia de Produção.

1. Sustentabilidade 2. Redes de colaboração I. Universidade de São Paulo. Escola Politécnica. Departamento de Engenharia de Produção II. t. 


\section{DEDICATÓRIA}

Dedico este trabalho aos meus pais, Eurico Inocêncio Rosa e Aparecida Watanabe, pela dedicação e amor sem limites em todos os momentos. 


\section{AGRADECIMENTO}

Ao Professor Dr. João Amato Neto, agradeço a orientação, a confiança, a oportunidade de aprendizado nas suas disciplinas e o exemplo de integridade e dedicação acadêmica. Sempre me socorrendo com a sua paciência e conhecimento.

Aos professores Dr. Fabio Guerrini e Dr. Marcelo Pessoa pelas considerações e sugestões, durante o exame de qualificação, contribuindo no desenvolvimento e aprimoramento deste trabalho.

Meus agradecimentos ao Dr. Leandro Loss, pela amizade, incentivo, contribuições e horas de trabalho compartilhado para a elaboração deste trabalho.

Ao meu amor, Rafael Kasai, pelo inestimável companheirismo, sempre me confortando com seus abraços e palavras de apoio.

Ao meu irmão Marcio Watanabe pela motivação e carinho.

A todos os meus amigos da Axia Sustentabilidade pelo companheirismo e apoio em todos os momentos.

Agradeço aos funcionários da Secretaria de Pós-graduação do Departamento de Engenharia de Produção, em especial, à Lidia Nogueira da Silva, pela eficiência e solidariedade demonstrada.

A todos aqueles que também contribuíram para a condução deste trabalho. 
Quando os ventos de mudança sopram, umas pessoas levantam barreiras, outras constroem moinhos de vento. 


\section{RESUMO}

As organizações buscam ter um posicionamento e ser atuantes em relação ao tema Sustentabilidade, devido à urgência dos desafios que ainda devem ser enfrentados em relação ao aumento da demanda da sociedade e da degradação do meio ambiente. Este tema é atual e um assunto sistêmico que deve ser considerado por todos os setores de uma organização. Em paralelo, percebe-se uma mudança na maneira como as empresas estão se configurando, na forma de redes, como alternativa às transformações econômicas. Deste modo, observa-se que os projetos que tem por objetivo promover a Sustentabilidade podem ser realizados pela formação de redes entre as organizações. Os fatores motivadores deste trabalho se devem às observações de iniciativas existentes para a promoção da sustentabilidade com o envolvimento de instituições distintas e a carência de pesquisas considerando estes assuntos. $O$ objetivo principal deste trabalho é avaliar o grau de maturidade das organizações que desejam trabalhar em forma de redes de empresas nos projetos de implantação da sustentabilidade. Para alcançar tal meta, foi realizado um estudo de caso em dois projetos que promoveram a sustentabilidade e foram concretizados com o envolvimento de organizações distintas. Os resultados obtidos permitem confirmar as proposições teóricas construídas pela pesquisadora, apontando a importância de se avaliar a maturidade das organizações que desejam trabalhar em forma de redes de empresas em projetos de aplicação da sustentabilidade.

Palavras-chave: Sustentabilidade. Redes de Colaboração. 


\begin{abstract}
Organizations are looking at having a position and be active in relation to sustainability, because of the urgency of the challenges that must be addressed in relation to the increased demand of society and environmental degradation. This theme is present, and a systemic issue that should be considered by all sectors of an organization. In parallel, there is a perceived change in how companies are shaping up in the form of networks as an alternative to the economic. Thus, it is observed that the projects that aim to promote sustainability can be achieved through business networks between organizations. The motivating factors of this work are due to observations of existing initiatives to promote sustainability with the involvement of different institutions and the lack of research considering these issues. The main objective of this work is to evaluate the maturity level of organizations who wish to work in the form of business networks in deployment projects sustainability. To achieve this goal, a case study was conducted in two projects that promoted sustainability and were implemented with the involvement of different organizations. The results obtained confirm the theoretical propositions constructed by the researcher, pointing out the importance of evaluating the maturity of organizations wishing to work in the form of networks of firms in projects applying sustainability.
\end{abstract}

Keywords: Sustainability. Collaboration Network. 


\section{LISTA DE ILUSTRAÇÕES}

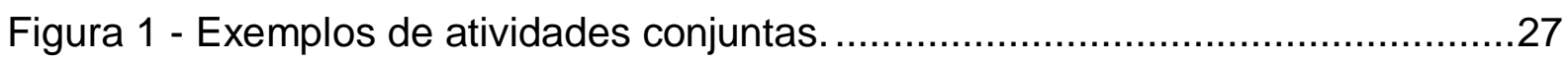

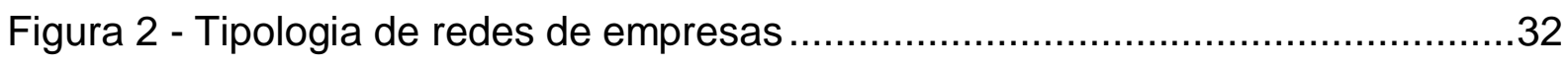

Figura 3 - Desenvolvimento Sustentável - Linha do tempo 1945-1989 .....................41

Figura 4 - Desenvolvimento Sustentável - Linha do tempo 1990-2002 …................42

Figura 5 - Desenvolvimento Sustentável - Linha do tempo 2007-2012 ....................43

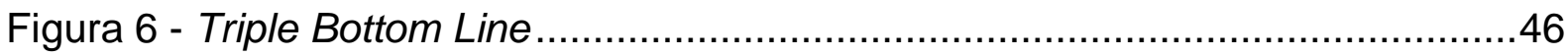

Figura 7 - Métodos e Procedimentos metodológicos ………...............................57

Figura 8 - Organização do projeto Cadeias Sustentáveis .......................................66

Figura 9 - Organização do projeto Rio Cidade Sustentável.....................................69

Quadro 1 - Síntese do referencial teórico dos aglomerados produtivos e redes

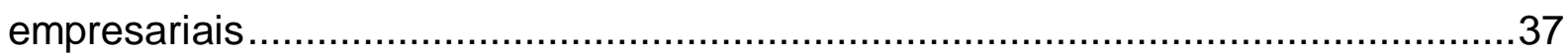

Quadro 2 - Referencial teórico sobre sustentabilidade ........................................55

Quadro 3 - Resultado do questionário - Cadeias Sustentáveis ................................72

Quadro 4 - Resultado do questionário - Rio Cidade Sustentável ..............................74 


\section{LISTA DE ABREVIATURAS}

$\begin{array}{ll}\text { APL } & \text { Arranjo Produtivo Local } \\ \text { CEBDS } & \text { Conselho Empresarial Brasileiro para Desenvolvimento Sustentável } \\ \text { CDP } & \text { Carbon Disclosure Project } \\ \text { EV } & \text { Empresa Virtual } \\ \text { GEE } & \text { Gases de Efeito Estufa } \\ \text { GRI } & \text { Global Report Initiative } \\ \text { IBASE } & \text { Instituto Brasileiro de Análises Sociais e Econômicas } \\ \text { ICO2 } & \text { Índice de Carbono Eficiente } \\ \text { ISE } & \text { Índice de Sustentabilidade Empresarial } \\ \text { JIT } & \text { Just In Time } \\ \text { ONG } & \text { Organização não Governamental } \\ \text { SPL } & \text { Sistema Produtivo Local } \\ \text { TI } & \text { Tecnologia da Informação } \\ \text { TBL } & \text { Triple Bottom Line } \\ \text { TNS } & \text { The Natural Step } \\ \text { WBCSD } & \text { World Business Council for Sustainable Development }\end{array}$




\section{SUMÁRIO}

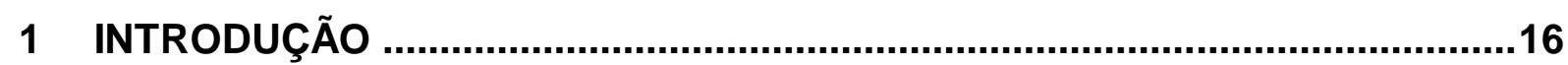

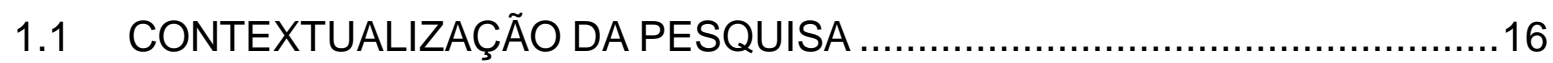

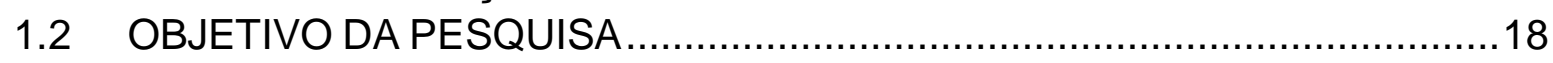

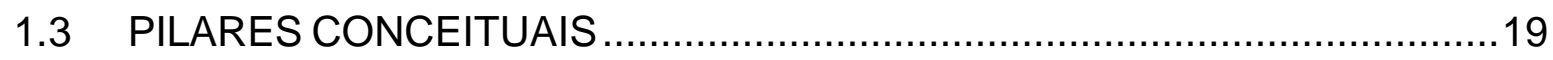

1.4 PROCEDIMENTOS DE INVESTIGAÇÃO CIENTÍFICA ……....................19

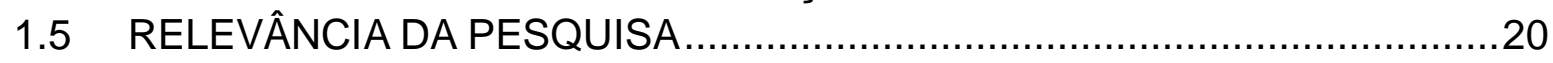

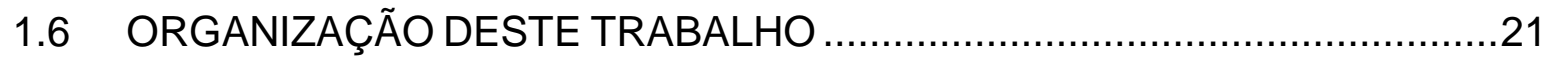

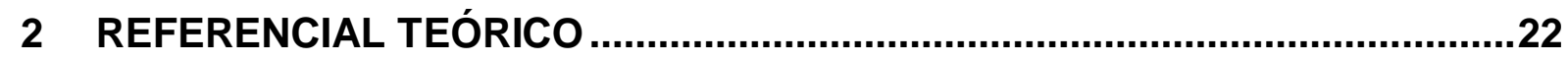

2.1 NÍVEL DE INTEGRAÇÃO ENTRE ORGANIZAÇÕES ..............................22

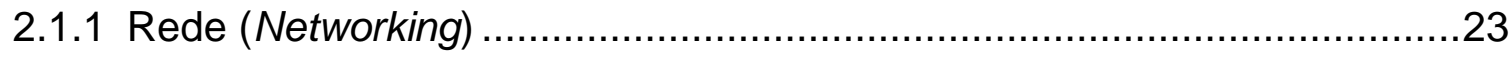

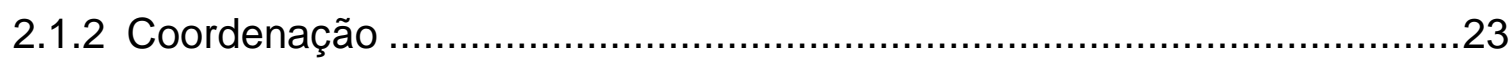

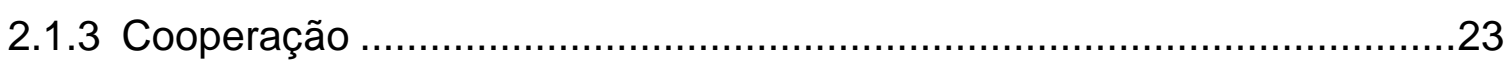

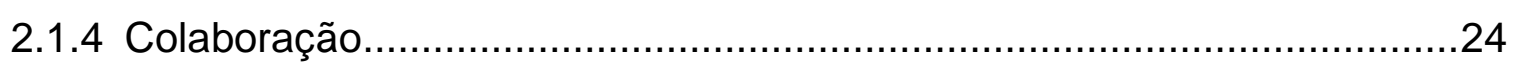

2.1.5 A cooperação entre organizações .....................................................25

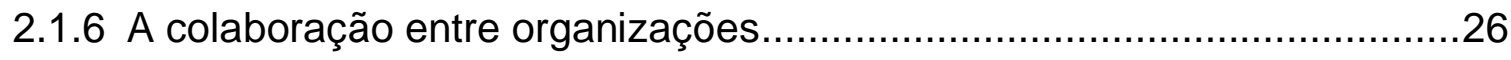

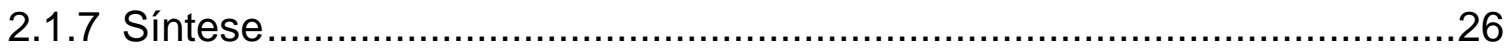

2.2 PRINCIPAIS TIPOLOGIAS DE AGLOMERADOS PRODUTIVOS E REDES

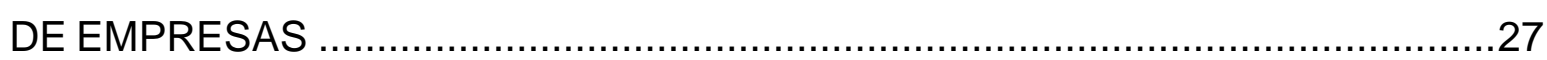

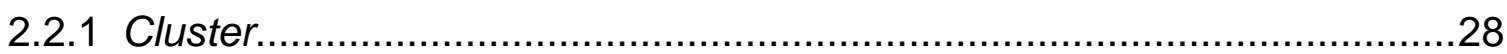

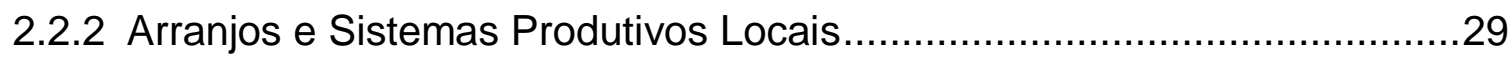

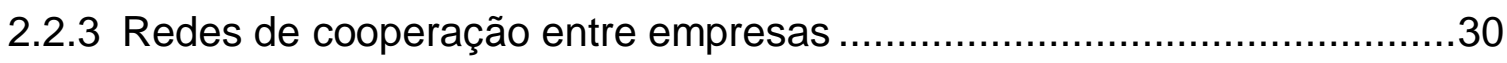

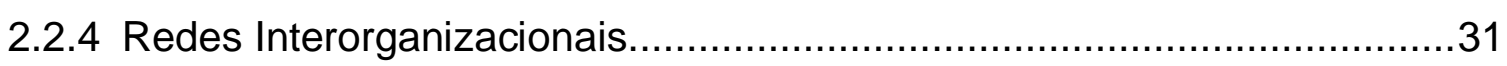

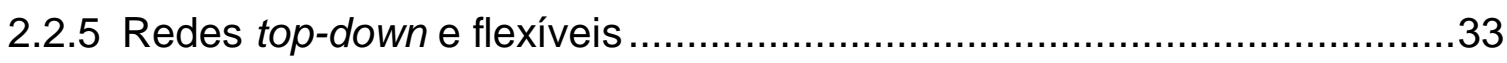

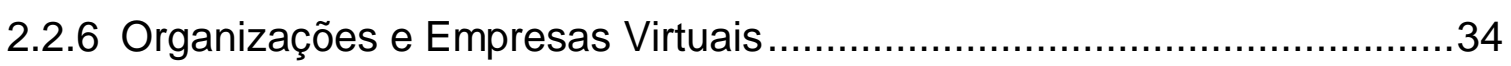

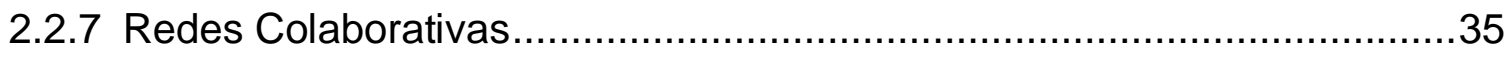

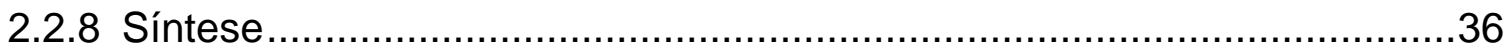

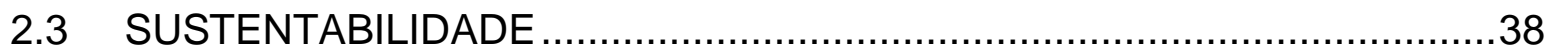

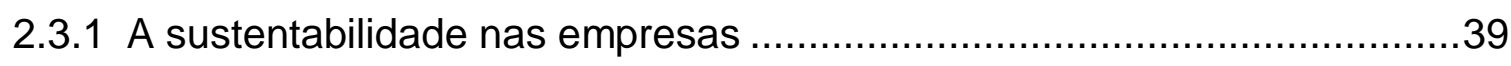

2.3.2 Desenvolvimento Sustentável: Linha do Tempo ……............................40

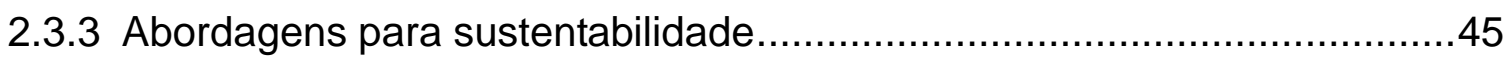

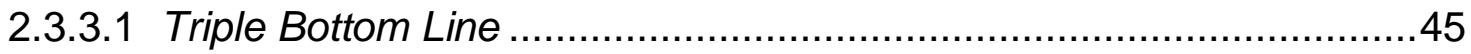

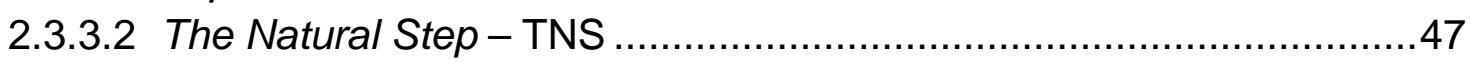

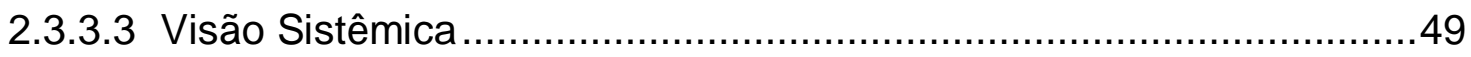

2.3.4 Ferramentas de suporte para sustentabilidade .....................................50 


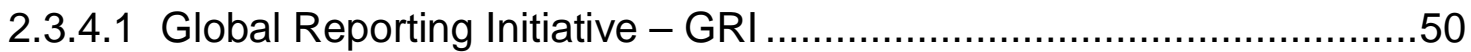

2.3.4.2 Índice de Sustentabilidade Empresarial - ISE................................50

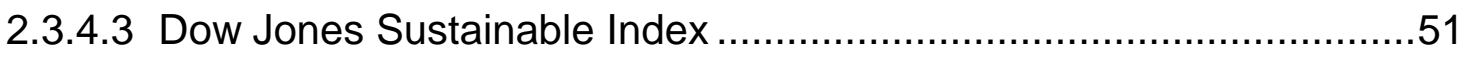

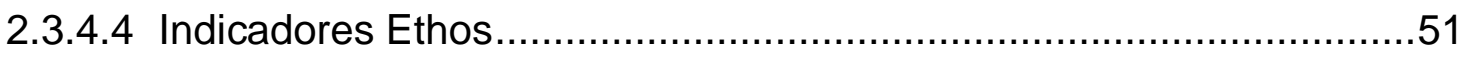

2.3.4.5 Instituto Brasileiro de Análises Sociais e Econômicas - IBASE .........51

2.3.4.6 Índice de Carbono Eficiente - ICO2 …..........................................52

2.3.4.7 Carbon Disclosure Project - CDP ..............................................52

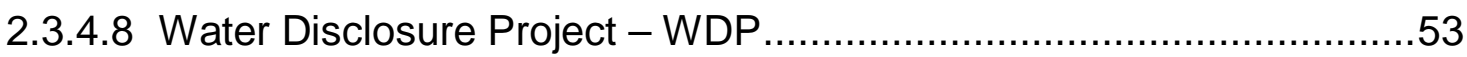

2.3.4.9 Pegada ecológica ou Pegada de carbono......................................53

2.4 PROJETOS COLABORATIVOS DE SUSTENTABILIDADE .........................54

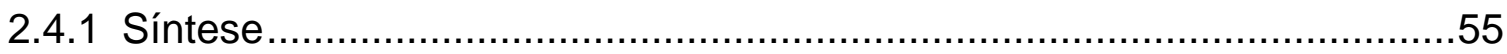

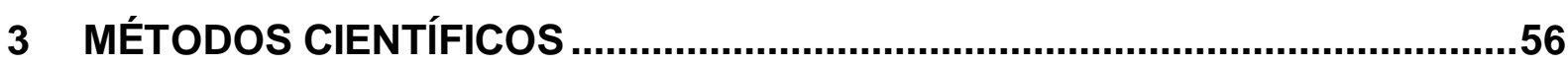

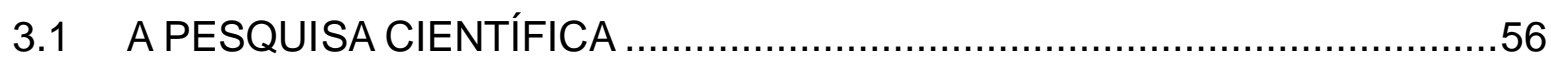

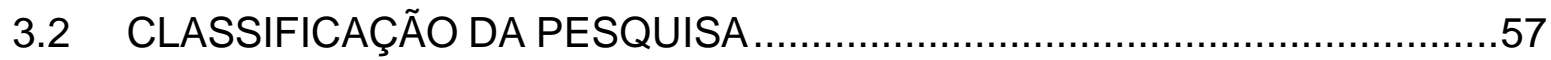

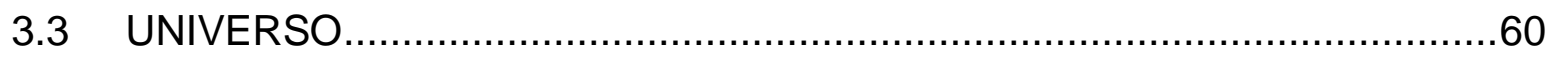

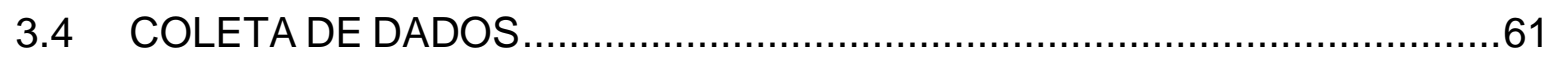

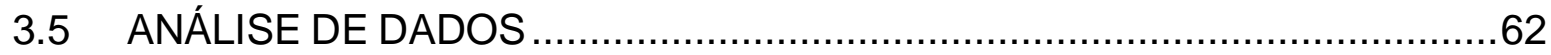

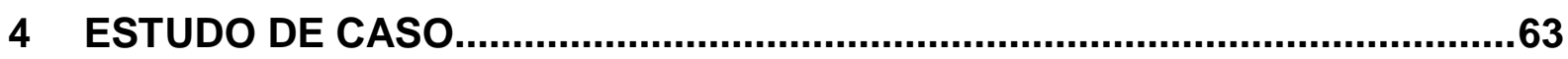

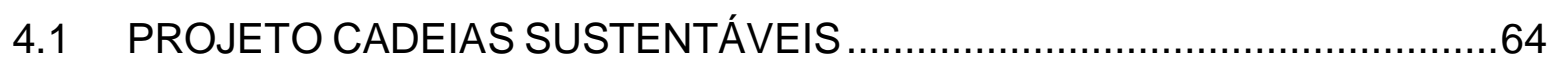

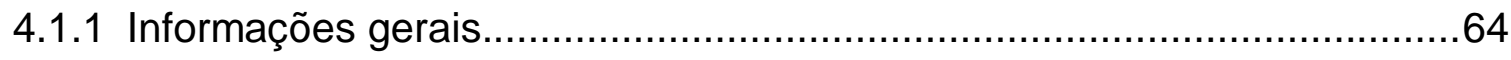

4.1.2 Plataforma de Colaboração e Educação em Sustentabilidade .................64

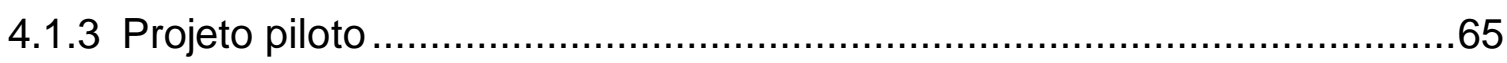

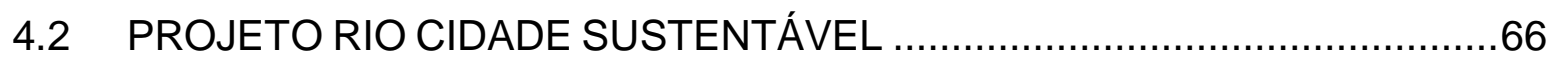

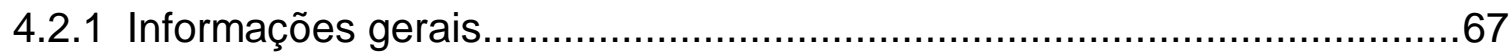

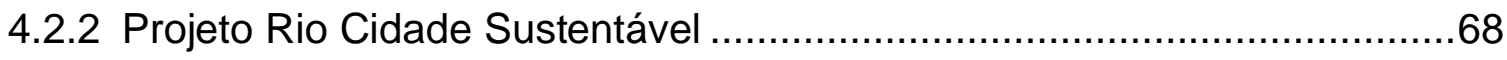

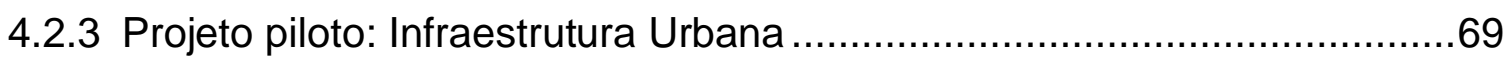

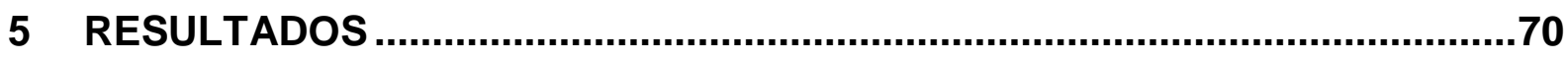

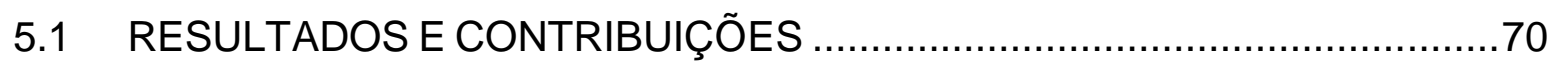

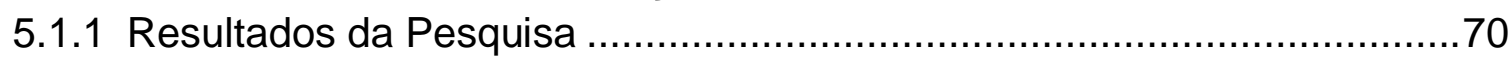

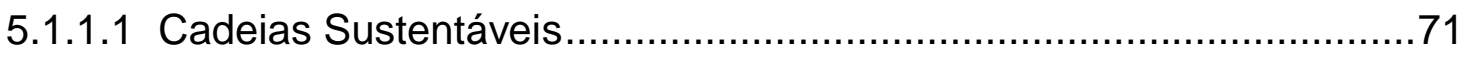

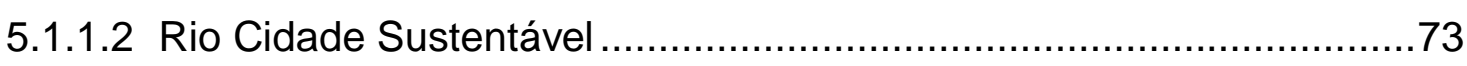

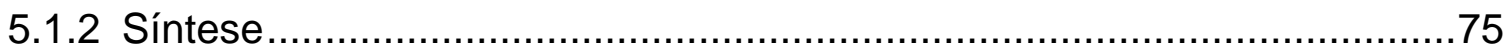

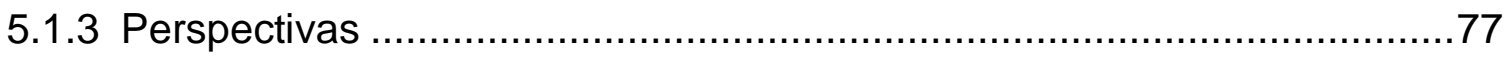

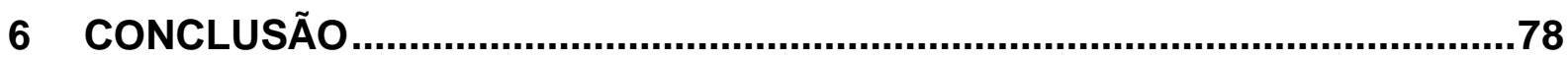

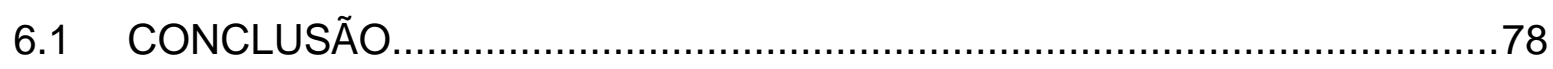

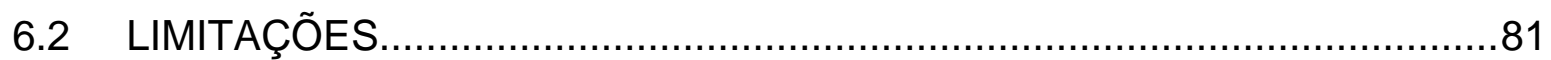

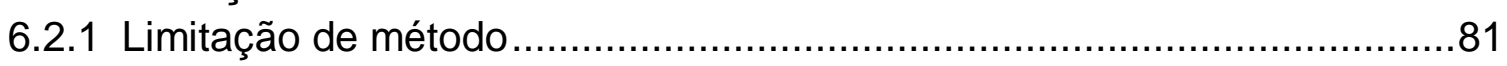


6.2.2 Limitação do modelo proposto ...................................................... 81

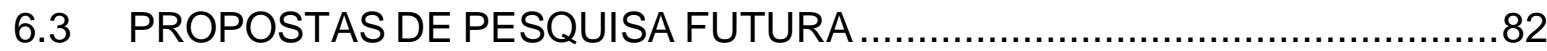

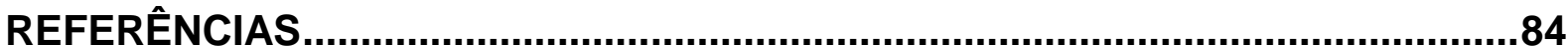

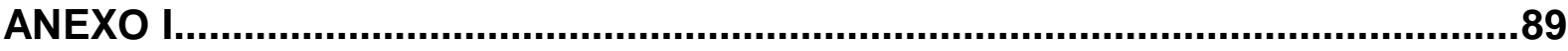

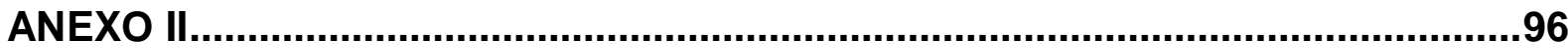

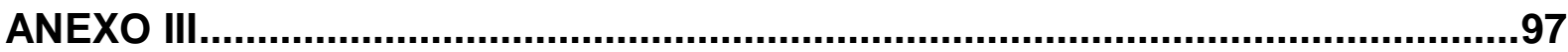




\section{INTRODUÇÃO}

Este capítulo tem como objetivo apresentar a proposta desta dissertação de mestrado. Para isto, contém uma breve justificativa e contextualização da pesquisa que leva à estruturação do problema, aos objetivos e às proposições do estudo. Ao final, é feita uma concisa descrição da metodologia utilizada e da estrutura deste trabalho.

\subsection{CONTEXTUALIZAÇÃO DA PESQUISA}

As alterações do clima, o efeito estufa, a elevação do nível do mar, o aumento progressivo da temperatura, o crescimento econômico e populacional, a longevidade dos seres humanos, a redução do ciclo de vida dos produtos e o elevado desenvolvimento tecnológico são alguns exemplos que reforçam o desequilíbrio entre o consumo pelo homem e a capacidade de reposição da natureza cujos resultados começam a impactar a qualidade de vida na Terra.

A sustentabilidade surgiu da necessidade por mudanças, pois os esforços para o desenvolvimento econômico não estavam relacionados com a melhoria do bemestar humano, muito menos com a proteção dos recursos naturais e da degradação do meio ambiente. Por isso, ela pode ser articulada para analisar e gerenciar as atividades humanas, especialmente o que diz respeito à natureza, recursos e desenvolvimento.

A importância do tema está na urgência dos desafios que ainda devem ser enfrentados, incluindo mudanças em escala global, como a enorme e crescente explosão demográfica, as disparidades socioeconômicas e o aumento da degradação ambiental (GARCIA, 2009).

Para reverter ou reduzir tais problemas, a implantação da sustentabilidade só ocorre via desenvolvimento sustentável - a descoberta, a execução, a criação e a adaptação de instituições, políticas, estratégias e tecnologias para satisfazer as necessidades em ambiente saudável e socialmente justo, de modo a não 
comprometer a possibilidade de outros seres humanos fazerem o mesmo, agora e no futuro.

E nos últimos 60 anos, o mundo vem debatendo com maior ênfase as relações entre as pessoas, as empresas, os negócios e o planeta. As décadas de 1970 e 1980 apresentaram contribuições importantes sobre o assunto, como o livro Limites do Crescimento, em 1972, que evidencia o perigo do excesso e do colapso global, afirmando que a sociedade continuará a crescer e aproximar-se dos seus limites, sem agir até que seja tarde demais; e em 1987, com a publicação do relatório pioneiro Nosso Futuro Comum, Relatório de Brundtland (Brundtland, 1991), que pressupõem um dos modelos iniciais de desenvolvimento sustentável.

Em paralelo, as grandes mudanças na economia global estão afetando a maneira como as redes de empresas operam. Estudos realizados nas décadas de 1980 e 1990 analisaram o crescimento industrial e regional, atribuindo o sucesso da reestruturação das empresas e do entorno à maneira como elas enfrentaram os novos desafios colocados, estabelecendo melhorias nas atividades de competição, colaboração e cooperação. (POLENSKE, 2004, p.1030).

Segundo Reis (2008, p.14), as empresas passaram a buscar um modelo mais enxuto e flexível, crescendo, portanto, a necessidade das organizações se concentrarem nas suas principais competências e, paralelamente, estabelecerem parcerias para desenvolverem produtos, serviços e processos, estando aptos a responderem com mais facilidade às mudanças contínuas do ambiente e à necessidade de produção de inovações.

Diante deste cenário, percebe-se que ao invés de se empenhar na busca por mais recursos, em um período de tempo cada vez mais curto, uma saída para as companhias pode ser proporcionar o envolvimento com organizações distintas na solução de problemas para superar suas limitações econômicas e estruturais. Para isto, algumas organizações realizam um trabalho pioneiro e inovador no intuito de melhorar a eficiência buscando soluções sustentáveis diante das dificuldades, através da aplicação da colaboração entre os atores.

Entretanto, o simples fato de envolver outras organizações de forma colaborativa não resolve o problema. É necessário verificar o quanto elas, que desejam trabalhar em forma de redes, estão preparadas para trabalhar de forma conjunta em projetos que visam promover a sustentabilidade. 
Portanto, o presente trabalho é inspirado em problemas identificados em casos atuais sobre o tema de redes de colaboração, sustentabilidade e, principalmente, na maneira como as organizações tem se estruturado no intuito de desenvolver projetos que necessitam envolver diversos atores.

A relevância deste assunto está na atualidade do conceito envolvido, Sustentabilidade, e sua relação com temas mais amplos, como colaboração e cooperação. Por conseguinte, a ênfase deste material está na avaliação do grau de maturidade das organizações para atuarem de forma colaborativa no desenvolvimento de projetos sustentáveis.

Assim, o resultado deste trabalho concentra o estudo das organizações que desejam trabalhar em forma de redes de empresas nos projetos de aplicação da sustentabilidade. Sendo tal paradigma motivado pelas seguintes razões: redes de colaboração e sustentabilidade.

Em suma, ao estudar esses casos, nota-se que o problema crítico é verificar se as organizações estão preparadas para atuarem em forma de redes de empresas em projetos que visam promover a sustentabilidade. Portanto, a questão central que requer pesquisa aprofundada é:

Quais as características essenciais que uma empresa deve apresentar para atuar em colaboração no desenvolvimento de projetos que promovam a sustentabilidade?

Esta questão nos leva a compreender o objetivo da pesquisa, propostos a seguir.

\subsection{OBJETIVO DA PESQUISA}

Este trabalho visa apresentar uma análise com o seguinte objetivo: avaliar o grau de maturidade em sustentabilidade e o engajamento colaborativo nas organizações que desejam trabalhar em forma de redes de empresas nos projetos de promoção da sustentabilidade. 


\subsection{PILARES CONCEITUAIS}

O referencial teórico que sustenta esta pesquisa fundamenta-se nas mais recentes contribuições conceituais, embasadas nos termos:

- Colaboração;

- Cooperação;

- Redes de colaboração;

- Sustentabilidade.

\subsection{PROCEDIMENTOS DE INVESTIGAÇÃO CIENTÍFICA}

O método de resolução de problemas empregado no presente trabalho foi de natureza aplicada, visando pesquisa exploratória e abordagem qualitativa. O procedimento técnico selecionado foi a pesquisa bibliográfica e o estudo de caso foi utilizado no levantamento de dados qualitativos, interpretação e análise, para assim alcançar o objetivo proposto nesta dissertação.

Os casos que estabeleceram o escopo desta pesquisa são projetos que se caracterizam como redes entre organizações distintas para o desenvolvimento de projetos de sustentabilidade. O primeiro caso analisado ilustra a relação entre o setor de varejo e a indústria. Já, o segundo caso, representa a relação entre empresas privadas e organizações do primeiro e segundo setor.

A coleta de dados foi realizada pela aplicação de questionário. Os dados estão analisados e apresentados em quadros, acompanhados pela análise da autora deste trabalho.

A partir disto, pretende-se que as evidências que são apresentadas como validação da proposta e os resultados finais possam contribuir com a teoria vigente e com a identificação de pesquisas futuras - compreendendo assim, os resultados e as conclusões da presente pesquisa. 


\subsection{RELEVÂNCIA DA PESQUISA}

Durante os últimos anos, uma grande variedade de formas de colaboração em rede tem surgido para enfrentar as dificuldades encontradas no mundo dos negócios. Um dos aspectos que estimulou sua utilização foi o rápido progresso das tecnologias de informação e comunicação. Além disso, o aumento da disponibilidade de tecnologia permitiu às organizações alcançar novos mercados, ou lutar contra dificuldades, por meio da construção de relacionamentos entre elas. Ao adotar a abordagem de redes de colaboração, uma companhia pode concentrar esforços somente em suas competências essenciais, compartilhando competências com outras empresas especializadas a fim de oferecer produtos e serviços com maior valor agregado (BALDO, 2008, p.17).

Este trabalho parte do pressuposto de que a forma mais adequada para uma organização atingir suas metas ao realizar projetos que aplicam o conceito de sustentabilidade é pelas redes de colaboração.

Contudo, um fator observado refere-se ao fato de que os conceitos de redes de colaboração não abordam sobre as características que uma organização deve apresentar para participar e garantir o desenvolvimento deste relacionamento.

Por isso, esta pesquisa pretende proporcionar uma avaliação para verificar se as organizações possuem as características necessárias para atuar em forma de rede colaborativa no desenvolvimento de projetos sustentáveis.

Assim, os resultados deste trabalho poderão servir como um referencial para as organizações realizarem a autoavaliação do quanto estão preparadas para trabalhar de forma colaborativa em projetos de sustentabilidade.

Com o parecer desta avaliação, cada organização pode desenvolver planos de melhoria para os critérios mais deficientes e, principalmente, ter uma clareza sobre suas competências para trabalhar de forma colaborativa em projetos de aplicação sustentável. 


\subsection{ORGANIZAÇÃO DESTE TRABALHO}

Este trabalho está organizado em 6 capítulos. O primeiro refere-se à Introdução; o segundo aborda o Referencial Teórico, apresentando as contribuições conceituais que fundamentam o tema e a problemática de pesquisa. O terceiro capítulo discute os Métodos Científicos, técnicas e materiais aplicados a partir do enfoque da natureza do problema e dos objetivos desta pesquisa, respeitando os pressupostos gerais e a organização do trabalho. O quarto capítulo, Estudo de Caso, apresenta o escopo do trabalho delineado pelos casos experimentais analisados. O quinto capítulo, Resultados, parte da avaliação do material obtido pelas empresas para determinar os resultados e contribuições. E por fim, o sexto capítulo reúne as principais informações obtidas nas seções anteriores para elaborar as considerações finais deste trabalho, descrevendo as contribuições e as restrições à teoria de redes de colaboração e sustentabilidade, limitações e propostas de estudos futuros. 


\section{REFERENCIAL TEÓRICO}

Este capítulo tem o objetivo de apresentar a base teórica que deu sustentação a este trabalho e que serviu de referência na análise do estudo de redes de colaboração e sustentabilidade.

Discute-se o conceito de colaboração e cooperação, assim como as formas possíveis das empresas integrarem-se para promover redes de empresas. Em seguida, é apresentado o conceito de sustentabilidade, sua evolução ao longo do tempo, abordagens e ferramentas para aplicação.

A conclusão do capítulo apresenta uma visão integrada e comparativa dos tipos possíveis de redes de empresas, mostrando uma estrutura para planejamento de desenvolvimento sustentável nas organizações.

\subsection{NÍVEL DE INTEGRAÇÃO ENTRE ORGANIZAÇÕES}

Este estudo dá atenção às formas de organização entre empresas que por meio da colaboração, criam diferenciais competitivos e significativos para contribuir na execução de atividades visando um objetivo em comum.

Esta seção descreve os tipos de coalizões existentes que antecedem a colaboração, sendo respectivamente: rede, coordenação, cooperação e colaboração.

Para Polenske (2004), colaboração e cooperação são formas similares de comportamento coletivo e possuem características semelhantes: ambos acontecem entre atores (empresas públicas ou privadas, organizações locais, agentes locais, nacionais e internacionais); as interações acontecem entre as organizações na forma de associações e uniões; e podem ser adotadas para reforçar a competitividade de uma organização. 


\subsubsection{Rede (Networking)}

Envolve a comunicação e a troca de informações para benefício mútuo. Segundo Souza (2003), networking ou rede é um conjunto de técnicas e atitudes cuja aplicação requer um comportamento natural de solidariedade e de ajuda recíproca de todos os envolvidos, havendo uma permanente interdependência nas redes de relacionamento - grupo, sociedade ou comunidade. Já para Passos (2007), a rede permite estabelecer parcerias, os network partners, que poderão apresentar, indicar ou efetivamente persuadir e influenciar pessoas responsáveis na tomada de decisão, como contratar um conhecido para um emprego fixo ou um serviço temporário.

\subsubsection{Coordenação}

Além da troca de informações, a coordenação envolve o alinhamento de atividades para que se possam obter resultados melhores e mais eficientes. Um dos principais componentes desta é o ato de trabalhar em conjunto de maneira harmoniosa.

\subsubsection{Cooperação}

De acordo com Polenske (2004), relacionamentos de cooperação ocorrem quando dois ou mais atores concordam através de disposições formais ou informais em compartilharem informações como suporte de gestão, técnicas de treinamento e informações de mercado. Este relacionamento costuma ser externo e horizontal. Segundo Amato Neto (2000), cooperação pode atender a uma série de necessidades que seriam difíceis de conseguir isoladamente, tais como combinar competências e utilizar know-how de outras organizações; dividir os custos das pesquisas tecnológicas; dividir os riscos e os custos quando se busca novas oportunidades; melhorar a qualidade de seus produtos; aumentar a competitividade; 
compartilhar recursos; e adquirir força para expandir e alcançar os mercados internacionais.

Para Camarinha-Matos e Afsarmanesh (2006), o termo engloba mais do que a troca de informações sobre atividades, ele envolve também o compartilhamento de recursos para que possam atingir objetivos compatíveis.

Acrescente a isto, a definição da Comissão Europeia (EUROPEAN COMISSION, 2004), na qual colaboração pode ser compreendida como a relação entre parceiros independentes que combinam seus esforços e recursos em um processo conjunto de criação e agregação de valor.

\subsubsection{Colaboração}

Segundo Polenske (2004), relacionamentos de colaboração são definidos para incluir participação direta de dois ou mais atores no design, no processo e na fabricação de um produto. A relação entre eles geralmente é interna e vertical, podendo envolver outras divisões internas dentro da mesma organização ou ao longo de uma cadeia de suprimentos.

"Colaboração ocorre quando um grupo de 'autonomous stakeholders"', com domínio de um problema, se envolvem em um processo interativo, dividindo papeis, normas e estruturas, para agir ou decidir questões relacionadas ao problema" (GRAY e WOOD, 1991).

Camarinha Matos e Afsarmanesh (2006) acrescentam reconhecendo que ela também consiste no processo em que as organizações compartilham informações, recursos e responsabilidades para que, juntos, possam planejar, implementar e avaliar um programa de atividades visando a mesma meta. Implicando nisto, o compartilhamento de riscos, recursos, responsabilidades e recompensas.

\footnotetext{
${ }^{1}$ Stakeholders significa atores envolvidos ou parte interessada no processo.
} 


\subsubsection{A cooperação entre organizações}

Analistas estudaram o sucesso de pequenas empresas que se agruparam em regiões na Itália e prosperaram em um ambiente inovador e cooperativo, identificando as principais características que promoveram tal desempenho (POLENKSE, 2004).

A maioria destas instituições era de base artesanal, com equipamentos flexíveis, trabalho intensivo nas etapas de produção, constante inovação de produtos e processos e, em destaque, a criação de cooperativas (organizações regionais para dividir os custos de produção). Segundo Polenske (2004), o triunfo deste caso pode ser atribuído à fronteira geográfica que ajudou a promover e manter a inovação e a cooperação dentro de um espaço delimitado.

Já alguns agrupamentos de empresas estudados na França, Alemanha e Espanha (HERRIGEL apud POLENSKE, 2004,) indicaram que os distritos industriais não são fatos isolados. Essas associações prosperam em um determinado ambiente, limitado geograficamente, e passam a ser reconhecidos econômica e politicamente. As causas da prosperidade destas empresas estão relacionadas à inovação e aos arranjos cooperativos estabelecidos internamente.

Portanto, as redes de inovação são necessárias para assegurar o sucesso destes distritos, pois ajudam a reduzir os custos de transação, promovem o aprendizado coletivo, vinculam os avanços tecnológicos ao mercado, estabelecem normas e padrões, entre outros benefícios. Segundo Saxenian (1994), a inovação contínua, a oportunidade e o rápido desenvolvimento de novos produtos requer a cooperação entre empresas.

Desta forma, essa relação permite que as empresas inovem e reduzam os custos de transação, assegurando a cada instituição o desenvolvimento e o acesso a serviços que antes seriam inviáveis financeiramente, se estivessem disputando sozinhas no mercado. 


\subsubsection{A colaboração entre organizações}

As observações descritas nesta seção foram baseadas em estudos realizados em empresas japonesas que passaram por uma transição na organização industrial na década de 1980 (POLENSKE, 2004).

A colaboração foi observada na relação entre grandes empresas que terceirizavam parte de seus serviços para outros menores. Pois, o foco estava no estabelecimento de relacionamentos de longo prazo, reduzindo o tempo de adaptação, os custos de transação e reforçando a eficiência da comunicação entre elas.

Como resultado, o agrupamento de pequenas empresas perto de grandes organizações no Japão permitiu a produção just in time ${ }^{2}$ (JIT), eficiência de processos e descentralização da rede de fornecedores (composta, na maioria, por pequenas e médias empresas). Além disso, corroborou para as relações de confiança entre gestores e funcionários e o relativo controle do trabalho por parte dos proprietários (POLENSKE, 2004).

Assim, a apuração deste material esclarece que a colaboração toma forma ao estabelecer um relacionamento de confiança a longo prazo entre estas empresas e seus funcionários.

\subsubsection{Síntese}

As definições apresentadas no início deste capítulo estão representadas na Figura1. Segundo Camarinha-Matos e Afsarmanesh (2006), cada bloco desta figura constitui um "bloco de construção", ou passo, para a próxima definição, onde coordenação estende o conceito de networking, cooperação estende coordenação e, finalmente, colaboração estende cooperação. Quanto mais alta a camada destes blocos, maior é o comprometimento e a quantidade de recursos investidos pelos parceiros.

Apesar de a cooperação ser definida pela literatura como um mecanismo importante para a viabilização da inovação e da redução de custos de transação, proporcionando o aumento de competitividade, pode-se concluir que a colaboração

\footnotetext{
2 Just in time: sistema de gestão de produção que determina o controle da produção enquanto o bem é fabricado. O método permite que se reduza gastos e espaço alocado pelo monitoramento da compra, produção e transporte.
} 
vai além da cooperação, pois além dos benefícios acima, ocasionados pelo compartilhamento de objetivos compatíveis, ela também proporciona o trabalho e a criação em conjunto concomitantemente com a construção de uma identidade em comum.

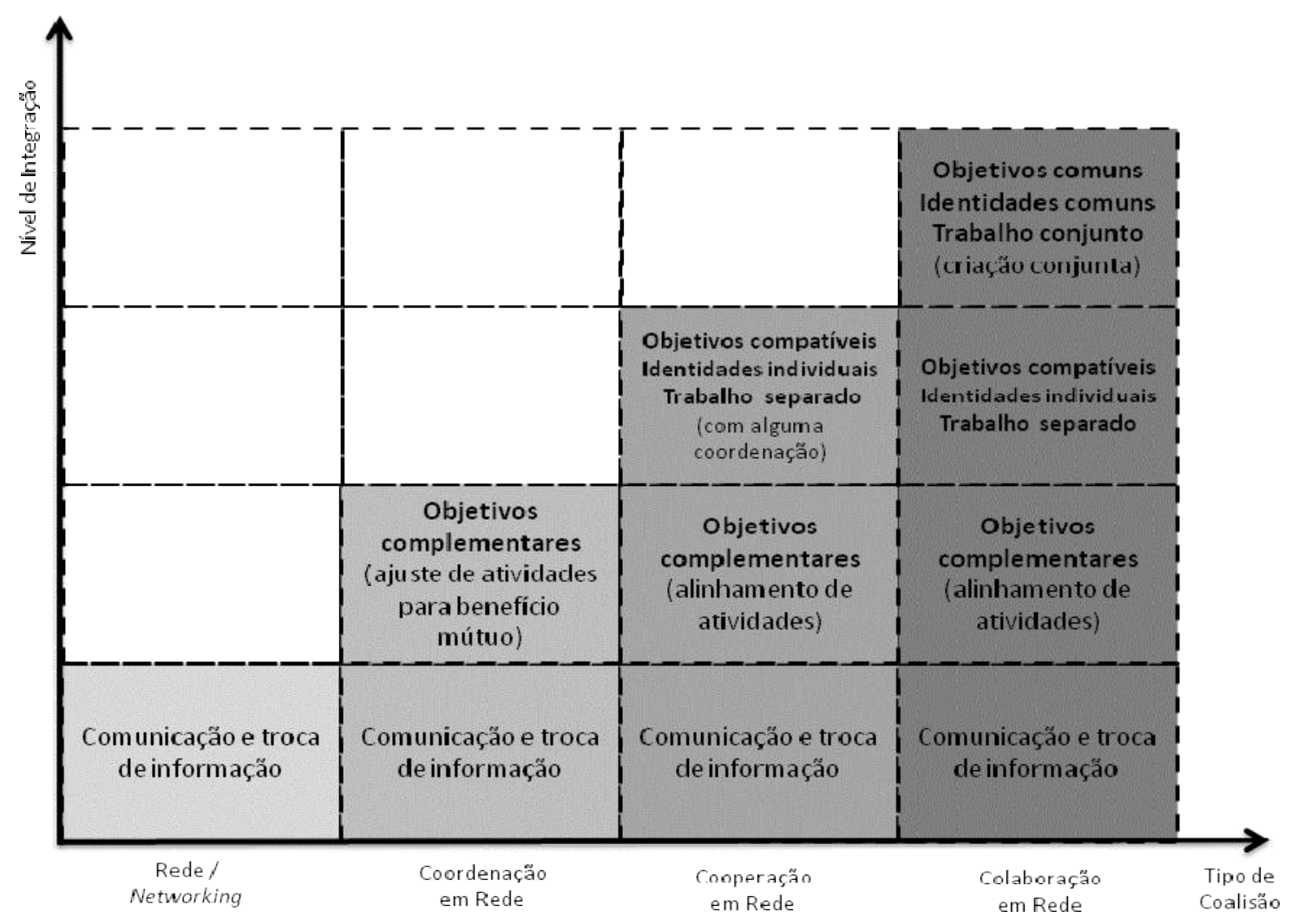

Figura 1- Exemplos de atividades conjuntas.

Fonte: Camarinha-Matos e Afsarmanesh (2006).

\subsection{PRINCIPAIS TIPOLOGIAS DE AGLOMERADOS PRODUTIVOS E REDES DE EMPRESAS}

$\mathrm{Na}$ literatura, em virtude das várias vertentes teóricas sobre aglomerações produtivas, surgem diferentes designações sobre as concentrações geográficas, mas muitas vezes, acabam convergindo em significados semelhantes. Arranjos produtivos locais (APL's), sistemas produtivos locais (SPL's), parques tecnológicos, clusters regionais, entre outras denominações, tem em comum os ganhos de eficiência coletiva que podem ser alcançados pela economia de ações (REIS, 2008). 
A seguir, são apresentadas as principais formas de aglomerações produtivas e suas definições.

\subsubsection{Cluster}

O conceito usual de cluster revela concentrações geográficas de empresas e instituições interligadas em uma área privada, onde se podem encontrar indústrias correlatas e de apoio, ou outras organizações importantes como instituições e associações governamentais, centro de pesquisa, etc. (ENRIGTH, 1998).

Dentre as características dos clusters, a mais importante é o ganho de eficiência coletiva vinculada a vantagem competitiva derivada das economias externas e locais e da ação conjunta entre os atores que os compõem. (SCHMITZ, 1989).

Como na visão de Amato Neto, que afirma:

clusters são formados apenas quando ambos os aspectos, setorial e geográfico, estão concentrados. De outra forma o que se tem são apenas organizações de produção em setores e geografia dispersa, não formando, portanto um cluster (...). (Amato Neto, 2009)

Para este pesquisador, um cluster envolve um propósito claro sobre a divisão de tarefas entre empresas, bem como para a especialização e inovação - elementos essenciais para a competição além dos mercados locais. Outro ponto observado é que a ação conjunta entre estas organizações conta com espaço significativo nestes grupos, o que não ocorre em sistemas dispersos.

Buscando também uma definição para o termo, os especialistas da Comissão Europeia (EUROPEAN COMMISSION, 2002) determinam que clusters são grupos de empresas independentes e de instituições associadas que são: de natureza competitiva e colaborativa; geograficamente concentradas em uma ou mais regiões; especializadas em uma área específica, integradas por tecnologias e habilidades comuns; e que podem ser tradicionais ou não.

Assim, para finalizar, por Porter (2009) é possível observar que barreiras são rompidas dentro deste território, baseadas na identidade e comunicação, pois para ele cluster é um agrupamento geograficamente concentrado - normalmente, reunido em regiões e, às vezes, em uma única cidade - de empresas inter-relacionadas e 
instituições correlatas numa determinada área, vinculadas por tecnologias e habilidades comuns; onde costuma existir uma facilidade para comunicação, logística e interação pessoal.

\subsubsection{Arranjos e Sistemas Produtivos Locais}

Segundo o Banco Nacional de Desenvolvimento Econômico e Social (BNDES), arranjo produtivo local (APL) é:

\footnotetext{
uma concentração geográfica de empresas e instituições que se relacionam em um setor particular. Inclui, em geral, fornecedores especializados, universidades, associações de classe, instituições governamentais e outras organizações que proveem educação, informação, conhecimento e/ou apoio técnico e entretenimento. (LASTRES et al., 2003).
}

Portanto, a abordagem de arranjos ou sistemas produtivos locais parte de um conceito amplo de aglomeração produtiva, englobando todos os tipos referidos na literatura (distritos, clusters, polos industriais, entre outros), para em seguida enquadrá-los em "um conjunto específico de atividades econômicas que possibilite e privilegie a análise de interações, particularmente as que levem à introdução de novos produtos e processos" (LASTRES et al., 2003).

Assim, com a colaboração de Lastres, a definição proposta pela Rede de Pesquisa em Sistemas Produtivos e Inovativos Locais (RedeSist) caracteriza arranjos produtivos locais como aglomerações territoriais de agentes econômicos, políticos e sociais interligados por vínculos - muitos deles ainda incipientes -, cujo foco é um conjunto específico de atividades econômicas. Por isso, a necessidade de obter a participação e interação de empresas, instituições públicas e privadas voltadas para formação e capacitação de recursos humanos, pesquisa, desenvolvimento e engenharia, política, promoção e financiamento (LASTRES et al., 2003).

Desta forma, o sistema APL foi desenvolvido para estudos e análises de países emergentes, como o Brasil, onde a heterogeneidade entre regiões é uma importante variável explicativa das trajetórias de desenvolvimentos locais, afinal estudos empíricos de países desenvolvidos e com características substancialmente divergentes das nossas não permitiam aprofundar o conhecimento sobre a realidade local dos países em desenvolvimento (ENDERLE et al., 2005). 
Como resultado, os APL's auxiliam na superação de problemas tratados por abordagens tradicionais que se mostram frequentemente insuficientes e até inadequadas; demonstrando a relevância das especificidades locais nos processos produtivos, assim como suas adaptações para conquistar mercado (LASTRES et al., 2003).

\subsubsection{Redes de cooperação entre empresas}

Para Casarotto Filho e Pires (2001), redes de empresas são "o conjunto de empresas entrelaçadas por relacionamentos formais ou simplesmente negociais, podendo ou não estar circunscritos a uma região".

Logo, rede de cooperação entre empresas pode ser resumido como método organizacional de atividades econômicas via coordenação e/ou cooperação interfirmas (PORTER, 2009).

Já para a Comissão Europeia, ela abrange mais do que a visão econômica ao informar que redes ou networks são organizações formais ou informais que facilitam a troca de informação e tecnologia e dão suporte a vários tipos de processos coordenados e colaborativos em um cluster (EUROPEAN COMISSION, 2002). Analisando sua estrutura, Amato Neto (2000) informa que uma rede pode ser configurada por meio de cooperação do tipo vertical (ao longo da cadeia) e do tipo horizontal (entre empresas concorrentes do mesmo setor), conforme explicado a seguir:

- redes verticais de cooperação normalmente são encontradas entre uma empresa e os componentes oriundos dos diferentes elos ao longo de uma cadeia produtiva;

- redes horizontais de cooperação são aquelas nas quais as relações de cooperação se dão entre empresas que produzem e oferecem produtos similares, pertencendo, portanto, a um mesmo setor ou ramo de atuação, ou seja, entre uma empresa e seus próprios concorrentes. 
Mas para isso acontecer, Oliver (1990, p.242) declara que a formação de redes de empresas pode ser motivada pelos seguintes fatores:

a) imposição legal ou determinação de uma instância superior: como no caso de certas linhas de financiamento, nas quais é permitido acesso somente a consórcios entre empresas e instituições de pesquisa;

b) controle ou assimetria: uma companhia procura exercer poder sobre outra ou pretende administrar seus recursos;

c) reciprocidade: relações estabelecidas por organizações que compartilham os mesmos objetivos, iniciando, assim, relações de cooperação e coordenação;

d) necessidade de maior eficiência interna: uma empresa, preocupada em aprimorar sua capacidade, estabelece relações com outras para reduzir seus custos de transação;

e) estabilidade: uma companhia procura se relacionar com outras empresas para diminuir sua vulnerabilidade diante do cenário competitivo;

f) legitimidade: quando uma empresa pretende melhorar sua reputação e/ou imagem através do estabelecimento de relações com organizações aceitas e respeitadas em seu meio ou no mercado.

\subsubsection{Redes Interorganizacionais}

Grandori e Soda (1995, p.199) propõem uma nova tipologia, conhecida como Redes Interempresariais (ver Figura 2). Segundo eles, as redes são descritas e classificadas como: sociais, burocráticas e proprietárias, de acordo com o grau de formalização, centralização e mecanismos de cooperação, gerados em cada rede. 


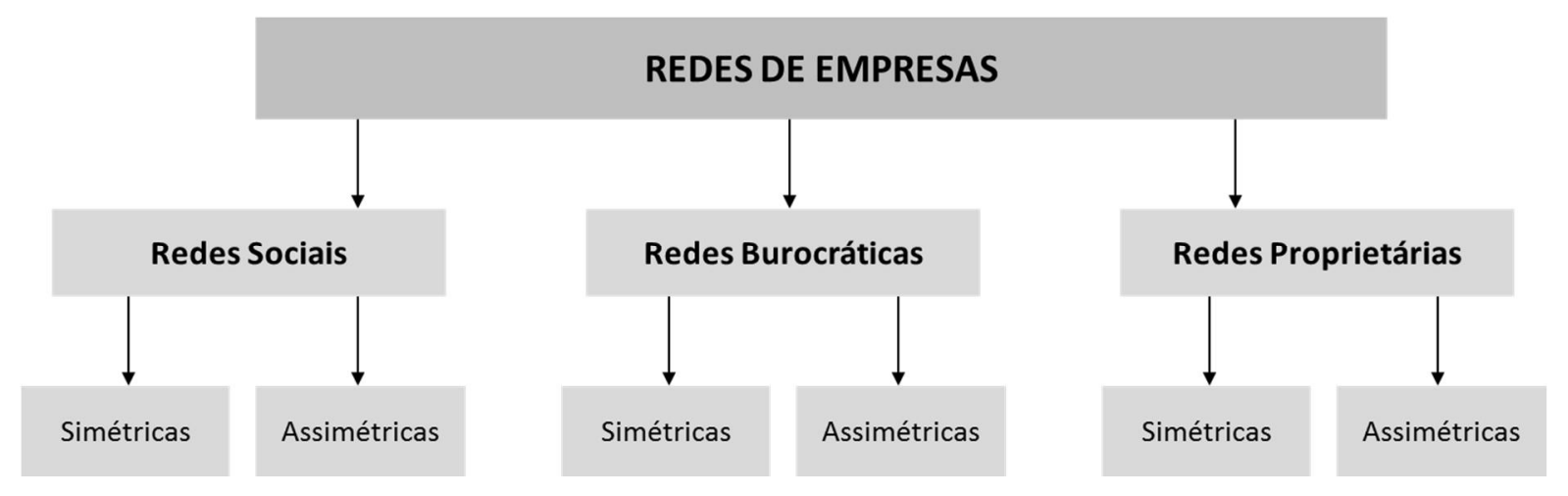

Figura 2 - Tipologia de redes de empresas

Fonte: Grandori \& Soda (1995).

Assim, elas podem ser descritas da seguinte forma:

- Redes sociais: grupos em que as relações não estão condicionadas a acordos formais, de nenhum tipo. Existem dois tipos de redes sociais, as simétricas e as assimétricas.

> Redes Sociais Simétricas: não existe um ator central, todos os participantes tem a mesma capacidade de influência. Este tipo de rede é aconselhável para estimular desenvolvimentos de caráter exploratório, onde as informações tratadas apresentam alto potencial, mas possuem valor desconhecido.

Redes Sociais Assimétricas: caracterizam-se pela presença de um agente central. Há frequentes contratos formais entre as organizações deste tipo de arranjo referindo-se às especificações de produtos ou serviços negociados, mas não à gestão do relacionamento.

- Redes Burocráticas: determinadas pela existência de um contrato formal destinado a regular as especificações de fornecimento de produtos e/ou serviços, a organização da rede e as condições de relacionamento entre seus membros. Elas são divididas em simétricas e assimétricas.

$>$ Redes Burocráticas Simétricas: identificadas por acordos formais entre diversas firmas, mas desvinculadas de interesses particulares. Colaborando com este perfil de rede há as associações comerciais e os consórcios.

Redes Burocráticas Assimétricas: diferenciam da anterior, pois prevalecem os interesses particulares nos acordos formais firmados 
entre as empresas. As franquias e as redes de licenciamento são exemplos conhecidos deste tipo de arranjo.

- Redes Proprietárias: caracterizam-se pela formalização de acordos relativos aos direitos de propriedade em ativos econômicos de posse dos acionistas das empresas envolvidas; elas podem ser classificadas em simétricas e assimétricas.

$>$ Redes Proprietárias Simétricas: são as joint ventures, geralmente empregadas na regulação de atividades como pesquisa e desenvolvimento, inovação tecnológica e sistemas de produção de alto conteúdo tecnológico.

> Redes Proprietárias Assimétricas: normalmente são encontradas em associações do tipo capital venture, separam o investidor de um lado e a empresa parceira do outro.

\subsubsection{Redes top-down e flexíveis}

Segundo Casarotto Filho e Pires (2001), as redes de empresas podem ser agrupadas em dois tipos: top-down e flexíveis.

- Redes top-down: são aquelas em que empresas de menor porte estabelecem relações de subcontratação, terceirização, parcerias, entre outras formas, para fornecerem sua produção e seus serviços a uma empresa centralizadora, ou também chamada, empresa-mãe. Na estratégia adotada nesta formulação, tanto a empresa principal quanto suas dependentes competem pela liderança de custo.

- Redes flexíveis: ocorre quando micro, pequenas e médias empresas se aliam para formarem um consórcio com objetivos em comum. Neste caso, as companhias conseguem se tornar competitivas no mercado por obterem uma boa relação entre flexibilidade e custo. 


\subsubsection{Organizações e Empresas Virtuais}

O conceito de empresas virtuais vem sendo amplamente discutido no atual contexto de globalização dos mercados e da produção. A velocidade e o volume de informações estimulam a criação de inovações e o surgimento de novas necessidades comerciais os quais as empresas tentam atender, mas que frequentemente não possuem todas as competências necessárias para lidar com estas demandas. Entretanto, combinando suas capacidades às competências complementares de outras empresas parceiras é possível desenvolver uma Empresa Virtual (EV).

Tanto que uma das formas de rede de empresas, descrita por Bremer (1996), é a empresa virtual que, do ponto de vista institucional, resulta da combinação das melhores competências essenciais de empresas legalmente independentes e, em termos funcionais, ela se mantém concentrada em competências coordenadas utilizando a tecnologia da informação (TI).

Camarinha-Matos e Afsarmanesh (2006) especificam mais a EV, para eles é uma aliança temporária de companhias que se unem para compartilhar habilidades e recursos a fim de responder eficazmente às oportunidades de negócios; tal cooperação é garantida por redes de computadores.

Já Amato Neto (2005, p.18) conclui, como Bremer, que uma empresa virtual deve ser analisada por dois pontos de vista: o funcional e o institucional.

Do ponto de vista institucional, a empresa virtual é a combinação das melhores competências essenciais de empresas legalmente independentes que cooperam entre si. São interligadas por tecnologia e cada membro tem acesso aos recursos existentes em toda rede. O risco de cada empreendedor é dividido entre os parceiros da rede (AMATO NETO, 2005, p.18).

Enquanto que, do ponto de vista funcional, uma característica é que essa concentração de competências essenciais (core competences) passa a ser coordenada de forma dinâmica e orientada para a solução de problemas, através de uma base de dados obtida pela integração da Tecnologia de Informação na execução do projeto (AMATO NETO, 2005, p.18).

Portanto, a EV pode ser configurada com o objetivo de produzir um produto específico, compartilhar recursos e instalações, prover um tipo particular de serviço, 
dividir riscos e custos; e, ao final, ela pode se dissolver naturalmente, permitindo que os parceiros encontrem novas oportunidades e novos aliados para explorar outras propostas (JAGDEV \& BROWNE, 1998, apud GOULART, 2000, p.21).

Contudo, apesar da EV ser composta por várias empresas diferentes, é fundamental gerenciar essa rede como se fosse uma só. Assim, segundo Byrne (1993, apud Goulart, 2000, p. 22), as principais características das Empresas Virtuais são:

a) Foco em Competências Essenciais: cada empresa participa com suas próprias habilidades, sendo essas complementares às das demais parceiras, assim, juntas tornam-se capazes de atender às demandas do mercado que não seriam possíveis se estivessem isoladas;

b) Direcionada a Oportunidade: a Empresa Virtual é um tipo de cooperação voltada a interesses comerciais. As empresas trabalham juntas para satisfazer uma oportunidade de negócio específica, separando-se após o fim desta. Cada EV é formada para explorar um projeto por vez;

c) Estrutura Organizacional Dinâmica e sem Hierarquia: a EV deve possuir regras adaptáveis que possam torná-la flexível a mudanças, formando uma estrutura organizacional dinâmica. Nesta aliança, os elementos que a compõem não devem dominar os demais, obtendo assim um maior grau de flexibilidade e horizontalidade nas decisões e ações;

d) Confiança: uma característica importante é o grau de confiança existente entre seus parceiros. A cultura baseada na vontade de partilhar habilidades e informações torna-se parte do processo. Assim arriscar e confiar são prérequisitos para participar de uma $\mathrm{EV}$;

e) Infraestrutura Tecnológica: a TI permite que empresas geograficamente distantes possam unir suas competências. Além de diminuir as fronteiras entre as empresas, essa infraestrutura ajuda a reduzir os custos de transação, produção e logística.

\subsubsection{Redes Colaborativas}

Uma rede colaborativa é constituída por um grupo de atores - podendo ser indivíduos isolados ou pertencentes a organizações -, em geral, são autônomos, 
estão espalhados geograficamente e tem valores heterogêneos, principalmente no que se refere a ambientes operacionais e culturas.

E diferentemente de outras redes, a colaboração deriva de uma crença compartilhada de que seus participantes conseguirão atingir objetivos que não seriam alcançados devido aos altos custos ou à falta de conhecimento em várias áreas de atuação, se fossem executados por apenas uma organização ou pessoa (CAMARINHA-MATOS E AFSARMANESH, 2006).

Assim, de acordo com Karvone et al. (2004), uma abordagem baseada em rede colaborativa visa dar mais eficiência às operações em proporção à sua escala econômica ou valorativa, balanceando custos e tempos investidos, assim como contribui para o acúmulo de conhecimento e a geração de inovação.

Por estas mudanças, Soares et al. (2003) creem que o paradigma das redes colaborativas muda a forma como as atividades comerciais, industriais e culturais são organizadas. Eles argumentam que, além da rápida evolução das cadeias de suprimentos tradicionais e das práticas de terceirização, atualmente existe uma tendência crescente para que as tarefas sejam executadas por equipes ou PMEs (pequenas e médias empresas), interligadas em redes. Estas equipes normalmente são formadas por arranjos temporários para executar algum projeto e se dissolverem quando as tarefas são concluídas (Camarinha-Matos e Afsarmanesh, 2004).

Portanto, as redes colaborativas podem emergir de várias formas e em diferentes domínios de aplicação, constituindo múltiplas facetas de um mesmo sistema e requerendo, desta forma, a contribuição de uma gama de disciplinas.

E de acordo com Camarinha-Matos e Afsarmanesh, (2004), várias manifestações de redes colaborativas surgiram nos últimos anos, como resultado dos desafios encontrados, tanto pela academia quanto pelo mundo dos negócios. Todavia, o estudo é um paradigma emergente e deve ser melhor avaliado ao longo do tempo.

\subsubsection{Síntese}

O desafio durante a elaboração do referencial teórico das alianças organizacionais foi a integração de vários conceitos sobre clusters regionais, arranjos produtivos 
locais, redes de cooperação entre empresas, redes interorganizacionais, redes topdown, redes flexíveis, organizações e empresas virtuais.

Por esta razão, o Quadro 1 apresenta uma síntese do material discutido no itém 2.2, com os principais tipos de aglomerados produtivos e redes de empresas.

\begin{tabular}{|c|c|}
\hline AUTOR & CONCEITO \\
\hline $\begin{array}{l}\text { AMATO NETO (2009) } \\
\text { ENRIGHT (1998) } \\
\text { COMISSÃO EUROPEIA (2002) } \\
\text { LASTRES et al. (2003) } \\
\text { SCHMITZ (1989) }\end{array}$ & $\begin{array}{l}\text { Cluster, Arranjo e Sistema Produtivo Local: são } \\
\text { caracterizados pela concentração geográfica de } \\
\text { empresas, de um mesmo setor ou de setores correlatos, } \\
\text { que tem em comum os ganhos de eficiência coletiva que } \\
\text { podem ser alcançados pela combinação de economias } \\
\text { externas e ações conjuntas. }\end{array}$ \\
\hline GRANDORI e SODA (1995) & $\begin{array}{l}\text { Redes Interorganizacionais: gestão de atividades } \\
\text { econômicas via interação interfirmas. } \\
\text { Redes Sociais: relações empresariais sem acordos } \\
\text { formais. } \\
\text { Redes Burocráticas: relacionamentos garantidos por } \\
\text { acordos formais e regras de conduta. } \\
\text { Redes Proprietárias: relações construídas por acordos } \\
\text { relativos. }\end{array}$ \\
\hline CASAROTTO e PIRES (1998) & $\begin{array}{l}\text { Redes Top-down:subcontratação, terceirização, } \\
\text { parcerias visando liderança de custo. } \\
\text { Redes Flexíveis: formação de alianças e consórcios } \\
\text { para aumentar sua competitividade. }\end{array}$ \\
\hline $\begin{array}{l}\text { AMATO NETO (2005) } \\
\text { JAGDEV e BROWNE (1998) } \\
\text { BYRNE (1993) }\end{array}$ & $\begin{array}{l}\text { Organizações e Empresas Virtuais: configuração com } \\
\text { o objetivo de produzir um produto/serviço, dividindo } \\
\text { custo/risco e depois se dissociando, permitindo novas } \\
\text { oportunidades a cada projeto. Pode ser compreendida } \\
\text { por meio de dois pontos de vistas: } \\
\text { Institucional: Combinação das melhores competências } \\
\text { essenciais de empresas legalmente independentes. } \\
\text { Funcional: concentração de competências essenciais } \\
\text { coordenadas por uma base de dados criada pela } \\
\text { tecnologia de informação. }\end{array}$ \\
\hline $\begin{array}{l}\text { CAMARINHA-MATOS e } \\
\text { AFSARMANESH (2006) } \\
\text { KARVONE et al. (2004) } \\
\text { SOARES et al. (2003) }\end{array}$ & $\begin{array}{l}\text { Redes colaborativas: constituída por um grupo de } \\
\text { atores - podendo ser indivíduos isolados ou } \\
\text { pertencentes a organizaçốes - visa dar mais eficiência } \\
\text { às operações em proporção à sua escala econômica ou } \\
\text { valorativa, balanceando custos e tempos investidos, } \\
\text { assim como contribui para o acúmulo de conhecimento e } \\
\text { a geração de inovação. }\end{array}$ \\
\hline
\end{tabular}

Quadro 1 - Síntese do referencial teórico dos aglomerados produtivos e redes empresariais Fonte: Autora (2012) 
Esta seção do referencial teórico tem importância neste trabalho, pois os fundamentos aqui apresentados servem como base para caracterizar o tipo de aglomerado produtivo identificado nos estudos de caso analisados.

\subsection{SUSTENTABILIDADE}

O meio ambiente sempre foi a base de desenvolvimento da vida e das atividades humanas, dele o homem obtém matéria-prima para alimentação, abrigo, vestuário, bens de consumo, entre outros, sem mencionar a água e o ar, essenciais para a sua sobrevivência.

A interação entre os sistemas ambientais e os sistemas humanos (economia, política, cultura, etc.) sempre foi constante, acarretando neles uma relação de causa-efeito; as ações humanas provocam uma mudança ambiental que influencia na valorização desta natureza transformada por eles mesmos. Dessa maneira, é inegável que desde o início da civilização o ambiente terrestre sofre alterações com as atividades desenvolvidas pelo homem.

Só que em algum momento da história, o equilíbrio que havia entre o consumo humano e a capacidade de reposição da natureza se rompeu, e o meio ambiente tem sofrido graves alterações que passaram a comprometer a qualidade de vida na Terra.

Nos últimos 60 anos, o mundo vem debatendo com maior ênfase as questões relacionadas às pessoas, às empresas, aos negócios e ao planeta. Isto faz com que o termo Sustentabilidade esteja agora em foco nos meios empresariais, governamentais, acadêmicos e na sociedade, de maneira geral.

Pelas discussões, percebe-se um crescimento no interesse destes atores em participar na resolução deste assunto tão vasto. Diversos pontos - como consumo e manipulação de fontes hídricas, eficiência enérgica, mudanças climáticas, emissões de gases de efeito estufa (GEE), tratamento de resíduos, responsabilidade social, trabalho escravo, transparência das informações, desigualdade social, cultura consumista e consumo consciente, etc. -, estão em constante debate, pois as tendências atuais de produção e consumo são insustentáveis, sendo preciso 
revertê-las para "garantir os recursos para sustentar esta e as próximas gerações". (BRUNDTLAND, 1991, p.47).

O desenvolvimento mundial proporcionou problemas sociais, ambientais e econômicos; e nossa forma moderna de pensar foi moldada nas tradições mecanicistas de Descartes e Newton, sendo essa abordagem inadequada para solucionar os principais problemas do mundo atual (CAPRA, 2004).

Diante deste desequilíbrio, diversos manifestos, estudos, pesquisas e fóruns foram desenvolvidos ao longo dos anos evidenciando os problemas existentes e propondo novas soluções para o crescimento sustentável da sociedade.

A partir das informações acima, nota-se que o termo sustentabilidade vem atrelado a princípios éticos como respeito, transparência, honestidade e solidariedade, e entendido como um conceito holístico e sistêmico, no qual é preciso estar atento a aspectos econômicos, sociais, culturais e ambientais da sociedade humana e do meio ambiente para que se criem métodos viáveis para que essas relações continuem a existir.

Com base nisto, esta mudança de postura pode interferir nos resultados imediatos e a longo prazo, por isso a busca por novas formas de fazer negócios e de se relacionar no espaço em que se vive tentando atingir valores diferenciados do mercado atual. E por consequência, um modelo de desenvolvimento sustentável deve objetivar o atendimento das necessidades presentes na sociedade, sem, contudo comprometer a possibilidade de gerações futuras satisfazerem suas próprias necessidades (AMATO NETO, 2011, p. 2). Para que isso ocorra é preciso que se trabalhe para promover prosperidade econômica, qualidade ambiental e igualdade social.

\subsubsection{A sustentabilidade nas empresas}

Uma empresa pode aderir à sustentabilidade por diversos fatores motivadores como a conveniência, a consciência ou o constrangimento. A questão, além dos fatores motivadores, é que o tema sustentabilidade está presente na agenda das principais instituições, nas mídias e no discurso dos executivos de diversas linhas de atuação, 
O volume de informações, a diversidade de abordagem, indicadores e ferramentas, juntamente com o relato de casos de sucesso divulgados confundem o executivo sobre o que é sustentabilidade e como ele deve agir. É comum as organizações sentirem-se pressionadas a fazer ações relacionadas ao tema, sem ter a clareza do que deve ser feito e como deve ser feito.

A busca por um posicionamento diferenciado ou de um estágio avançado em sustentabilidade desafia os executivos, pois estes percebem que iniciativas de responsabilidade social e adoção de política ambiental para se adequar às leis e exigências regulatórias são necessárias, mas não são suficientes.

As organizações buscam diretrizes maiores, adotando ou aderindo às abordagem baseadas em princípios mundiais como: Triple Bottom Line e The Natural Step; e ferramentas como: indicadores Ethos e GRI. Essas diretrizes promovem um alinhamento de intenções, mas não são suficientes para suportar o desenvolvimento sustentável.

Nas próximas subseções estão descritos os conceitos, abordagens e ferramentas de suporte que as organizações devem ter disseminadas em sua estrutura para promover a sustentabilidade.

\subsubsection{Desenvolvimento Sustentável: Linha do Tempo}

O conceito de desenvolvimento sustentável foi definido pela primeira vez no relatório Nosso futuro comum: Comissão Mundial sobre o Meio Ambiente e Desenvolvimento. (BRUNDTLAND, 1991), de acordo com ele é o "desenvolvimento que atende as necessidades do presente sem comprometer a capacidade das futuras gerações de atenderem as suas próprias necessidades".

Para complementar esta definição é apresentada uma linha do tempo, representada nas figuras 3, 4 e 5, com os marcos relevantes sobre o tema na história, como os principais manifestos e fóruns, que auxiliam na compreensão dos desafios da construção de um conceito de desenvolvimento sustentável a nível mundial.

A figura 3 mostra o período entre 1945 e 1989, e em seguida foi feito um resumo dos órgãos e seus papeis na luta por essa nova forma de desenvolvimento. 


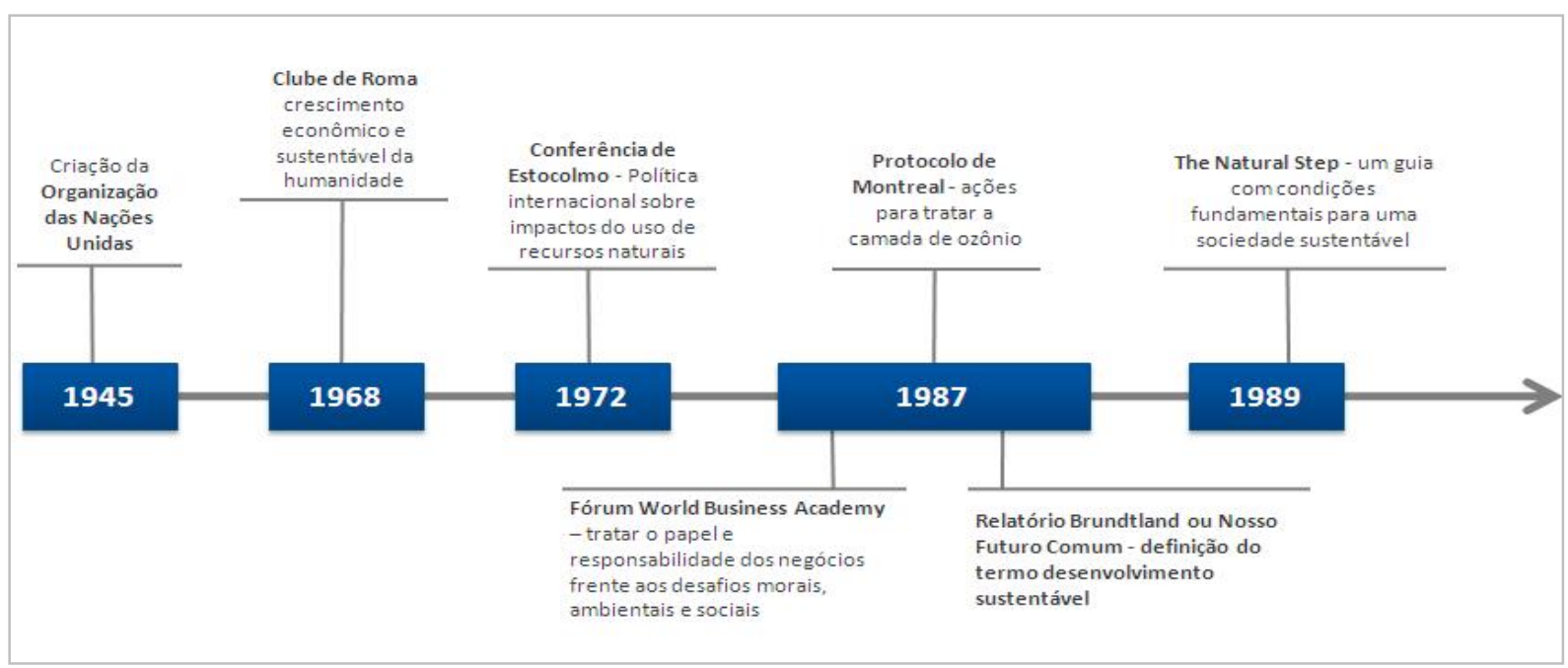

Figura 3 - Desenvolvimento Sustentável - Linha do tempo 1945-1989

Fonte: Autora (2012)

A Organização das Nações Unidas, ONU, foi fundada em 1945 na cidade de São Francisco, EUA, com o intuito de ser uma organização constituída por governos da maioria dos países do mundo; seu objetivo principal é criar e colocar em prática mecanismos que possibilitem a segurança internacional, desenvolvimento econômico, definição de leis internacionais, respeito aos direitos humanos e progresso social.

Somente 23 anos depois é criado o Clube de Roma, que reúne pessoas em cargos de influência em seus respectivos países, com o apoio delas visa promover um crescimento econômico estável e sustentável da humanidade, pois entre seus membros principais há cientistas - inclusive alguns condecorados com o prêmio Nobel -, economistas, políticos, chefes de estado e até mesmo associações internacionais.

Em 1972, tem início a Conferência sobre o Meio Ambiente Humano em Estocolmo. Deste encontro surgiu o Programa das Nações Unidas para o Meio Ambiente (PNUMA), cujo objetivo é coordenar as ações internacionais de proteção ao meio ambiente e de promoção do desenvolvimento sustentável.

Quinze anos mais tarde foi publicado o relatório pioneiro Nosso Futuro Comum, Relatório de Brundtland, que recebeu este nome em homenagem a Gro Brundtland - na época, presidente da Comissão Mundial sobre o Meio Ambiente e Desenvolvimento.

Também neste ano foi elaborado o Protocolo de Montreal sobre substâncias que afetam e/ou destroem a camada de ozônio. É um tratado internacional em que os 
países signatários se comprometeram a substituir substâncias nocivas à camada, pois estas estariam reagindo com o ozônio $\left(\mathrm{O}_{3}\right)$ na parte superior da estratosfera, destruindo-a.

Ainda em 1987, foi fundada a World Business Academy, um fórum para tratar do papel e da responsabilidade dos negócios frente aos desafios morais, ambientais e sociais.

Dois anos mais tarde, surge na Suécia The Natural Step (TNS), um guia que alicerça a implantação de uma sociedade sustentável, escrito a partir de um consenso entre cientistas e apresentando uma metodologia para o planejamento de negócios e tomadas de decisão. Esse material foi destinado a empresas, organizações e pessoas que desejam contribuir para o desenvolvimento sustentável da sociedade.

A seguir a linha do tempo de 1990 a 2002 (Figura 4), com novas preocupações, confrontos e alianças.

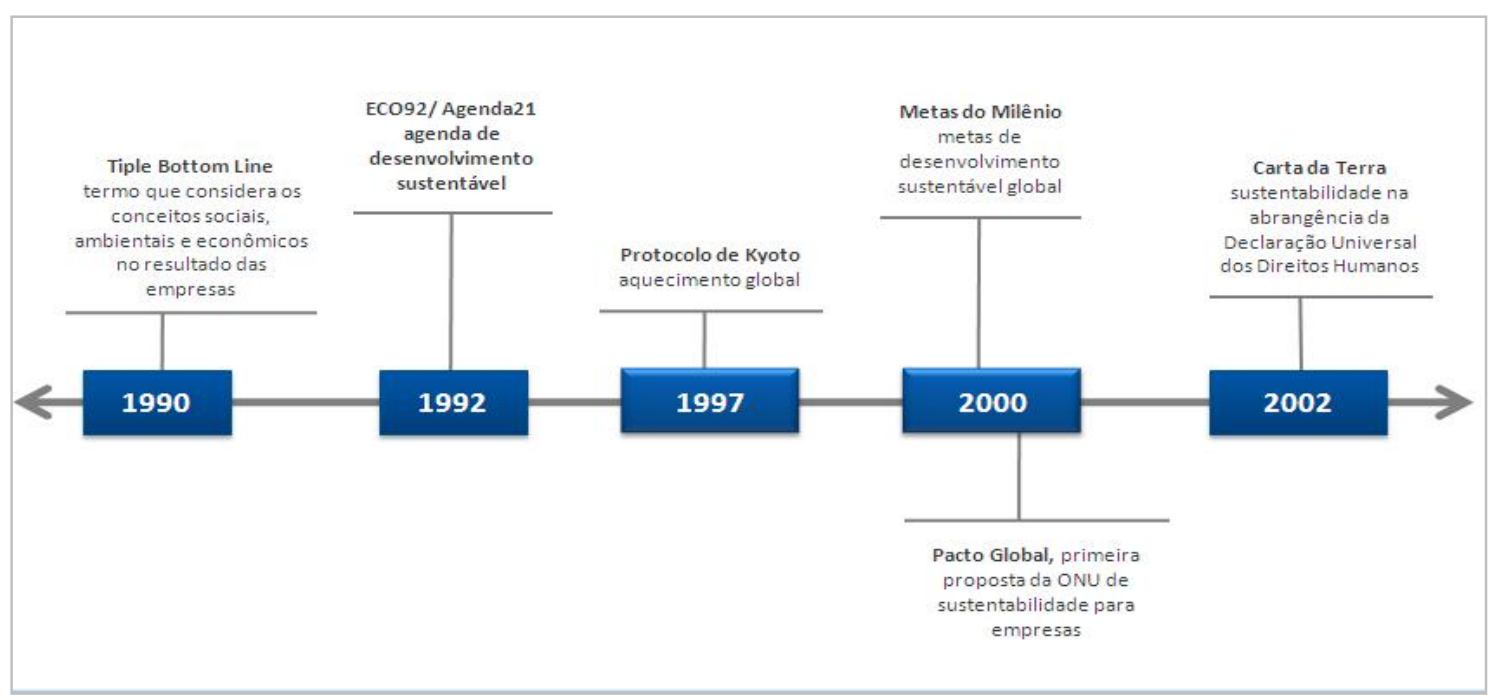

Figura 4 - Desenvolvimento Sustentável - Linha do tempo 1990-2002 Fonte: Autora (2012)

Em 1990, foi criado pela consultoria SustainAbility o termo Triple Bottom Line, que representa a expansão do tradicional modelo de negócios para um novo, este leva em consideração a performance ambiental e social da companhia, além da financeira.

Dois anos depois, a Confederação das Nações Unidas sobre o Meio Ambiente e o Desenvolvimento (CNUMAD), conhecida como ECO-92, é realizada no Rio de Janeiro. Neste evento foi elaborada a Agenda 21, um plano abrangente sobre os 
problemas mundiais envolvendo medidas globais, regionais e locais, este tratado foi ratificado por 178 países membros da ONU.

Em 1997, foi assinado o Protocolo de Kyoto no seio da Convenção Quadro das Nações Unidas sobre Mudanças Climáticas. Ele se refere ao aquecimento global e às mudanças climáticas causadas pelas atividades humanas nos últimos séculos, envolvendo, principalmente, a queima de combustíveis fósseis, com consequências extremamente relevantes para os seres humanos e as demais formas de vida na Terra.

Isto levou a primeira proposta da ONU tratando do tema sustentabilidade para as empresas, o Pacto Global, lançado em 2000, por uma iniciativa pessoal do então secretário-geral Kofi Annan; este acordo visava demonstrar a face humana da globalização.

Neste mesmo ano, durante a Cúpula do Milênio, realizada em Nova lorque, foram listados seis assuntos fundamentais às relações internacionais: liberdade, igualdade, solidariedade, tolerância, respeito pela natureza e senso de responsabilidade comum. Demonstrando pelas Metas do Milênio que os dezoito objetivos vinculados às oito metas relacionam desenvolvimento sustentável global à necessidade de novas configurações nas relações sociais.

Por isso, em 2002, em Johanesburgo, na África do Sul, a Carta da Terra foi aprovada pela ONU na Cúpula Mundial sobre o Desenvolvimento Sustentável. Este documento busca a mesma abrangência da Declaração Universal dos Direitos Humanos, no que se refere à sustentabilidade, equidade e justiça social.

A próxima figura refere-se ao período de 2007 a 2012, no qual predomina a renegociação de compromissos anteriores e a preocupação com o clima e as emissões de gases de efeito estufa.

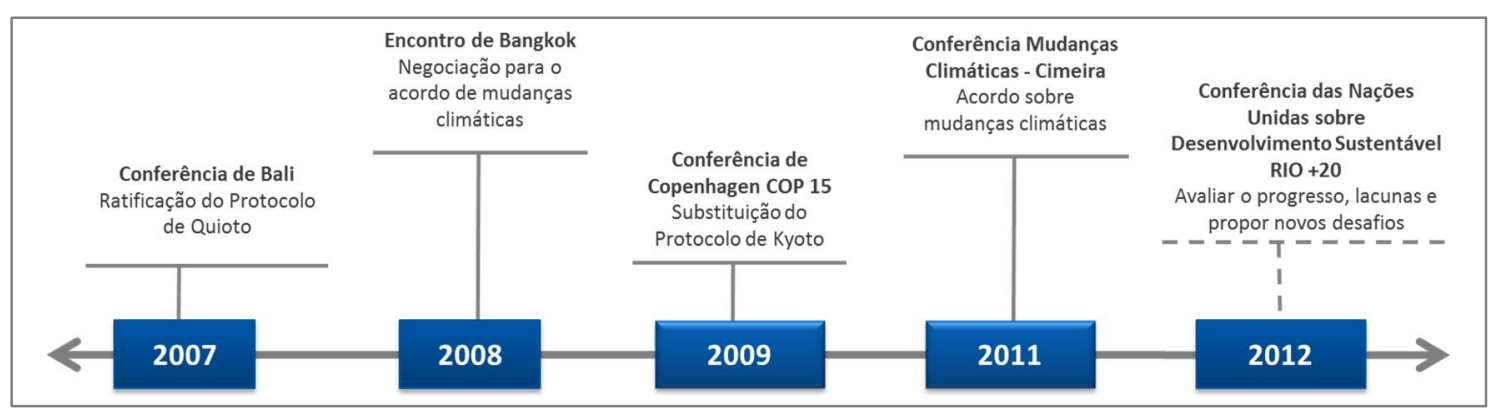

Figura 5 - Desenvolvimento Sustentável - Linha do tempo 2007-2012

Fonte: Autora (2012) 
Em 2007, ocorreu em Bali, a Conferência das Nações Unidas sobre Mudanças Climáticas (COP-13), com o intuito de criar um sucessor do Protocolo de Kyoto; contendo metas mais ambiciosas e sendo mais exigente no que diz respeito às alterações climáticas.

No ano seguinte, aconteceu o Encontro de Bangkok, que abriu as negociações para um acordo global mais eficiente de combate às mudanças climáticas que seria discutido na COP-15.

Desta forma, em 2009, a Conferência Climática COP-15 foi realizada em Copenhagen. E teve como objetivo estabelecer um tratado que substituísse 0 Protocolo de Kyoto, vigente de 2008 a 2012. Este evento resultou em uma carta de intenções, concluído e assinado por 20 chefes de Estado que se comprometeram a limitar, de maneira voluntária, o aquecimento global, sem estabelecer metas.

Em 2011, ocorreu a 16 ${ }^{\text {a }}$ Conferência sobre Mudanças Climáticas, ou Cimeira, em Cancun, no México. Foi finalizado com um acordo modesto que não fixou metas vinculativas de redução de emissões de gases de efeito de estufa - para países ricos ou pobres - mas determinou em ${ }^{\circ} \mathrm{C}$ o limite para o aumento da temperatura média global até o final do século. Em relação ao prolongamento do Protocolo de Kyoto, um dos temas polêmicos da conferência, os países comprometeram-se a concluir este objetivo o mais rápido possível, para não existir um hiato entre o primeiro e o segundo período de cumprimento do plano de reduções de GEE, já que o primeiro terminou em 2012.

Em junho de 2012 houve a Conferência das Nações Unidas sobre Desenvolvimento Sustentável, batizada de Rio +20 , pois marca o 20aniversário da Conferência das Nações Unidas sobre Meio Ambiente e Desenvolvimento, ocorrida na cidade do Rio de Janeiro em 1992. O objetivo desta convenção era assegurar um comprometimento político renovado para o desenvolvimento sustentável, avaliar o progresso feito até o momento e fechar as lacunas que ainda existiam na implementação dos resultados dos principais encontros sobre desenvolvimento sustentável, além de abordar novos desafios emergentes... 


\subsubsection{Abordagens para sustentabilidade}

As abordagens para sustentabilidade auxiliam as organizações a trilhar o caminho sustentável. Contribuem para o planejamento e priorização de ações de acordo com a visão de sucesso construída a longo prazo.

\subsubsection{Triple Bottom Line}

O termo triple bottom line foi criado em 1994 por John Elkington, fundador de uma consultoria britânica chamada SustainAbility. Seu argumento era que as empresas deveriam estabelecer três diferentes formas de controle. Uma delas é a medida tradicional de lucro das empresas - o bottom line, resultado final, da conta entre perdas e ganhos. A segunda é a linha das pessoas e dos atores envolvidos ao longo de suas operações, ou seja, o lado social do balanço. A terceira compete ao que é feito ou não pelo planeta, mensurando quanto ambientalmente responsável a empresa é.

Portanto, o triple bottom line (TBL), consiste em três P's: lucro (profit), pessoas (people) e planeta (planet). E tem como objetivo medir o desempenho financeiro, social e ambiental de uma organização durante um período de tempo. Somente uma empresa que se norteia pelo TBL considera todos os custos envolvidos na realização de negócios, atingindo seu próprio valor sustentável. 


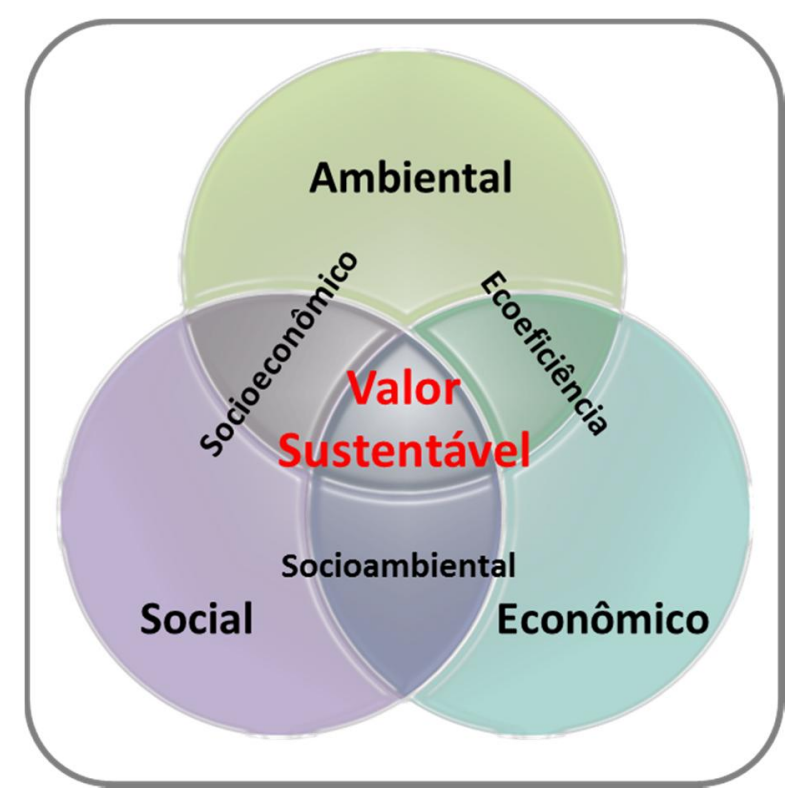

Figura 6 - Triple Bottom Line

Fonte: SustainAbility (1997)

Assim, o triple bottom line, conhecido como os 3 Ps (People, Planet and Profit, ou, em português, PPL: Pessoas, Planeta e Lucro) representa:

a) People: capital humano de uma organização ou sociedade e as variáveis desta relação, como salários justos, adequação à legislação trabalhista e ambiente de trabalho agradável. Também é imprescindível atentar para os efeitos da atividade econômica nas comunidades vizinhas ao empreendimento.

b) Planet: relacionado ao capital natural de uma companhia e seus resultados na sociedade. É o alicerce ambiental do tripé. Neste item é importante pensar nos efeitos das ações a pequeno, médio e longo prazo. Porque, a princípio, praticamente toda atividade econômica tem impacto ambiental negativo. Nesse aspecto, a empresa ou sociedade deve projetar formas de amenizá-lo e/ou compensá-lo. Para tanto, deve-se estar atento as negociações e adequar-se à legislação ambiental, além de se preocupar com as pegadas de carbono (ver item 2.3.3.9) geradas por seus processos produtivos.

c) Profit: É resultado econômico positivo de uma empresa, o lucro. Para obter credibilidade dos demais atores sociais e permanecer no mercado, essa coluna do tripé deve levar em conta as outras duas que a sustentam. 
Mas, alguns pesquisadores atuais avaliam que a abordagem realizada pelo Triple Bottom Line não é completa, pois é necessário olhar para os três pilares num contexto mais abrangente, considerando a visão sistêmica (conceito que será abordado na seção 2.3.2.3).

Mesmo assim, ao considerar que estes três pilares estão contidos em um universo, e que devem ser trabalhados em equilíbrio, qualquer alteração ou preferência por um dos alicerces pode provocar consequências desastrosas nos demais e principalmente na organização que o utilizou.

\subsubsection{The Natural Step - TNS}

Segundo Robert (2002), pode-se definir The Natural Step da seguinte forma:

The Natural Step (TNS) é uma abordagem científica e sistêmica do planejamento organizacional para a sustentabilidade. Oferece um conjunto prático de critérios de planejamento que pode ser usado para orientar determinada ação para o alcance da sustentabilidade. Baseia-se fundamentalmente em uma avaliação integrada da situação atual em que se pretende atuar e na determinação da visão futura de sucesso por meio de uma metodologia chamada backcasting. (ROBERT, 2002)

Desta maneira, o TNS avalia a sustentabilidade em níveis independentes, nos planos ambiental, social e econômico, pois acredita que a análise do sistema vai além das três instâncias juntas.

Para tanto, a abordagem traz quatro condições essenciais para implementar a sustentabilidade e sugere uma metodologia de planejamento para alcançá-los denominada backcasting.

Diferentemente do planejamento estratégico tradicional, que procura antever tendências traçando cenários possíveis e ajustando os planos de gestão, esta técnica parte da definição dos objetivos finais (o que seria um negócio sustentável) para então começar a traçar as estratégias organizacionais que devem atingi-lo.

Isto posto, a definição das quatro condições sistêmicas essenciais para a manutenção da vida na Terra, junto com uma metodologia ampla sobre como aplicá- 
las estrategicamente, estão na estrutura do TNS. Destarte, existem três componentes importantes para sua composição:

- Funil: o TNS usa uma ferramenta simbólica para ilustrar o atual quadro ambiental e a margem de manobra disponível. Com isso, a situação das pessoas na Terra pode ser vista como um funil com cada vez menos espaço para agir. Essa situação advém dos mecanismos que fornecem recursos essenciais à vida - e que possibilitam a existência da sociedade, como ar puro, água limpa e solo fértil —, pois estes estão em declínio. Ao mesmo tempo que a demanda da sociedade por tais recursos e serviços está aumentando.

- Condições do Sistema: são princípios fundamentais, ou condições essenciais, usadas para direcionar as organizações rumo a sustentabilidade. São eles:

Princípio 1: Em uma sociedade sustentável não pode ocorrer aumento sistêmico da concentração de materiais extraídos da crosta terrestre.

Princípio 2: Em uma sociedade sustentável não pode ocorrer aumento sistêmico de substâncias produzidas pela sociedade.

Princípio 3: Em uma sociedade sustentável não pode ocorrer aumento sistêmico da degradação de ecossistema por meios físicos.

Princípio 4: Em uma sociedade todo ser humano deve ter suas necessidades básicas atendidas.

- Estratégia de implementação: O TNS criou e testou ferramentas específicas, desenvolvidas para incorporar a sustentabilidade no planejamento estratégico e nos processos decisórios de organizações complexas, trata-se do planejamento ABCD, que estabelece as ações desenvolvidas a cada etapa, são elas:

A) Definir sustentabilidade, pois é preciso entender o sistema a ser implantado;

B) Realizar análise da realidade atual da organização;

C) Criar visão de futuro e as ações para alcançá-la;

D) Traçar planos de ação e definir prioridades. 
Reconhecendo o valor dos modelos sustentáveis, companhias de grande porte trabalham para sair de sua visão linear e migrar para um modelo holístico, revisando conceitos e comportamentos que antes eram naturais; afinal dar destino correto ao lixo, conhecer os atores a sua volta e qual o grau de poder de sua relação, entre outras ações, torna-se parte do processo. Contudo, este não é um processo feito só em empresas, basta saber que atualmente, na Suécia, The Natural Step tem transformado a forma com que indivíduos, escolas, comunidades, além das companhias, pensam a sustentabilidade.

\subsubsection{Visão Sistêmica}

Para Fuller (1969, apud Wayne, 2012, p.35), a especialização nos negou a capacidade de enxergar o sistema todo, na medida em que não conseguimos compreender como diferentes compartimentos de conhecimentos se interrelacionam. Por consequência, a superespecialização pode levar a extinção do conhecimento, uma vez que perdemos nossa capacidade de pensar de forma abrangente e de nos adaptarmos às mudanças.

E justamente o pensamento sistêmico representa uma mudança no paradigma da especialização. Ao construir novas formas de ação que permitam não só lidar de forma eficiente com situações emergentes e inesperadas, como também integrar as informações em redes mais amplas de relações e permitir a realização de trabalhos em parcerias, ampliando as competências disponíveis em um projeto.

Desta forma, a ciência sistêmica mostra que os sistemas não podem ser compreendidos por meio de análise individual. As propriedades das partes não são necessariamente atributos extrínsecos, superficiais, mas precisam ser vistos e entendidos dentro do contexto em que estão inseridos. Nessa perspectiva, o pensamento cartesiano, o pensamento holístico e o pensamento sistêmico, apesar de cada qual possuir uma identidade, método e história diferentes, não são diametralmente opostos, apenas representam caminhos diferentes, visando chegar a algo comum, ao buscar a verdade do todo (CAPRA, 2004). 


\subsubsection{Ferramentas de suporte para sustentabilidade}

Ferramentas para gestão e alinhamento das iniciativas voltadas para a estratégia sustentável das empresas.

\subsubsection{Global Reporting Initiative - GRI}

O GRI, criado em 1998, é um guia de princípios e indicativos que orienta na divulgação da performance econômica, social e ambiental de uma organização.

Ele tem por objetivo tornar padrão a prática de reportar as ações sustentáveis e assessorar as instituições na confecção de seu relatório anual de sustentabilidade, comunicando o desempenho dos principais indicadores GRI pertinentes ao negócio. Logo, o produto final obtido por esta ferramenta é o relatório anual de sustentabilidade, formatado para atender os diversos públicos de interesse.

\subsubsection{2 Índice de Sustentabilidade Empresarial - ISE}

Esse índice foi criado em dezembro de 2005 pela BM\&FBovespa e formulado com base no conceito internacional do Triple Bottom Line.

O ISE é uma ferramenta de análise comparativa da performance das empresas listadas na bolsa de valores de São Paulo pelo viés da sustentabilidade corporativa, tanto que possui uma carteira composta por ações de cerca de 40 empresas com bons desempenhos nas três dimensões avaliadas (econômica, social e ambiental).

Pela adesão das companhias e dos investidores, suas metas são: se tornar referência, benchmark, para o investimento socialmente responsável, atuar como indutor de boas práticas no meio empresarial brasileiro e promover a transparência da instituição e das empresas participantes gerando credibilidade no mercado local e mundial. 


\subsubsection{Dow Jones Sustainable Index}

Lançado em 1999, este é o primeiro indicador financeiro de sustentabilidade global. Este índice possui grande credibilidade no mercado, pois as empresas que constam em sua lista são classificadas como as mais capazes de criar valor para os acionistas, a longo prazo. Assim sendo, com este indicador, os investidores e o mercado podem avaliar o equilíbrio entre retorno financeiro e atuação ética.

\subsubsection{Indicadores Ethos}

Desenvolvidos com o propósito de oferecer às empresas uma ferramenta de gestão para o diagnóstico e planejamento das práticas de responsabilidade social empresarial, estão disponíveis desde 1999 e são atualizados ao longo dos anos.

Trata-se de um instrumento de uso essencialmente interno, que permite a autoavaliação da administração no que diz respeito às ações sustentáveis ocorridas dentro da instituição. Esses indicadores abrangem os seguintes temas: valores, transparência e governança, público interno, meio ambiente, fornecedores, consumidores e clientes, comunidade, governo e sociedade.

\subsubsection{Instituto Brasileiro de Análises Sociais e Econômicas - IBASE}

O balanço social é um demonstrativo publicado anualmente por uma empresa reunindo suas informações sobre os projetos, benefícios e ações sociais dirigidas aos empregados, investidores, analistas de mercado, acionistas e à comunidade, sendo também um instrumento estratégico para avaliar e multiplicar o exercício da responsabilidade social corporativa.

No Brasil, a ideia começou a ser discutida na década de 1970. Contudo, apenas nos anos 1980 surgiram os primeiros balanços sociais empresariais. E foi a partir da 
década de 1990 que corporações de diferentes setores passaram a publicá-los anualmente.

A proposta, no entanto, só ganhou visibilidade nacional quando o sociólogo Herbert de Souza, o Betinho, lançou, em junho de 1997, uma campanha pela divulgação voluntária do balanço social.

\subsubsection{6 Índice de Carbono Eficiente - ICO2}

Criado em 2010, é uma ação conjunta da BMF\&Bovespa e do BNDES. Trata-se de um indicador composto pelas ações participantes do índice IBrX-50 (índice constituído pelas 50 ações mais negociadas da BM\&FBOVESPA) atreladas às taxas de emissões de GEE dessas empresas .

A ponderação da composição do indicador é baseada nas receitas brutas das companhias e suas emissões de GEE. Ou seja, em uma comparação setorial, quanto maior for as emissões em relação à receita, maior será a perda de participação da empresa no índice.

Buscando minorar os impactos ambientais, além de divulgar os volumes de emissões, as empresas podem disponibilizar no site da BM\&FBOVESPA seus inventários detalhados, assim como suas iniciativas e projetos de redução de emissões de GEE.

\subsubsection{Carbon Disclosure Project - CDP}

Criada em 2000, é uma organização independente, sem fins lucrativos e que detém o maior banco de dados sobre impacto climático corporativo do mundo.

É a principal iniciativa do setor financeiro para mitigar as mudanças climáticas. $\mathrm{O}$ objetivo é estabelecer relações entre acionistas e empresas orientadas por oportunidades de negócio decorrentes do aquecimento global. Trata-se de um requerimento coletivo e um questionário - formulado por investidores institucionais e 
endereçado às empresas listadas nas principais bolsas de valores do mundo visando obter e divulgar informações sobre as políticas de mudanças climáticas adotadas pelo mercado financeiro. Em 2007, a CDP publicou os dados de emissões de 2400 das maiores empresas globais, responsáveis por $26 \%$ da emissão global de GEE.

O CDP atua nas 3000 maiores corporações do mundo para ajudá-las a demonstrar que uma redução efetiva nas emissões de carbono pode ser feita conjuntamente com suas atividades produtivas.

\subsubsection{Water Disclosure Project - WDP}

Instituído em 2009 pelo mesmo grupo que rege o Carbon Disclosure Project.

Seu objetivo é aumentar a plataforma de dados do CDP, por isso, recolhe informações relacionadas ao uso da água, como exposição potencial a estresse hídrico ${ }^{3}$ e uso sustentável do recurso.

\subsubsection{Pegada ecológica ou Pegada de carbono}

A pegada ecológica de um país, de uma cidade ou de uma pessoa, corresponde ao tamanho das áreas produtivas terrestres e marítimas necessárias para gerar produtos, bens e serviços que sustentem nosso estilo de vida. Em outras palavras, a pegada de carbono é uma forma de traduzir, em hectares (ha), a extensão de território que uma pessoa ou toda uma sociedade "utiliza", em média, para se manter.

No entanto, este conceito, criado em 1996, também simboliza uma ferramenta de leitura e interpretação da realidade, pela qual se pode enxergar, ao mesmo tempo, problemas conhecidos - como a desigualdade social e a cultura consumista -, e, ainda, a construção de novos caminhos para solucioná-los, por meio de uma

\footnotetext{
${ }^{3}$ Estresse hídrico: está relacionado às necessidades mínimas de água per capita para manter uma qualidade de vida adequada em regiões áridas.
} 
distribuição mais equilibrada dos recursos naturais e pelo consumo consciente, que exigem mudanças de posturas e atitudes das organizações e governos, mas também de cada indivíduo.

\subsection{PROJETOS COLABORATIVOS DE SUSTENTABILIDADE}

Para Capra (2004), a emergência de crises sociais, ecológicas e econômicas enfrentadas pelo mundo, embora sejam desafios bem distintos, possuem as mesmas dinâmicas subjacentes. Isto porque os problemas são sistêmicos e qualquer abordagem limitada a um enfoque não colaborativo entre as partes, apenas deslocará o problema para dentro da teia de inter-relacionamentos. Logo, a solução só poderá ser encontrada se a própria estrutura for modificada.

Esta visão mais ampla é característica do pensamento sistêmico, como defende Capra (2004): "a teoria dos sistemas vê o mundo em termos de inter-relação e interdependência de todos os fenômenos, e nesse arcabouço denomina-se sistema um todo integrado, cujas propriedades não podem ser reduzidas a partes específicas. Organismos vivos, sociedades e ecossistemas são todos sistemas".

Desta forma, o estabelecimento de redes de colaboração entre organizações para execução de projetos de aplicação de sustentabilidade sai da especialização para formar um sistema, pois permite que um conjunto de organizações se entrelace através de relacionamentos formais ou comerciais, mesmo não estando na mesma área geográfica, pois buscam o desenvolvimento de soluções em conjunto. Ou seja,

o envolvimento de diversas organizações pela busca da solução em conjunto proporciona o desenvolvimento de um sistema. 


\subsubsection{Síntese}

TBL, TNS e Visão Sistêmica são abordagens que auxiliam no entendimento do sistema e fornecem subsídios para criar estratégias de desenvolvimento sustentáveis bem sucedidas.

Mas elas precisam sair do campo teórico e serem transformadas em ações para que se alcance o objetivo almejado. Por isso, a execução e o detalhamento destas tarefas podem ser estruturadas por indicadores e ferramentas de medição, acompanhamento e controle (por exemplo: ISO, GRI, ISE, CDP, ICO2, etc.).

Assim, para realizar a integração dos conceitos, abordagens e ferramentas descritos nos tópicos anteriores foi elaborado o Quadro 2, no qual se faz uma síntese do referencial teórico discutido na seção Sustentabilidade.

A prática destes conceitos será verificada nos estudos de casos analisados neste trabalho, através do questionário de entrevista.

\begin{tabular}{|l|l|}
\hline \multicolumn{1}{|c|}{ AUTOR } & \multicolumn{1}{|c|}{ CONCEITO } \\
\hline $\begin{array}{l}\text { Sistema } \\
\text { Capra (1986) } \\
\text { Fuller (1969) }\end{array}$ & $\begin{array}{l}\text { Visão Sistêmica: } \\
\text { Entender o sistema: o ambiente a sua volta e o contexto em } \\
\text { que ele está inserido. }\end{array}$ \\
\hline $\begin{array}{l}\text { Abordagem } \\
\text { SustainAbiliy (1995) }\end{array}$ & $\begin{array}{l}\text { Triple Bottom Line: } \\
\text { People, Planet e Profit. } \\
\text { Robert (2002) }\end{array}$ \\
\hline $\begin{array}{l}\text { The Natural Step: } \\
\text { Abordagem científica e sistêmica. }\end{array}$ \\
\hline Ferramentas & $\begin{array}{l}\text { GRI - Global Repoting Initiative } \\
\text { ISE - Índice de Sustentabilidade Empresarial } \\
\text { DJSI - Dow Jones Sustainable Index } \\
\text { Indicadores Ethos } \\
\text { IBASE - Inst. Brasileiro de Análise Sociais e Econômicas } \\
\text { ICO2 - Índice de Carbono Eficiente } \\
\text { CDP - Carbon Disclosure Project } \\
\text { Pegada Ecológica }\end{array}$ \\
\hline
\end{tabular}

Quadro 2 - Referencial teórico sobre sustentabilidade Fonte: Autora (2012) 


\section{MÉTOdOS CIENTÍFICOS}

\subsection{A PESQUISA CIENTÍFICA}

A pesquisa é um conjunto de ações, propostas para encontrar a solução para um problema. É desenvolvida aplicando conhecimentos disponíveis, teorias, técnicas e procedimentos científicos e, requerida quando não se dispõem de informação suficiente para responder a um determinado questionamento. Cervo e Bervian (2002, p.63) concordam com isto, pois a definem como "uma atividade voltada para a solução de problemas teóricos ou práticos, com o emprego de processos científicos" que incluem métodos e ferramentas utilizados no processo de investigação.

Contudo, para Gil (2002, p.17), a pesquisa tem um caráter pragmático, é "um procedimento racional e sistemático que tem como objetivo proporcionar respostas aos problemas que são propostos".

Já Silva e Menezes (2005, p.9) parecem discordar desse mecanismo lógico e preciso ao afirmarem que a pesquisa é um trabalho em andamento, cujas variáveis nem sempre são controláveis ou previsíveis. Ainda mais quando envolve pessoas, como no caso desta dissertação. Então, adotar uma metodologia significa escolher um caminho, um percurso global em busca de uma resposta. No entanto, a jornada, muitas vezes, requer a reinvenção, desconstrução ou adaptação a cada etapa. "Precisamos, então, não somente de regras e sim de muita criatividade." (Silva e Menezes, 2005, p.9).

Assim, este capítulo tem por objetivo descrever os seguintes aspectos do presente trabalho: classificação da pesquisa, universo da pesquisa, instrumentos de coleta de dados e análise dos dados. 


\subsection{CLASSIFICAÇÃO DA PESQUISA}

Baseado na proposta de Silva e Menezes (2005, p.20) a disposição desta pesquisa está dividida em quatro grandes áreas: natureza da pesquisa; objetivo da pesquisa; abordagem do problema; e procedimentos técnicos para executá-la. Estas áreas são ilustradas na Figura 7 - Métodos e Procedimentos metodológicos, que também apresenta em destaque os elementos metodológicos selecionados para a realização desta dissertação, conforme são descritos a seguir.

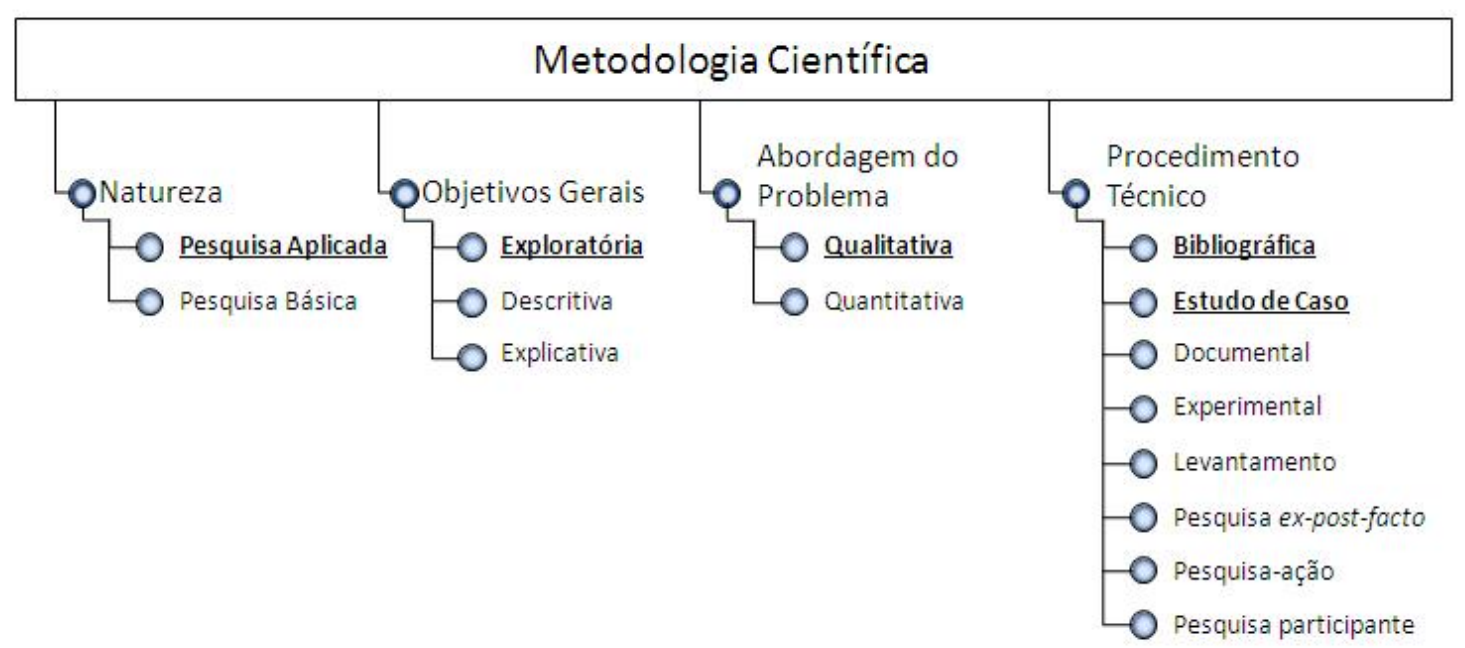

Figura 7 - Métodos e Procedimentos metodológicos

Fonte: Autora (2012)

Assim, o início está na definição da natureza do trabalho, podendo ser uma:

- Pesquisa Básica: busca originar conhecimentos novos úteis para o avanço da ciência sem prévia aplicação prática, por isso envolve verdades e interesses universais.

- Pesquisa Aplicada: objetiva gerar conhecimento para aplicação prática e dirigidos à solução de problemas específicos, em vista disso, abrange verdades e interesses locais.

Quanto a sua natureza, esta dissertação é classificada como pesquisa aplicada, pois visa contribuir com fins práticos, ao discutir a questão de como avaliar o quanto uma organização está preparada para desenvolver projetos sustentáveis de forma colaborativa. 
Tendo em vista os objetivos (GIL, 1991), pode-se optar pela:

- Pesquisa Exploratória: busca proporcionar maior familiaridade com 0 problema ao torná-lo explícito ou visando a construção de hipóteses. Envolve levantamento bibliográfico, entrevistas com pessoas que tiveram experiências práticas com o problema pesquisado e análise de exemplos que estimulem a compreensão. Em geral, direcionam seus esforços para a Pesquisa Bibliográfica e os Estudos de Caso.

- Pesquisa Descritiva: almeja descrever o estabelecimento de relações entre variáveis ou as características de determinada população ou fenômeno. Por isso, aplica técnicas padronizadas de coleta de dados: questionário e observação sistemática, para obter, normalmente um levantamento.

- Pesquisa Explicativa: pretende identificar fatores que determinam ou contribuem para a ocorrência de certos fenômenos; ela aprofunda o conhecimento da realidade porque explica a razão de tal fato existir, ou seja, o "porquê" das coisas. Quando realizada nas ciências naturais, requer o uso de prática experimental, e nas ciências sociais postula o uso do método observacional. Costuma assumir a forma de Pesquisa Experimental e Pesquisa Ex-post-facto.

Em vista disso, o objetivo deste trabalho se atém a pesquisa exploratória, uma vez que visa difundir uma problemática ainda pouco conhecida e torná-la compreensível. Afinal, ainda que existam estudos sobre o tema, a pesquisa exploratória pode ser útil, pois, para um mesmo fato, pode haver inúmeras explicações alternativas.

Outro modo de delinear a pesquisa é como abordar o problema, qualificando-o ou mensurando-o, a partir da:

- Pesquisa Quantitativa: por este método tudo pode ser quantificável, isso significa traduzir em números opiniões e informações para classificá-las e analisá-las. Requer recursos e técnicas estatísticas (porcentagem, média, mediana, moda, desvio-padrão, coeficiente de correlação, análise de regressão, etc.).

- Pesquisa Qualitativa: considera que há uma relação dinâmica entre o mundo real e o sujeito, isto é, um vínculo indissociável entre o mundo objetivo e a 
subjetividade dos atores, que não pode ser explicado em números. $\mathrm{O}$ processo e seu significado são os focos principais de abordagem. Por isso, a interpretação dos fenômenos e a atribuição de significados são essenciais nesta metodologia, que não se utiliza de técnicas estatísticas. Visto que o ambiente natural é a fonte direta para coleta de dados e o pesquisador é o instrumento-chave deste trabalho, o resultado e a análise dos dados é feita de maneira indutiva, pois as informações apuradas são descritivas.

Considerando a abordagem do problema, a presente pesquisa se caracteriza como qualitativa, pois busca entender um fenômeno específico em profundidade, trabalhando com descrições, comparações e interpretações dos dados obtidos.

E no que se refere a procedimentos técnicos (GIL, 1991), a investigação pode ser estruturada por:

a) Pesquisa Bibliográfica: a elaboração é feita a partir de textos já publicados as chamadas fontes de papel, constituído principalmente de livros, artigos, periódicos - e, recentemente, de materiais disponibilizados na internet.

b) Pesquisa Documental: desenvolvida a partir de materiais que não receberam tratamento analítico.

c) Pesquisa Experimental: depois de definido o objeto de estudo, selecionam-se as variáveis que seriam capazes de influenciá-lo e definem-se as formas de controle e observação dos efeitos que a variável pode produzir no objeto.

d) Levantamento: pesquisa que envolve a interrogação direta das pessoas cujo comportamento se deseja conhecer.

e) Estudo de caso: análise profunda e exaustiva de um ou poucos objetos, para que se obtenha um conhecimento amplo e detalhado deles. Segundo Yin (2003), é um estudo de caráter empírico que investiga um fenômeno atual no contexto da vida real, geralmente considerando as fronteiras entre 0 fenômeno e o contexto onde se está inserido (YIN, 2003).

f) Pesquisa Ex-post-facto: experimentos espontâneos, naturais, realizados depois dos fatos e examinados como se estes estivessem submetidos a um controle.

g) Pesquisa-ação: concebida e realizada em estreita associação com uma ação ou com a resolução de um problema coletivo. Os pesquisadores e 
participantes da investigação estão envolvidos de modo cooperativo ou participativo.

h) Pesquisa Participante: desenvolvida a partir da interação entre pesquisadores e membros das situações averiguadas.

Finalmente, levando-se em conta os procedimentos técnicos, este trabalho é determinado por:

- Pesquisa bibliográfica, pois parte de referências teóricas já publicadas, constituídas principalmente de livros e artigos de periódicos, para alicerçar e desenvolver o tema estudado, conhecendo e analisando as contribuições científicas do passado.

- Estudo de caso, porque envolve o estudo exploratório e qualitativo para coleta de dados e informações de grupos específicos. Este procedimento foi realizado pela questionário que objetivava investigar as características das organizações estudadas.

\subsection{UNIVERSO}

No sentido de alcançar o objetivo proposto, é efetuado o estudo de caso em dois projetos distintos que não são comparáveis entre si, mas que apresentam características semelhantes pesquisadas neste trabalho.

As características apresentadas por estes projetos foram: ambos foram realizados pela empresa de consultoria Axia Sustentabilidade, ao longo dos anos de 2011 e 2012; a sustentabilidade foi o fator motivador das iniciativas; em ambos os casos a execução das ações não seria possível de ser realizado por uma única empresa, havendo a necessidade da formação de aglomerados produtivos onde a colaboração permeou entre os participantes.

Em vista desses casos, será realizada a análise para avaliar o grau de maturidade das organizações que desejam trabalhar em forma de redes de cooperação nos projetos de promoção da sustentabilidade. 


\subsection{COLETA DE DADOS}

De acordo com Silva e Menezes (2005, p.33), existem quatro ferramentas para coleta de dados: observação, entrevista, questionário e formulário. O uso de cada uma delas dependerá do propósito que se pretende alcançar com a pesquisa e do universo a ser investigado.

Neste trabalho, em particular, foi desenvolvido um questionário com perguntas de múltipla escolha (ver Anexo I). Em que cada pergunta do questionário tem quatro alternativas como resposta. $\mathrm{Na}$ qual, a sequência das alternativas determina o grau de maturidade a ser avaliado, sendo que a primeira alternativa representa a opção de resposta com menor grau de maturidade e a última alternativa representa a opção com maior grau de maturidade.

A partir da definição das organizações a serem pesquisadas no estudo de caso e com o apoio do questionário de múltipla escolha, cada representante destas empresas foi convidado a responder um questionário. A partir das informações coletadas, foram feitas as análises da maturidade de cada organização, permitindo identificar o grau de maturidade de cada uma.

Em decorrência disso, como critério de escolha do representante de cada companhia, para responder o questionário, foi estabelecida a seguinte ordem: no caso em que a organização possui um Gerente de Sustentabilidade, este foi o selecionado, nos demais casos foi o representante da organização que responde pelos assuntos de sustentabilidade, como por exemplo, Gerente de Segurança e Meio Ambiente, Gerente de Comunicação, entre outros.

Com o objetivo de se obter respostas imparciais, sempre que possível, foi realizado o processo de coleta de dados com mais representantes de cada instituição. Com este procedimento, espera-se obter uma análise mais equilibrada de cada organização. 


\subsection{ANÁLISE DE DADOS}

Com as informações coletadas no questionário foi possível elaborar um painel evidenciando as características de colaboração e sustentabilidade de cada organização, podendo-se avaliar o grau de maturidade dessas organizações ao trabalhar em redes colaborativas nos projetos de promoção da sustentabilidade. 


\section{ESTUDO DE CASO}

Os estudos selecionados para este trabalho foram realizados pela empresa de consultoria Axia Sustentabilidade, ao longo dos anos de 2011 e 2012.

Estes casos são referentes a empresas e cidades sustentáveis, pois a maneira como elas se relacionam para alcançar o objetivo em comum - a diversidade de atores envolvidos (organizações do primeiro, segundo e terceiro setor) e a oportunidade de replicação destas redes entre organizações - desperta o interesse para analisar as características do tipo de rede formada e o grau de maturidade delas para atuar de forma colaborativa nestes grupos.

Assim, o projeto Cadeias Sustentáveis foi elaborado para desenvolver uma plataforma de colaboração que promovesse a formação de um grupo de organizações que pudesse se relacionar para construir e aplicar em conjunto soluções para os problemas relacionados à sustentabilidade. Após a concretização deste projeto, este grupo poderia se dissociar ou, até mesmo, ter a oportunidade de formar novos negócios.

Além de criar soluções sustentáveis, esta plataforma de colaboração tem como objetivo fomentar e disseminar o conhecimento entre seus participantes.

Enquanto isso, o projeto Rio Cidade Sustentável foi desenvolvido para estimular a aplicação de soluções de sustentabilidade em um determinado sistema, a partir da realização de um grupo de ações coordenadas operacionalizadas pelas organizações participantes que introduziram suas tecnologias, competências e soluções para atender os novos desafios propostos por este novo sistema ou modelo de gestão. Assim, as organizações que fazem parte dos estudos de caso estão em setores distintos, pois tratam-se de companhias do varejo, metalmecânica, construção civil, eletroeletrônica e serviços.

Nos itens seguintes são apresentadas descrições individualizadas de cada estudo de caso apurado. 


\subsection{PROJETO CADEIAS SUSTENTÁVEIS}

Organizações envolvidas: Indústria e Varejo.

Objetivo: Elaborar uma plataforma de colaboração e educação em sustentabilidade para desenvolver ações sustentáveis de forma colaborativa na cadeia. Localidade: São Paulo

\subsubsection{Informações gerais}

A demanda para a implantação de uma plataforma de colaboração e educação em sustentabilidade surgiu da necessidade de uma empresa de varejo expandir as ações sustentáveis dentro de sua própria cadeia de negócios.

Este caso analisado apresenta características que permitem caracterizá-lo com uma plataforma de colaboração e educação para a sustentabilidade, como por exemplo o nível de interação entre as organizações participantes que permitiu o desenvolvimento de conhecimento e o compartilhamento de informação. Além de esta Plataforma apresentar-se como uma ferramenta que possibilita a implementação de processos colaborativos de trabalho, ocasionando ações comuns de desenvolvimento sustentável dentro das organizações, e por consequência, gerando valor a todos os envolvidos.

Deste modo, conforme as informações são incorporadas e compartilhadas ao cotidiano das empresas, elas auxiliam na transformação da cadeia, pois ao trabalharem visando um bem maior e comum, desestimulam a competição, cultivam relacionamentos, compartilham conhecimento e viabilizam soluções sistêmicas.

\subsubsection{Plataforma de Colaboração e Educação em Sustentabilidade}

A Plataforma de Colaboração e Educação em Sustentabilidade é uma forma de organização entre empresas que se assemelha a uma Empresa Virtual. A plataforma 
descrita neste estudo de caso tem por objetivo trabalhar de forma colaborativa e temporária em um programa no qual os setores e organizações compartilham informações, recursos e responsabilidades para, em conjunto, planejar, implementar e avaliar um roteiro de atividades estabelecidas para atingir um determinado resultado. Sendo, neste caso, a empresa do setor de varejo a responsável pela gestão e organização desta plataforma de colaboração.

Segundo Ricci (2002), uma organização virtual ocorre em resposta às necessidades do consumidor e é uma agregação temporária de organizações autônomas e possivelmente heterogênea, concebida para promover flexibilidade e adaptabilidade às mudanças frequentes que caracterizam os cenários de negócio.

O sistema de operações desta Plataforma é representado pelas seguintes etapas:

1. Definir Temas/Cadeias e Fornecedores.

2. Convidar públicos envolvidos e elaborar propostas de ações.

3. Avaliar modelo operacional e business case.

4. Enviar planejamento para aprovação do orçamento disponível.

5. Preparar a gestão e execução das atividades.

6. Gestão e Execução das iniciativas.

\subsubsection{Projeto piloto}

Para validar as etapas de desenvolvimento e execução da Plataforma de Colaboração descritas neste trabalho, foi executado um projeto piloto ${ }^{4}$, denominado Cadeias Sustentáveis, entre Agosto de 2011 e Abril de 2012.

$\mathrm{Na}$ execução deste projeto foram envolvidas as áreas de sustentabilidade e logística das organizações participantes, para tanto se escolheu o setor de metal-mecânico ${ }^{5}$ como alvo do programa inicial.

Assim, em virtude da escolha do tema "Resíduos" como primeiro problema a ser trabalhado nessa plataforma, a empresa de varejo se aliou a indústria de

\footnotetext{
${ }^{4}$ Projeto piloto é um estudo experimental feito em pequena escala, com riscos e recursos reduzidos, visando testar previamente ideias e planos de ação.

${ }^{5}$ Setor de metal-mecânico: responsável pela produção de eletrodomésticos.
} 
eletrodomésticos e mais dois fornecedores do setor, para conseguir recuperar e dar destinação adequada aos produtos que estão no final do ciclo de vida ${ }^{6}$.

Definidos os atores envolvidos e a questão a ser resolvida, buscou-se suporte técnico: em conjunto com uma equipe de consultoria, um modelo de operações foi desenvolvido para recuperar e destinar de forma sustentável os eletrodomésticos da linha branca, fogões e lavadoras, em desuso.

E durante todo o processo de construção, implementação e execução, o projeto Cadeias Sustentáveis deu grandes passos para desenvolver elos de colaboração entre os stakeholders; e a cada etapa vencida, fortalecia o engajamento entre as indústrias participantes e a empresa varejista.

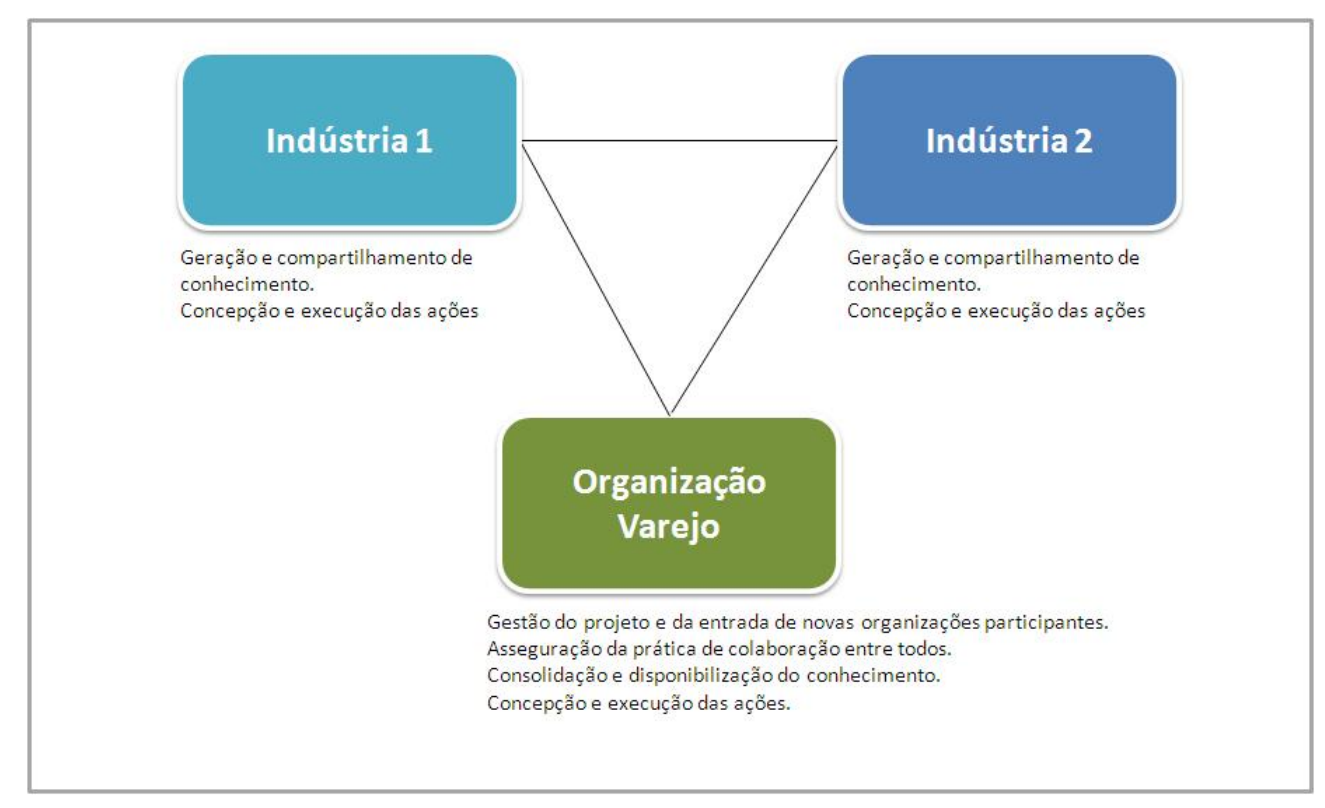

Figura 8 - Organização do projeto Cadeias Sustentáveis

Fonte: Autora (2012)

\subsection{PROJETO RIO CIDADE SUSTENTÁVEL}

Organizações envolvidas: primeiro e segundo setor.

\footnotetext{
${ }^{6}$ Produtos em fim de vida: produtos que serão descartados devido à obsolescência ou a falhas mecânicas.
} 
Objetivo: Reunir um grupo diversificado de organizações com o objetivo de colocar em prática iniciativas de desenvolvimento urbano que respeitem os critérios da sustentabilidade.

Localidade: Rio de Janeiro.

\subsubsection{Informações gerais}

Mais de $80 \%$ da população brasileira vive em cidades que apresentam todos os tipos de desafios para a sustentabilidade. A tendência é que as cidades brasileiras cresçam ainda mais nos próximos anos, sendo, portanto, urgente o desenvolvimento de soluções inovadoras e ações coordenadas que garantam o crescimento sustentável, sobretudo nas áreas urbanas.

No cenário internacional a preocupação continua e temas ligados a sustentabilidade tem cada vez mais relevância. Logo, promover novas formas de intervenções menos invasivas no planeta parece urgente, e disto surgiu a Iniciativa de Infraestrutura Urbana, um programa de planejamento de cidades sustentáveis, concebido pelo World Business Council for Sustainable Development ${ }^{7}$ (WBCSD).

Esta Iniciativa de Infraestrutura Urbana foi concretizada pelo Conselho Empresarial Brasileiro para Desenvolvimento Sustentável (CEBDS) ${ }^{8}$, representante do WBCDS no Brasil, com o desejo de fomentar conhecimentos e iniciativas tecnológicas intrasetoriais, além de viabilizar ações integradas com foco na sustentabilidade.

Como resultado deste desejo de mudanças, por iniciativa do CEBDS, a prefeitura do Rio de Janeiro se associou ao governo estadual na implantação do projeto Rio Cidade Sustentável. Ainda ativo, ele possui escopo e funcionamento próprios para o planejamento urbano sustentável, e seu intuito é desenvolver soluções sistêmicas inovadoras e duradouras servindo de referência para o desenvolvimento sustentável em outras cidades.

\footnotetext{
${ }^{7}$ WBCSD: organização liderada por CEOs e Conselhos de Administração de empresas que atuam junto com a comunidade global de negócios para criar uma economia ecologicamente sustentável e consequentemente um futuro sustentável para a sociedade empresarial e o meio ambiente.

${ }^{8}$ O CEBDS reúne 56 empresas com produtos, serviços e conhecimento técnico para enfrentar os desafios da sustentabilidade.
} 


\subsubsection{Projeto Rio Cidade Sustentável}

É crescente o envolvimento das organizações com alianças e parcerias que as levam a agir além das tradicionais fronteiras organizacionais (Austin, 2002). Os desafios que as organizações enfrentam requerem cada vez mais o esforço colaborativo e a efetiva ação coordenada de várias organizações, incluindo governo, setor privado e terceiro setor. Colaborar tornou-se um imperativo.

O Projeto Rio Cidade Sustentável é uma forma de relacionamento entre organizações que se assemelha ao conceito de redes de empresas, apesar de ter atuado em duas comunidades locais do Rio de Janeiro: Chapéu Mangueira e Babilônia, envolveu ao longo do projeto diversos stakeholders como moradores da região, governo, setor privado e terceiro setor.

Com tantos atores envolvidos, a gestão e organização deste projeto foram divididas entre o CEBDS, a ONG, as instituições patrocinadoras e a consultoria.

Em vista disso, o objetivo foi trabalhar de forma colaborativa na realização de um grupo de ações coordenadas pelas empresas participantes, introduzindo suas tecnologias, competências e soluções para promover sustentabilidade local.

Este trabalho, desde a escolha do projeto até a apresentação do case, dependeu de um plano de ação, que foi dividido da seguinte forma:

1. Convidar organizações para participarem do projeto.

2. Criar uma visão compartilhada para o projeto.

3. Realizar diagnóstico atual no local que sofrerá as intervenções.

4. Avaliar a viabilidade técnica e a geração de plano de ações.

5. Preparar a gestão e implantação de frentes de atuação.

6. Administrar e Executar as iniciativas.

7. Elaborar e apresentar case.

O relacionamento entre as organizações do Projeto Rio Cidade Sustentável respeita a estrutura de governança como pode ser visualizado na Figura 10. 


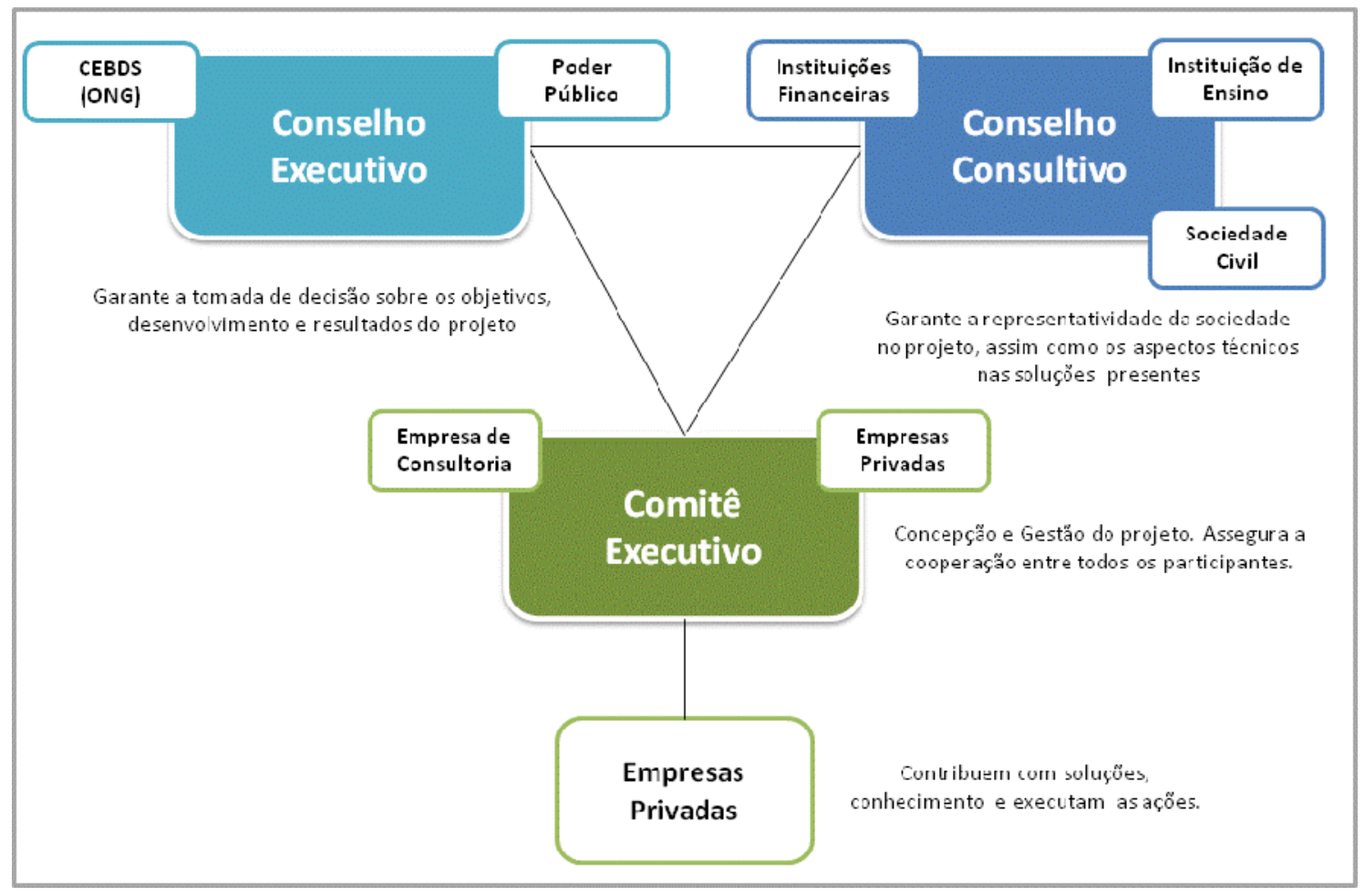

Figura 9 - Organização do projeto Rio Cidade Sustentável Fonte: Consultoria Axia Sustentabilidade (2011)

\subsubsection{Projeto piloto: Infraestrutura Urbana}

A elaboração do plano de ação do Projeto Rio Cidade Sustentável definiu frentes de trabalho e teve como resultado a iniciativa Melhoria Habitacional Sustentável. Esta frente de trabalho buscou melhorar a estrutura das habitações garantindo maior conforto, segurança e condições sanitárias.

Para a realização desta iniciativa de trabalho foi necessário que organizações distintas como instituições financeiras, empresas privadas e poder público trabalhassem de forma colaborativa para execução das atividades.

Este apoio técnico-financeiro permitiu a capacitação de moradores locais em tecnologias de construção sustentável, o acesso a crédito para compra de materiais de construção, a organização de trabalho cooperativo entre moradores para execução das obras (mutirão), o mapeamento dos principais problemas deste tipo de habitação e o monitoramento dos resultados alcançados. 


\section{RESULTADOS}

\subsection{RESULTADOS E CONTRIBUIÇÕES}

\subsubsection{Resultados da Pesquisa}

O presente trabalho buscou avaliar o conhecimento em sustentabilidade e a colaboração entre as organizações para o desenvolvimento de projetos. Para isso analisou o grau de maturidade em sustentabilidade e o engajamento colaborativo das organizações participantes dos projetos Cadeias Sustentáveis e Rio Cidade Sustentável. O questionário utilizado para esta pesquisa está disponível no final da dissertação (ver Anexo I).

Como pode ser visto desde o capítulo anterior, os nomes dos atores envolvidos, sejam instituições ou indivíduos, não foram divulgados, a fim de preservar suas identidades. As características das organizações participantes estão descritas a seguir, de acordo com as respostas obtidas no questionário aplicado e agrupadas em quatro seções:

$>$ A primeira seção apresenta um resumo da empresa: o setor de atuação e seu porte no mercado.

$>$ A segunda seção, questões 01 a 11 do questionário, avalia o grau de maturidade em sustentabilidade. Cada questão possui quatro alternativas de resposta, que estão ordenadas pelo nível de maturidade em sustentabilidade. Primeira resposta com menor nível e a quarta resposta com nível maior de maturidade em sustentabilidade.

$>$ A terceira seção, questões 12 a 14 do questionário, determina o nível de engajamento para colaboração, que estão ordenadas pelo nível de colaboração. Primeira resposta com menor nível e a quarta resposta com nível maior de colaboração.

$>\mathrm{Na}$ quarta seção é descrita as oportunidades, desafios e lições aprendidas ao atuar de forma sustentável. 
Todas estas informações contribuem para avaliar em que medida estas empresas estavam preparadas para trabalhar de forma colaborativa e os impactos dessa maturidade nos resultados do projeto realizado.

\subsubsection{Cadeias Sustentáveis}

Este caso é composto por três organizações de dois setores distintos, e possuem as seguintes características sociais: a empresa varejista é de grande porte, de origem brasileira, com matriz localizada em São Paulo e controle acionário exercido por um grupo francês; a organização A do setor de metal-mecânico é de grande porte, vem de uma fusão americana e brasileira, e têm filiais no Brasil e nos Estados Unidos; a organização B do setor metal-mecânico é de grande porte, de origem mexicana com filiais no Brasil, México, Venezuela e Equador.

Dessa forma, a organização do setor de varejo apresenta uma definição corporativa de sustentabilidade apenas no nível executivo e as estratégias de sustentabilidade são pensadas em áreas restritas. Mesmo assim, ela tem conhecimento de suas externalidades $^{9}$ e stakeholders, com canais de comunicação bidirecionais; contrapondo com a bonificação dos executivos, que é baseada somente nos resultados econômicos de curto prazo. E apesar de ter uma área específica para desenvolvimento de projetos sustentáveis, ela apresenta dificuldades para disseminar essas práticas para outros setores da corporação.

Isso reforçou as últimas conclusões obtidas: o baixo nível de colaboração, e embora, a organização fosse a responsável pela gestão, se envolvendo na concepção das ações e desenvolvendo relacionamento com stakeholders, ficou nítido que ela planejou as ações individualmente e verticalmente.

A segunda companhia a ser avaliada é a organização A, do setor metal-mecânico. Com uma definição corporativa do termo apenas no nível executivo, a sustentabilidade está presente em algumas ações estratégicas, mas não existe uma estratégia corporativa global. Também não há critérios definidos para seleção dos

9 Externalidade: atividade que envolve a imposição involuntária de custos ou de benefícios de um agente sobre outro, isto é, ação que produz efeitos positivos ou negativos sobre terceiros sem que possam impedi-los ou indeniza-lo por tal ato. 
stakeholders, o processo de comunicação é simples, a bonificação dos executivos é baseada somente nos resultados econômicos de curto prazo e o nível de colaboração percebido é baixo. Ainda assim, a organização notou objetivos complementares e alinhamento de atividades, e se envolveu no desenvolvimento e concepção das atividades propostas.

Para terminar, a organização B do setor metal-mecânico apresenta uma definição corporativa de sustentabilidade, porém sua utilização não é uniforme em todos os níveis da corporação e não reflete a estratégia da organização - como na comunicação, que é unilateral, e na bonificação dos executivos, baseada somente nos resultados econômicos de curto prazo.

Ela também não apresenta uma estrutura dedicada ao desenvolvimento de projetos sustentáveis, correspondendo ao baixo nível de colaboração; basta ver que, apesar de se envolver na concepção das ações, encontrou dificuldades financeiras e falta de equipe dentro de sua organização para a integração e desenvolvimento do projeto.

A seguir, o Quadro 3, traz uma síntese das respostas obtidas no questionário.

As repostas completas deste questionário estão disponíveis no final da dissertação (ver Anexo II).

\begin{tabular}{|c|c|c|c|}
\hline Questões & Varejo & Metal-Mecânico A & Metal-Mecânico B \\
\hline $\begin{array}{l}\text { Caracteristica da } \\
\text { Organização }\end{array}$ & $\begin{array}{l}\text { - Grande porte } \\
\text { - Origem brasileira } \\
\text { - Controle acionário francês }\end{array}$ & $\begin{array}{l}\text { - Grande porte } \\
\text { - Fusão americana e brasileira }\end{array}$ & $\begin{array}{l}\text { - Grande porte } \\
\text { - Origem mexicana }\end{array}$ \\
\hline $\begin{array}{l}\text { Grau de Maturidade } \\
\text { em Sustentabilidade }\end{array}$ & $\begin{array}{l}\text { - Sustentabilidade não está } \\
\text { disseminada na organização } \\
\text { - Externalidades e stakeholders } \\
\text { - Com unicação bidirecional } \\
\text { - Bônus dos executivos leva em conta } \\
\text { resul tado socioambiental }\end{array}$ & $\begin{array}{l}\text { - Sustentabilidade presente em } \\
\text { algum as açỗes estratégicas } \\
\text { - Não há interação com } \\
\text { stakeholders } \\
\text { - Comunicação unilateral } \\
\text { - Bônus dos execu tivos leva em } \\
\text { conta resultado so cio ambiental }\end{array}$ & $\begin{array}{l}\text { - A definição de } \\
\text { sustentabilidade não é } \\
\text { homogênea na empresa } \\
\text { - Comunicação reativa } \\
\text { - Bônus dos executivos é } \\
\text { baseada em resul tado } \\
\text { econômico de curto prazo }\end{array}$ \\
\hline $\begin{array}{l}\text { Nivel de engajamento } \\
\text { para colaboração }\end{array}$ & $\begin{array}{l}\text { - Objetivos compatíveis } \\
\text { - Trabalho separado } \\
\text { - Concep ção das ativida des }\end{array}$ & $\begin{array}{l}\text { - Objetivos com plementares } \\
\text { - Alinhamento de atividades } \\
\text { - Concepção das a tividades }\end{array}$ & $\begin{array}{l}\text { - Objetivos complementares } \\
\text { - Alinhamento de atividades } \\
\text { - Concepção das atividades }\end{array}$ \\
\hline $\begin{array}{l}\text { Oportunidades, } \\
\text { desafios e lições } \\
\text { aprendidas }\end{array}$ & $\begin{array}{l}\text { - Falta de participação dos membros } \\
\text { da rede } \\
\text { - Melhor ar a comunicação } \\
\text { - Interação com novos clientes } \\
\text { - Novos Negócios }\end{array}$ & $\begin{array}{l}\text { - Falta de participação dos } \\
\text { membros da rede } \\
\text { - Melhorar a comunicação } \\
\text { - Desenvolvimento de novos } \\
\text { produtos } \\
\text { - Visibilidade da marca }\end{array}$ & $\begin{array}{l}\text { - Falta de recurso adequado } \\
\text { - Alinhamento com a estratégia } \\
\text { do negócio } \\
\text { - Visibilidade da marca } \\
\text { - Novos Negócios }\end{array}$ \\
\hline
\end{tabular}

Quadro 3 - Síntese do resultado do questionário - Cadeias Sustentáveis Fonte: Autora (2013) 


\subsubsection{Rio Cidade Sustentável}

Este caso é composto por organizações de três setores distintos, que possuem as seguintes características: a organização do setor de construção civil é de grande porte tem origem brasileira e a matriz está fixada em São Paulo; a organização do setor eletroeletrônico também é de grande porte com origem alemã e filiais instaladas em São Paulo e Amsterdã; e a organização do setor de serviços é de médio porte, de origem brasileira e com matriz localizada em São Paulo.

Em relação ao conceito de sustentabilidade difundido nas organizações, o resultado dos testes mostrou que a empresa de construção civil apresenta uma clara compreensão do que é sustentabilidade e como este assunto está relacionado a seu setor de atuação, estando, inclusive, incorporada aos próprios planos de gestão. No que diz respeito ao conhecimento de suas externalidades e políticas de transparência e comunicação, a organização tem conhecimento razoável e apresenta práticas desenvolvidas; porém tem dificuldade para desdobrar a estratégia definida para sustentabilidade nos níveis operacionais. Por isso, o nível de colaboração percebido é baixo, e embora os objetivos e a identidade visual fossem compatíveis com o projeto, a execução das ações foi realizada de forma individual.

A segunda organização analisada, a do setor de eletroeletrônicos, apresenta o conceito de sustentabilidade difundido internamente e uma clara compreensão de como isto está associado ao seu setor de atuação, tanto que, atualmente, já trabalha em conjunto com os públicos de interesse analisando questões de sustentabilidade. Com isso, pôde identificar suas externalidades, no entanto, a sua política de transparência e os canais de comunicação ainda são limitados, assim como os quesitos de sustentabilidade não são considerados na remuneração dos executivos. Apesar de consciente de seu papel, ainda apresenta dificuldades para desdobrar a estratégia definida para sustentabilidade nos níveis operacionais, mesmo assim, o nível de colaboração percebido é mediano, pois a organização se envolveu na concepção das ações e desenvolveu relacionamento com stakeholders, embora tenha realizado as ações individualmente.

E por último, a organização do setor de serviços, que tem o conceito de sustentabilidade difundido no nível executivo e passa a disseminá-lo pelos demais níveis da organização. Por este fato, a sustentabilidade já se reflete em algumas 
ações estratégicas, mas não existe um programa interno para a questão. Tanto que a organização apresenta uma baixa compreensão sobre suas externalidades, não há política definida de transparência e a bonificação dos executivos é baseada somente nos resultados econômicos de curto prazo. A consequência dessas ações se traduz na falta de integração entre as estratégias de sustentabilidade da organização e os processos e operações internos. Que também é confirmado no baixo nível de colaboração percebido, pois embora a organização tenha se envolvido na elaboração e desenvolvimento das ações, houve pouca comunicação e troca de informações, gerando conflitos em alguns momentos.

Esse foi o resumo dos dados apurados no questionário respondido pelas organizações envolvidas no projeto Rio Cidade Sustentáveis. O Quadro 4, traz uma síntese das respostas obtidas no questionário.

As repostas completas deste questionário estão disponíveis no final da dissertação (ver Anexo III).

\begin{tabular}{|c|c|c|c|}
\hline Questĉes & Construção Civil & Eletroeletrônicos & Serviços \\
\hline $\begin{array}{l}\text { Característica da } \\
\text { Organização }\end{array}$ & $\begin{array}{l}\text { - Grande porte } \\
\text { - Origem brasileira }\end{array}$ & $\begin{array}{l}\text { - Grande porte } \\
\text { - Origem alemă }\end{array}$ & $\begin{array}{l}\text { - Médio porte } \\
\text { - Origem brasileira }\end{array}$ \\
\hline $\begin{array}{l}\text { Grau de Maturidade } \\
\text { em Sustentabilidade }\end{array}$ & $\begin{array}{l}\text { - Sustentabilidade está alinhada em } \\
\text { todos os níveis da organização } \\
\text { - Programas extensivos de } \\
\text { comunicação } \\
\text { - Externalidades e stakeholders } \\
\text { - Comunicação bidirecional } \\
\text { - Bônus dos executivos leva em conta } \\
\text { resultado socioambiental }\end{array}$ & $\begin{array}{l}\text { - Sustentabilidade difuncido } \\
\text { internamente } \\
\text { - Trabalho em conjunto com os } \\
\text { públicos de interesse } \\
\text { - Bônus dos executivos é baseada } \\
\text { em resultado econômico de curto } \\
\text { prazo }\end{array}$ & $\begin{array}{l}\text { - A definição de } \\
\text { sustentabilidade não é } \\
\text { homogênea na empresa } \\
\text { - Comunicação reativa } \\
\text { - Bônus dos executivos é } \\
\text { baseada em resultado } \\
\text { econômico de curto prazo }\end{array}$ \\
\hline $\begin{array}{l}\text { Nivel de engajamento } \\
\text { para colaboração }\end{array}$ & $\begin{array}{l}\text { - Objelivus cumpalíveis } \\
\text { - Concepção das atividades } \\
\text { - Atuação individual }\end{array}$ & $\begin{array}{l}\text { - Obje tivus cumpa tiveis } \\
\text { - Concepção das atividades } \\
\text { - relacionamento stakeholders }\end{array}$ & $\begin{array}{l}\text { - Truca de infurmação } \\
\text { - Concepção das atividades } \\
\text { - Comercializou seus produtos }\end{array}$ \\
\hline $\begin{array}{l}\text { Oportunidades, } \\
\text { desafios eliç̃es } \\
\text { aprendidas }\end{array}$ & $\begin{array}{l}\text { - Falta de participação dos membros } \\
\text { da rede } \\
\text { - Desconfiança dos executivos } \\
\text { - Melhorar a comunicação } \\
\text { - Interação com novos clientes } \\
\text { - Novos Negócios / Produtos }\end{array}$ & $\begin{array}{l}\text { - Falta de participação dos } \\
\text { membros da rede } \\
\text { - Alinhamento com a estratégia do } \\
\text { negócio } \\
\text { - Desenvolvimento de novos } \\
\text { produtos } \\
\text { - Visibilidade da marca }\end{array}$ & $\begin{array}{l}\text { - Fal ta de integração entre os } \\
\text { nós da rede } \\
\text { - Alinhamento com a estratégia } \\
\text { do negócio } \\
\text { - Necessidade de adaptação dos } \\
\text { produtos } \\
\text { - Novos Negócios }\end{array}$ \\
\hline
\end{tabular}

Quadro 4 - Resultado do questionário - Rio Cidade Sustentável Fonte: Autora (2013) 


\subsubsection{Síntese}

O que foi percebido nas seis organizações do estudo de caso é que não havia maturidade delas ao atuar de forma colaborativa, pois o conceito de sustentabilidade não foi incorporado nas estratégias das empresas e disseminado na rede, e sim, imposto pelos executivos, os "tomadores de decisão" (ainda que no projeto Rio Cidade Sustentável, as empresas tivessem um conhecimento maior sobre o tema e já o informava nos planos de negócios). A colaboração foi uma relação intencional, restrita, demonstrando que as organizações não estavam preparadas para atuar de forma conjunta.

Assim, a análise específica destes dois casos sugere aprendizados interessantes que podem ser usados como benchmarking ${ }^{10}$ para a implantação de outros projetos de sustentabilidade realizados de forma colaborativa. Desta maneira, os resultados e problemas aqui descritos podem guiar a política de desenvolvimento de outras redes, ao propor diretrizes de um modelo de gestão e interação que possa impulsionar as atividades do projeto.

Aos grupos de organizações que pretendem trabalhar de forma colaborativa em projetos de sustentabilidade, os principais aspectos identificados a serem melhorados foram:

- Disseminar o conhecimento em sustentabilidade: apesar do conceito de sustentabilidade ser atual e estar em pauta na agenda dos executivos, é importante que todos aqueles que participem da rede tenham a mesma compreensão sobre o termo e qual a importância deste nas atividades em que estão inseridos. A essência do grupo está na aprendizagem e disseminação do conhecimento, onde estas atividades são processos contínuos de construção social e coletiva, e devem ser incorporadas no grupo. A interação e o compartilhamento do conhecimento desenvolve uma cultura comum, desde a linguagem até a adoção de práticas coerentes com o trabalho e principalmente uma cultura de cooperação possibilita o desenvolvimento de novas ideias e processos, decorrentes da conversação e troca de informações, fortalecem as bases individuais e coletivas de certa

\footnotetext{
${ }^{10}$ Benchmarking: processo que busca avaliar a posição atual de uma organização em relação às "melhores práticas" e identificar as áreas e os meios para melhoria do desempenho.
} 
habilidade. Neste trabalho, fica claro que cada organização dissemina e incorpora o assunto de forma distinta. Cabe ao papel do agente indutor da rede promover a disseminação do conhecimento, pois a interação entre os atores fortalece o conhecimento individual e coletivo do grupo.

- Garantir a comunicação: elemento chave no planejamento e execução de todo o projeto. Uma boa comunicação promove a interação e se torna estratégica para a gestão da rede. Com o desenvolvimento sustentável e as redes de empresas trabalhando de forma colaborativa, princípios como ética, respeito, solidariedade e transparência voltam a ser valorizados, e são estes os requisitos para o estabelecimento de relações duradouras com os interlocutores. Ou seja, é incorporar uma comunicação mais transparente, mais horizontal, mais humanizada aos problemas de forma a conciliar a questão social e ambiental ao âmbito da ética da sociedade. Mas isto não é prática empresarial cotidiana, já tão acostumada ao imediatismo, a busca desenfreada do lucro, a obsolescência programada e a lógica do descartável, como visto na análise dos casos. Santa Cruz (2009) ressalta o papel dos meios de comunicação como mediador da sociedade e do espaço público e a importância dele na construção da sustentabilidade. Assim, um modelo sustentável deve utilizar a comunicação como gerenciadora do intenso fluxo de informação e, ao mesmo tempo, incorporá-la como elemento de informação, formação cultural e educação - interna e externamente -, disseminando, compartilhando e propiciando entendimentos entre as áreas para que resultem na adoção e aceitação de práticas sustentáveis de forma consciente, incorporando-as como parte de seus valores (MACEDO, 2011). Com isso, ela pode ser definida como estratégia, processo e mecanismo para estabelecer diálogo entre diferentes atores sociais que encontram, a partir dela, afinidades e laços.

- Estabelecer relação de confiança: a confiança mútua é a base da colaboração para que as organizações tenham condições de cooperar com os deveres que devem ser cumpridos. É o fator determinante para garantir a adesão das organizações, sendo necessário estabelecer o entendimento e a conciliação entre as respectivas culturas e valores e o objetivo comum a ser alcançado. O aumento da confiança impacta a similaridade de valores entre as partes e, 
consequentemente, aumenta o seu envolvimento, promove a reciprocidade e contribui para o compromisso relacional, concretizando a relação de confiança entre as partes. Desta forma, a interação entre as partes ocorre de forma natural, há melhora na comunicação, contribuição e disseminação do conhecimento dentro da rede.

\subsubsection{Perspectivas}

Embora já discutido ao longo do texto, é interessante apresentar as discussões sobre o potencial de se trabalhar com redes de colaboração em organizações para a busca de eficiência coletiva.

A necessidade de se adaptar às mudanças do mercado, impostas pelo conceito da sustentabilidade não apenas em produtos, mas também em serviços, entre outros fatores, está levando as empresas a inovarem incessantemente para garantir a satisfação do cliente. E inovação constante significa adquirir novas competências continuamente.

A configuração de redes de colaboração permite uma flexibilidade às organizações participantes tanto pelo acesso mais rápido a conhecimento e novas tecnologias, como pela possibilidade de arranjar novos parceiros na tentativa de oferecer uma solução ágil e inovadora a seus clientes; visto que a difusão do conhecimento tem se mostrado bastante eficiente em função do surgimento das atuais tecnologias de comunicação e informação.

Em função disto, é necessário agora estabelecer o processo de gestão adequado para a disseminação do conhecimento entre as redes colaborativas, promovendo o desenvolvimento sustentável para as organizações, sociedade e meio ambiente. 


\section{CONCLUSÃo}

\subsection{CONCLUSÃO}

Resgatando o objetivo geral desta pesquisa "avaliar o grau de maturidade em sustentabilidade e o engajamento colaborativo nas organizações que desejam trabalhar em forma de redes de empresas nos projetos de promoção da sustentabilidade", busca-se neste capítulo apresentar as principais considerações sobre este trabalho.

Novamente, relata-se sobre a seleção dos estudos de caso realizado nesta pesquisa. Apesar de serem dois modelos de casos distintos entre si, apresentam características similares como a diversidade de atores envolvidos (organizações do primeiro, segundo e terceiro setor), a forma de relacionamento para alcançar o objetivo comum. Além dos propósitos semelhantes, como o desenvolvimento de ações mais benéficas à sociedade, ao meio ambiente e à economia para gerar uma solução completa do problema.

Este, aliás, é um destaque desta da pesquisa, pois mesmo os estudos de caso sendo realizado em modelos distintos, tornou-se possível avaliar o grau de maturidade em sustentabilidade e o engajamento das organizações participantes. Com base em todas as informações levantadas, foi possível realizar a análise proposta e apresentar os resultados alcançados, contribuindo significativamente ao explorar os aspectos de cada rede analisada: suas deficiências, perspectivas e formas de aprimorá-la.

O estágio da maturidade está no que cada organização consegue perceber e agir em prol de uma sociedade mais sustentável, em um ambiente onde as condições para a continuidade da vida sejam preservadas. A sustentabilidade pode ser compreendida como o processo de evolução da maturidade e consciência das organizações na preservação do meio ambiente e na manutenção das condições fundamentais para a vida das gerações futuras.

O engajamento para colaboração está na maneira como as empresas se relacionam para enfrentar os desafios. A medida que as empresas e os indivíduos se relacionam, eles passam de redes cooperativas para colaborativas, ou seja da transferência de conhecimento e tecnologias elas migram para o compartilhamento 
destes, pois a relação de confiança aumenta. Mas esta confiança só aumenta e se mantém a longo prazo quando há um mesmo entendimento entre as partes: conhecendo os envolvidos (stakeholders), estratégias e ações; partilhando projetos comuns; anulando a concorrência entre os membros; respeitando o tempo e o espaço de cada integrante, afinal em cada parte da rede existem pessoas e elas processam mais do que dados e números em suas ações. O relacionamento estabelecido entre os grupos estudados puderam ser caracterizadas em tipos de redes.

Os casos, Cadeias Sustentáveis e Rio Cidade Sustentável, apresentaram peculiaridades que podem ser destacadas e servir de referência para outros casos. Por um lado, as organizações participantes do projeto Cadeias Sustentáveis tem influências culturais de outros países, devido à origem da matriz ou do grupo acionário; estas organizações descreveram níveis semelhantes de maturidade em sustentabilidade, ou seja, a capacidade de percepção das necessidades do sistema para o desenvolvimento e execução de ações é semelhante. Houve dificuldade em se relacionar de forma colaborativa, o que verificou a necessidade de melhorar a comunicação e a interação com os atores envolvidos para que obtenham sucesso em sua atual estratégia de organização virtual. Neste aspecto, também é preciso trabalhar o desenvolvimento das relações de confiança para que os níveis de interação sejam ampliados.

Enquanto isso, as organizações participantes do caso Rio Cidade Sustentável relataram baixos níveis de maturidade em sustentabilidade; visto que o conceito ainda está parcialmente incorporado nas respectivas organizações e apresentaram dificuldades para perceber e agir der forma conjunta nas ações de sustentabilidade; mas também informaram sobre a oportunidade de aumentar a interação com os atores envolvidos, o que permitiria uma possibilidade de ampliar o conhecimento destes em sustentabilidade e colaboração e fortalecer a rede colaborativa estabelecida.

Foi percebido que os setores operacionais não partilhavam do mesmo propósito porque não houve preocupação em prepará-los para este novo modelo e a diferença, a partir daquele momento, é que não havia só hierarquia dentro da empresa, mas entre elas (basta ver o projeto Cadeias Sustentáveis, no qual, a empresa varejista que encabeçou o projeto foi a mesma que direcionou o trabalho). 
Portanto, a falha no processo de implantação de um projeto sustentável passa pela gestão tradicional de negócios que não vê a comunicação como elemento de informação, formação cultural e educação, mas sim, como ferramenta de divulgação da empresa na mídia. O baixo conhecimento do empresariado brasileiro reflete a facilidade dessas redes se desfazerem e porque os processos sustentáveis são projetados a curto prazo.

Logo, fica evidente que assim como a comunicação, o tempo é uma variável contraditória nos projetos sustentáveis, pois se busca soluções imediatas e inovadoras, e concomitantemente se busca permanecer no mercado construindo relações a longo prazo.

Portanto, apesar de serem apenas dois casos analisados, nota-se que alguns dos entraves do desenvolvimento sustentável e da criação de redes de empresas são o tempo, o conhecimento, a comunicação e as relações de confiança. Porém de que adianta questionar se outros modelos de gestão sustentáveis são viáveis, se a sustentabilidade não é compreendida a fundo e a comunicação não é considerada elemento estratégico dentro de um grupo - há poucas pesquisas experimentais tratando da relação comunicação, sustentabilidade e mercado corporativo, como já foi expresso anteriormente.

Nos exemplos deste estudo, o diálogo não fluiu como se desejava e não houve compartilhamento de ideias e técnicas porque os gestores não estavam preparados para trabalhar de forma horizontal, a não ser entre seus pares, e os que estavam em baixo na cadeia não entenderam porque tinham de trabalhar com a "concorrência". Ou seja, o conceito de sustentabilidade está longe de todas as esferas da organização.

Em vista disto, a empresa de consultoria e o setor de comunicação destas empresas, que estão interligadas em rede, deveriam levar em conta, na fase inicial do projeto, os aspectos discutidos acima, para assim promover a sensibilização dos stakeholders, a facilitação do processo e o estabelecimento das relações de confiança de forma mais abrangente.

O que se comprovou é que se não há diálogo não há relação de confiança, nem maturidade e muito menos engajamento, não havendo promoção da sustentabilidade e nem equilíbrio dentro das redes. Portanto é eminente que se compartilhe casos de ações sustentáveis, para que além de servirem de base a 
outros estudos, eles sejam exemplos práticos de que a sustentabilidade e as redes colaborativas podem trazer excelente resultados.

\subsection{LIMITAÇÕES}

\subsubsection{Limitação de método}

Quanto ao estudo de caso, o método de pesquisa empregado, por um lado, auxilia o pesquisador a familiarizar-se com o problema e enxergar o relacionamento entre as variáveis de pesquisa em uma situação real. Por outro lado, ele apresenta um caráter qualitativo, no qual não se podem generalizar as informações obtidas como verdades absolutas para outros casos. Ademais, o estudo de apenas dois casos é uma limitação quanto ao método de pesquisa e pode influenciar o modelo proposto de forma errônea.

Mas esta pesquisa deve ser pensada como parte integrante de uma pesquisa maior, na qual outras redes de colaboração podem ser pesquisadas; e conforme novas pesquisas são concluídas, possíveis erros tenderão a diminuir, enquanto o modelo sustentável evolui.

\subsubsection{Limitação do modelo proposto}

Devido ao caráter da pesquisa, feito para avaliar o grau de maturidade em sustentabilidade e o engajamento para colaboração entre organizações distintas, foi constatado as diferenças de como estes conhecimentos estão disseminados dentro de cada organização.

Como aprendizado desta investigação fica a necessidade de interagir melhor com os tomadores de decisão de cada organização para compreender a fundo o que esperam e como imaginam seu papel no projeto. 
Fica também a lição de que o contato com organizações e equipes para sensibilização, facilitação do processo e estabelecimento das relações de confiança nas fases iniciais dos projetos mostrou-se importante. Além do mais, essa convivência poderia contribuir para que as organizações construíssem uma visão compartilhada em cada projeto, superando dificuldades encontradas ao longo do tempo.

E tempo pareceu uma variável limitante, tanto para implantação do processo como para a avaliação dos resultados alcançados, afinal os casos analisados deveriam ser acompanhados por um tempo maior, basta observar que as pessoas precisam de tempo para absorver a sustentabilidade nas estratégias da empresa. Neste processo, também é preciso compreender que o tempo de permanência das organizações que compõem as ações de cada projeto é distinto e que isto acaba comprometendo a produção de conhecimento e o prazo para execução do objetivo proposto.

Outro fator limitador para esta pesquisa são os demais modelos de projetos para colaboração em sustentabilidade que não foram explorados ao longo deste trabalho. Isso abre espaço para identificar a existência de outros casos e realizar análises comparativas entre as diferentes formas de desenvolvimento sustentável.

\subsection{PROPOSTAS DE PESQUISA FUTURA}

Com base nas informações encontradas durante o estudo, outras questões se abrem e outras pesquisas podem ser idealizadas, dentre as quais podem se destacar:

- Continuidade da pesquisa para avaliar se as organizações se sentem motivadas a participar novamente de outros projetos de forma colaborativa.

- Realizar pesquisa para avaliar se as organizações participantes identificaram a necessidade de ampliar seu nível de conhecimento em sustentabilidade.

- Estabelecer indicadores de avaliação para estes tipos de projetos, considerando métricas claras, mesmo que intangíveis. Com isto, se permitirá 
futuras avaliações comparativas, principalmente na replicação deles em outros contextos semelhantes.

- Verificar a existência, analisar e avaliar outros modelos de projetos colaborativos sustentáveis. 


\section{REFERÊNCIAS}

AMATO NETO, J. Gestão de sistemas locais de produção e inovação

(clusters/APLs) Um modelo de referência. São Paulo: Atlas, 2009, 184 p.

Redes dinâmicas de cooperação e organizações virtuais.

In: AMATO NETO, J. (org.). Rede entre organizações: domínio do conhecimento e da eficácia operacional. São Paulo: Atlas, 2005, p. 17-38.

Redes de cooperação produtiva e clusters regionais:

oportunidades para as pequenas e médias empresas. São Paulo: Atlas, 2000, $163 \mathrm{p}$.

Os desafios da produção e do consumo sob novos

padrões sociais e ambientais. In: AMATO NETO, J. (org.). Sustentabilidade e produção. São Paulo: Atlas, 2011, p.1-12.

BREMER, C. F. Encontro de competências. In: Revista Fapesp on line, São Paulo, v.48, 1999. Disponível em:

<http://revistapesquisa.fapesp.br/?art=822\&bd=1\&pg=3\&lg>, Acessado em: 26 out. 2011.

. Uma análise da aplicação do Modelo de Empresas Virtuais na

Indústria Brasileira. WZL. Ur Aachen, Alemanha, 1996.

AUSTIN, J.E. Meeting the collabiratiob challenge. In: Workbook by the Peter F.

Drucker Foundation for Nonprofit Management. New York: [sn], 2002.

BRUNTLAND, G.H. Nosso futuro comum. Comissão Mundial sobre o Meio Ambiente e Desenvolvimento. Rio de Janeiro: Fundação Getúlio Vargas, 2. Ed, 1991, p. 431.

BUCKINGHAM, F. The Economist examines the Triple Bottom Line. 2009.

Disponível em:

$<$ http://www.sustainability.com/news/the-economist-examines-the-triple-bottom-line $>$, Acessado em: 20 nov. 2011.

CAMARINHA-MATOS, L. M.; AFSARMANESH, H.; LOEH, H.; STURM, F.; OLLUS, M.; Collaborative networked Organizations: A research agenda for emergin business models, capítulo A Strategic roadmap for advanced virtual organizations. Em: Camarinha-Matos e Afsarmanesh, 2004. 
CAMARINHA-MATOS, L. M.; AFSARMANESH, H. Collaborative networks: Value creation in a knowledge society. In: Wang, K., Kovács, G. L., Wozny, M. J., Fang, M., (edit.), PROLAMAT, Springer, v. 207, 2006, p. 26-40.

CASAROTTO FILHO, N.; PIRES, L.H. Redes de pequenas e médias empresas e desenvolvimento local: estratégias para a conquista da competitividade global com base nas experiências italianas. São Paulo: Atlas, 2ed, 2001, 173 p.

CERVO, A. L.; BERVIAN, P. A. A metodologia científica. São Paulo: Pearson Prentice Hall, 5르. 2002.

DA SILVA, E. L.; MENEZES, E. M. Metodologia da pesquisa e elaboração de dissertação. Florianópolis: UFSC, Universidade Federal de Santa Catarina, 4ํㅡㄹ, 2005, $139 \mathrm{p}$.

ENDERLE, R.A.; CARIO, S.A.F.; NICOLAU, J.A. Estudo do arranjo produtivo local madeireiro do vale do Iguaçu (PR/SC): capacitação tecnológica e política de desenvolvimento. Revista Paranaense de Desenvolvimento. Curitiba, n.108, jan./jun., 2005. p.113-141.

ENDRIGHT, M.J.; Regional clusters and firms strategy. In: Chandlers A. D. Jr.; Hagstrom, P.; Solvell, O.; The dynamic firm. Oxford University Press, 1998.

EUROPEAN COMMISSION. Final report of the expert group on enterprise cluster and networks. European Commission - Enterprise Directorate - General, 2002. Disponível em:

$<$ http://www.dps.tesoro.it/cd_cooperazione_bilaterale/docs/6.Toolbox/13.Supporting _ documents/1.Cluster_methodologies_casoni/2.Additional_doc_2/3.EU_final_rep._Ex pGroup_Clusters.pdf>, Acessado em: 22 jan. 2012.

Observatory of european SMEs. European Commission - SMEs and cooperation, n.5, 2004. Disponível em:

$<$ http://ec.europa.eu/entreprise/enterprise_policy/analysis/observatory_en.htm>, Acessado em: 22 jan. 2012.

FERNANDES B. R. Quem não se comunica não se sustenta! Organicom, ano 7, n. 12, p. 202-205. 1. sem. de 2010. Disponível em <http://revistaorganicom.org.br/sistema/index.php/organicom/article/view/271/351>. Acesso em 5 mar. 2013.

FURLANETTO, E. L. Formação das estruturas de coordenação nas cadeias de suprimento: estudo de caso em cinco empresas gaúchas. Tese de Doutorado, UFRGS, Universidade Federal do Rio Grande do Sul, Rio Grande do Sul, 2002. 
FURTADO, J. Termos e conceitos relacionados ao desenvolvimento sustentável. PROGESA - Programa de Gestão Estratégica Socioambiental. FIA Fundação Instituto de Administração, 2011. Disponível em:

<http://issuu.com/institutojatobas/docs/glossario_ds_jsf_18jul2011_2?mode=window \&pageNumber=22>, Acessado em: 12 mar. 2012.

FRITJOF, C. O ponto de mutação - A ciência, a sociedade e a cultura emergente. São Paulo: Cultrix, 2004, 444 p.

GARCIA, F. B. (2009). Definição da sustentabilidade. Mundo da Sustentabilidade. Disponível em:

$<$ http://sustentabilidades.com.br/index.php?option=com_content\&view=article\&id=30 \&ltemid=50>, Acessado em: 04 abr. 2012.

GEROLAMO, M.C. Gestão de desempenho em clusters e redes regionais de cooperação de pequenas e médias empresas - Estudo de caso brasileiro e alemão e proposta de um modelo de análise. Tese de Doutorado. EESC - Escola de Engenharia de São Carlos, Universidade de São Paulo, São Carlos. 2007.

GIL, A.C. Como Elaborar Projetos de Pesquisa. São Paulo: Atlas, 4ㄹ Ed., 2002, $175 \mathrm{p}$.

GOULART, C.P. Proposta de um modelo de referência para planejamento e controle da produção em empresas virtuais. Dissertação (Mestrado) EESC Escola de Engenharia de São Carlos, Universidade de São Paulo, São Carlos. 2000.

GRANDORI, A.; SODA, G. Inter Firm Networks: antecedents, mechanism and forms. Organization Studies, 16/2, 1995.

GRAY, B. \& WOOD, J. Collaborative alliances: Moving from practice to Theory. Applied Behavioral Science, vol. 27, number 1 and 2, March/June, 1991.

GRI - Global Reporting Initiative. Disponível em:

$<$ https://www.globalreporting.org/reporting/reporting-frameworkoverview/Pages/default.aspx>, Acessado em: 20 out. 2011.

KARVONE, I.; JANSSON, K.; SALKARI, I.; OLLUS, M.; Challenges in the management of virtual organizations. Em: Camarinha-Matos, 2004.

LASTRES, H.M.M.; CASSIOLATO, J.E.; MACIEL, M.L. O foco em arranjos produtivos e inovativos locais de micro e pequenas empresas. In: LASTRES, H.M.M.; CASSIOLATO, J.E.; MACIEL, M.L. (orgs.). Pequena empresa: cooperação e desenvolvimento local. Rio de Janeiro: Relume Dumará, 2003, p.1-10. 
LOSS, L. Um arcabouço para o aprendizado de redes colaborativas de organizações: uma abordagem baseada em aprendizagem organizacional e gestão do conhecimento.. Tese de Doutorado, UFSC, Universidade Federal de Santa Catarina, Santa Catarina. 2007

MACEDO, L. C.. Existe Integração Estratégica entre Sustentabilidade e Comunicação? In: CONFIBERCOM, 1., 2011, São Paulo. Anais. São Paulo: Confibercom, 2011. p. 1. Disponível em: <http://confibercom.org/anais2011/pdf/211.pdf>. Acesso em: 05 mar. 2013.

MIGUEL, P.A.C. Metodologia de pesquisa em engenharia de produção e gestão de operações. São Paulo: Campus, 2009, 248 p.

OLAVE, M. E.L.; AMATO NETO, J. Redes de cooperação produtiva: uma estratégia de competitividade e sobrevivência para pequenas e médias empresas. Revista Gestão e Produção, São Carlos, v.8, n.3, 2001, p.289-303.

OLIVER, C. Determinants of the interorganizational relatioships: integration and future directions. The Academy of Management Review, v.15, n.2, 2009, p.241-265.

PASSOS, S. Networking professional: a percepção dos funcionários participantes do MBA em Gestão Financeira do Banco do Brasil sobre a influência das redes de relacionamento nos processos de seleção interna. Trabalho de conclusão de curso de Especialização de Administração - Universidade Federal do Rio Grande do Sul, porto Alegre, 2004.

POLENSKE, K.R. Competition, Collaboration and Cooperation: An Uneasy Triangle in Networks of Firms and Regions. Regional Studies, vol.38.9, Reino Unido, 2004, p.1029-1043.

PORTER, M.E. Clusters and economic policy: aligning public policy with the new economics of competition. Cambridge: Harvard Business School, 2009, p.110.

REIS, A.P. A dinâmica da aprendizagem em arranjos produtivos locais: um estudo das redes de conhecimento das pequenas e médias empresas de software na construção de suas capacitações. Tese de Doutorado, Escola Politécnica da Universidade de São Paulo, São Paulo. 2008. 
RICCI, A.; OMICINI, A.; DENTI, E. Virtual enterprises and workflow management is agent coordination issues. International Journal of Cooperative Information Systems, v.11, n.3-4, Set./Dez. 2002.

ROBERT, K.H. The Natural Step - A história de uma revolução silenciosa. São Paulo: Cultrix, 2003, 299 p.

SANTA CRUZ, Lucia. O lugar da Comunicação na sustentabilidade. Desafio Sustentável, Rio de Janeiro, v. 1, n. 1, 2009, p.1-10. Disponível em: <http://www.ie.ufrj.br/lares/revista/index.php/desafiosustentavel/article/view/21/7>. Acesso em: 05 mar. 2012.

SAXENIAN, A. Regional advantage: competition and cooperation in Silicon Valley and route 128. Cambridge, Harvard University Press, 1994.

SOARES, A.L.; de SOUZA, J.P.; BARBEDO, F. Modeling the structure of collaborative networks: some contributions. Em: Camarinha-Matos e Afsarmanesh, 2003.

SOUZA, D. Ferramentas de Gestão de tecnologia: um diagnóstico de utilização nas pequenas e médias empresas industriais da região de Curitiba. Dissertação Mestrado em Tecnologia, PPGTE, CEFET, Curitiba, 2003.

SCHMITZ H. Small firms and flexible specialization im LDC's. Sussex, England, Institute of development Studies, 1989.

THE NATURAL STEP. Compêndio para sustentabilidade - Ferramentas de Gestão de Responsabilidade Socioambiental. Disponível em:

<http://www.institutoatkwhh.org.br/compendio/?q=node/102>, Acessado em: 07 mar. 2012.

WAYNE, V. Os 50 + importantes livros em Sustentabilidade. São Paulo: Pereirópolis, 2012, 271 p.

YIN, R.K. Estudo de caso: planejamento e métodos. Porto Alegre: Bookman, 2003, 212 p.. 


\begin{abstract}
ANEXO I
Questionário aplicado para levantamento de informações.

Estrutura de construção do questionário:

A primeira seção apresenta um resumo da empresa: o setor de atuação e seu porte no mercado.

$>$ A segunda seção, questões 01 a 11 do questionário, avalia o grau de maturidade em sustentabilidade. Cada questão possui quatro alternativas de resposta, que estão ordenadas pelo nível de maturidade em sustentabilidade. Primeira resposta com menor nível e a quarta resposta com nível maior de maturidade em sustentabilidade.

$>$ A terceira seção, questões 12 a 14 do questionário, determina o nível de engajamento para colaboração, que estão ordenadas pelo nível de colaboração. Primeira resposta com menor nível e a quarta resposta com nível maior de colaboração.

$>\mathrm{Na}$ quarta seção é descrita as oportunidades, desafios e lições aprendidas ao atuar de forma sustentável.
\end{abstract}




\section{Escola Politécnica da USP \\ Departamento de Engenharia de Produção}

\section{LEVANTAMENTO SOBRE GRAU DE MATURIDADE DAS ORGANIZAÇÕES PARA TRABALHAR COM O TEMA DE SUSTENTABILIDADE DE FORMA COLABORATIVA}

Prezado (a) Senhor (a),

Esta pesquisa tem como objetivo investigar o grau maturidade de organizações para desenvolver projetos de sustentabilidade em colaboração, por meio da identificação do conhecimento sobre sustentabilidade e colaboração.

Dentro desta proposta, temos muito interesse em conhecer melhor a sua organização, suas necessidade e potencialidades. O foco principal desta pesquisa está em identificar o grau atual de maturidade da sua organização e o quanto ela está preparada para trabalhar com o tema de sustentabilidade de forma colaborativa.

Para isso, gostaríamos de poder contar com a sua colaboração em responder esta pesquisa. Sabemos da quantidade de trabalho nas organizações e da escassez de tempo. Porém, sua participação é extremamente valiosa, sem a mesma, perderemos informações de grande relevância.

As informações coletadas serão sigilosas e serão apresentados sem a identificação da empresa e das pessoas que responderam a este questionário.

Desde já, coloco-me à disposição para apresentar os resultados da pesquisa, o que poderá ser feito a partir de junho de 2013.

Obrigada,

Atenciosamente,

Cyntia Watanabe Rosa

Mestranda em Engenharia de Produção

cyntiawr@gmail.com / cyntia@usp.br

O objetivo desta seção é avaliar o quanto as organizações estão maduras para realizar projetos de sustentabilidade em colaboração 


\section{CARACTERÍSTICA DA ORGANIZAÇÃO}

1.1 Setor de atuação:

1.2 Tamanho da empresa, de acordo com o número de funcionários:

$\square$ Grande Porte (acima de 500 funcionários)

$\square$ Médio Porte (100 a 499 funcionários)

$\square$ Pequeno Porte (até 99 funcionários)

1.3País de origem da cultura de gestão da empresa?
$\square$ Brasil
$\square$ França
$\square$ México
$\square$ Espanha
$\square$ Outros

1.4 Cidade onde está localizada a Matriz:

\section{MATURIDADE}

De acordo com a sua percepção, selecione apenas UMA resposta para cada item.

1. A sua organização tem uma clara e articulada definição de sustentabilidade e também uma compreensão de como ela afeta ou afetará seus negócios a curto, médio e longo prazo?

$\square$ Não existe uma definição corporativa de sustentabilidade e o termo é utilizado de diferentes maneiras nos diferentes níveis da organização;

$\square$ Existe uma definição corporativa de sustentabilidade, porém sua utilização não é uniforme em todos os níveis da organização;

Existe uma definição corporativa de sustentabilidade que tem sido mantida pelo conselho e disseminada por todo o Grupo, mas ainda não foi internalizada e totalmente aceita em todos os seus níveis;

$\square$ Existe uma definição corporativa articulada de sustentabilidade com consenso geral e está alinhada em todos os níveis da organização

2. De que forma as mudanças climáticas e a escassez de recursos naturais afetam os negócios da organização?

$\square$ Esses fatores não fazem parte das preocupações estratégicas;

$\square$ Esses fatores preocupam a alta administração, mas ainda não se refletiram nas suas estratégias; 
$\square$ Esses fatores já se refletem em algumas ações estratégicas, mas não existe uma estratégica corporativa global;

$\square$ Mudanças climáticas e escassez de recursos naturais são partes integrantes do planejamento estratégico;

3. A sustentabilidade está incorporada na estratégia do negócio da organização? Não existe uma estratégia clara de sustentabilidade;

Existem iniciativas isoladas que levam em conta aspectos de sustentabilidade, porém sem caracterizar uma estratégia definida (ex. aproveitamento dos resíduos);

$\square$ Existem estratégias definidas para a sustentabilidade em algumas áreas (ex. compras verdes);

$\square$ Existe uma estratégia articulada para sustentabilidade em toda organização;

4. Existe um alinhamento da agenda de sustentabilidade com todos os públicos de interesse da organização? (colaboradores, fornecedores, acionistas, investidores, comunidade, cliente, jornalistas, etc.)?

Pouca comunicação e comprometimento com os públicos de interesse;

São conduzidas algumas campanhas de comunicação e providenciadas ações específicas, porém sem incluir todos os públicos de interesse;

São conduzidos programas extensivos de comunicação junto a alguns públicos de interesse. Porém, somente para alguns assuntos e não de forma consistente e sistemática;

São formadas parcerias e trabalha-se em conjunto com todos os públicos de interesse para tratar de assuntos de sustentabilidade;

5. Quais são os critérios para a identificação dos principais públicos de interesse?

Não há critérios definidos;

Públicos de interesse identificados contratualmente;

Critérios baseados em potencial de litígio;

Matriz de impacto de externalidades;

6. Como funciona o processo de comunicação com os diferentes públicos de interesse?

Notícias veiculadas na mídia (reativo);

Canais de escuta (ex.Ouvidoria e pesquisa de opinião);

Diálogos periódicos na forma de fóruns dedicados aos públicos de interesse;

Canais bidirecionais permanentemente abertos (ex. fale com o presidente);

7. Existe uma política clara de transparência da organização?

$\square$ Não há uma clara política de transparência; 
$\square$ Política de transparência foi concebida, mas não foi implantada;

$\square$ Política de transparência foi implantada, mas não está corretamente divulgada;

$\square$ Política de transparência divulgada para todos os públicos de interesse;

8. A bonificação dos executivos leva em conta fatores ligados à sustentabilidade?

$\square$ A bonificação é baseada somente no resultado econômico a curto prazo;

$\square$ A bonificação é focada no resultado econômico, mas leva em conta resultados socioambiental;

A bonificação considera a gestão de riscos socioambientais (ex. GEE, biodiversidade, etc.);

$\square$ A bonificação está associada a ações que garantam a longevidade do negócio;

9. A estratégia de sustentabilidade da organização está integrada com os processos e operações internas?

$\square$ Não há integração;

$\square$ Existe certa integração entre a estratégia de sustentabilidade com algumas operações e processos;

A estratégia de sustentabilidade está parcialmente incorporada e se reflete em operações fundamentais;

A estratégia de sustentabilidade está totalmente integrada nas operações e processos;

10. Qual a estrutura organizacional da organização para contribuir com o desenvolvimento sustentável?

$\square$ A organização não apresenta uma estrutura definida para a gestão de projetos de sustentabilidade;

A organização possui uma pessoa ou time responsável pela condução da sua participação em iniciativas de sustentabilidade;

A organização possui um gestor dedicado a projetos de sustentabilidade na esfera corporativa com processo e orçamento definidos;

$\square$ A organização tem uma estrutura corporativa dedicada ao desenvolvimento de projetos de sustentabilidade;

11. A organização tem estabelecido metas para suas ações em sustentabilidade, juntamente com indicadores, monitoramento e relatórios?

$\square$ Não existem metas e indicadores para as ações em sustentabilidade;

$\square$ Existem poucas metas e indicadores, e esses possuem divulgação restrita;

$\square$ Existem metas e indicadores implantados, que são periodicamente divulgados; 
Utilizam-se metas e indicadores integrados na gestão do desempenho como parte de uma estratégia de sustentabilidade;

12. Em relação ao nível de integração, como você descreve a forma de envolvimento de sua organização no projeto?

$\square$ Comunicação e troca de informação;

$\square$ Objetivos complementares e alinhamento de atividades;

$\square$ Objetivos compatíveis, identidade individual e trabalho separado;

$\square$ Objetivos comuns, identidades comuns e trabalho conjunto (criação conjunta);

13. Como foi o envolvimento da sua organização?

$\square$ Contribui apenas na realização das atividades operacionais e troca de informações

$\square$ Contribuiu concepção das atividades e realizou individualmente

$\square$ Contribuiu na concepção das atividades e desenvolveu relacionamento com stakeholders

$\square$ Elaborou as atividades em conjunto e comercializou seus produtos

14. Qual o nível de colaboração percebido entre as organizações para o desenvolvimento das ações conjuntas do projeto?

$\square$ Houve envolvimento no desenvolvimento e concepção das atividades

$\square$ Houve envolvimento na execução das atividades

$\square$ Houve envolvimento somente quando ocorreram dificuldades durante o projeto

$\square$ Os envolvimentos ocorreram de acordo com a exigência do contrato

$\square$ Outros

\section{De acordo com a sua percepção, selecione as alternativas possíveis para a questão:}

15. Poderia listar quais as principais dificuldades encontradas na gestão da rede de colaboração?

$\square$ Falta de apoio do Governo

$\square$ Falta de recursos financeiros

$\square$ Falta de recursos adequados para o desenvolvimento de projetos

$\square$ Falta de participação dos membros da rede

$\square$ Falta de colaboração dos executivos das empresas (desconfiança na troca de informações)

$\square$ Falta de integração entre os nós da rede (empresas, universidades, Prestadores de serviço,)

$\square$ Outros 
16. Quais foram as lições aprendidas?

$\square$ Alinhamento com a estratégia do negócio

$\square$ Melhorar a comunicação com o público de interesse

$\square$ Ter maior interação entre os atores envolvidos

$\square$ Necessidade de adaptação dos produtos para atender os públicos identificados $\square$ Outros

17. Quais as oportunidades percebidas para a sua organização?

$\square$ Interação com novos clientes

$\square$ Desenvolvimento de novos produtos

$\square$ Visibilidade da marca da organização

$\square$ Novos negócios

$\square$ Outros 
ANEXO II

\section{Resposta do questionário respondido pelas organizações do Caso 01 - Cadeias Sustentáveis.}

\begin{tabular}{|c|c|c|c|}
\hline Questões & Varejo & Metal-mecânico A & Metal-mecânico B \\
\hline $\begin{array}{l}\text { 1. A sua organização tem uma clara e articulada } \\
\text { definição de sustentabilidade e também uma } \\
\text { compreensão de como ela afeta ou afetará seus } \\
\text { negócios a curto, médio e longo prazo? }\end{array}$ & $\begin{array}{l}\text { Existe uma definição corporativa de } \\
\text { sustentabilidade que tem sido mantida pelo } \\
\text { conselho e disseminada por todo o Grupo, } \\
\text { mas ainda não foi internalizada e totalmente } \\
\text { aceita em todos os seus niveis; }\end{array}$ & $\begin{array}{l}\text { Existe uma definição corporativa de } \\
\text { sustentabilidade que tem sido mantida pelo } \\
\text { conselho e disseminada por todo o Grupo, } \\
\text { mas ainda não foi internalizada e totalmente } \\
\text { aceita em todos os seus niveis; }\end{array}$ & $\begin{array}{l}\text { Existe uma definição corporativa de } \\
\text { sustentabilidade, porém sua utilizaçãa não é } \\
\text { uniforme em todos os niveis da organizaçâa; }\end{array}$ \\
\hline $\begin{array}{l}\text { 2. De que forma as mudanças climáticas e a } \\
\text { escassez de recursos naturais afetam os negócios } \\
\text { da organização? }\end{array}$ & $\begin{array}{l}\text { Mudanças climáticas e escassez de } \\
\text { recursos naturais sâo partes integrantes do } \\
\text { planejamento estratégico; }\end{array}$ & $\begin{array}{c}\text { Esses fatores já se refletem em algumas } \\
\text { açốes estratégicas, mas não existe uma } \\
\text { estratégica corporativa global; }\end{array}$ & $\begin{array}{l}\text { Esses fatores preocupam a alta administração, } \\
\text { mas ainda não se refletiram nas suas estratégias }\end{array}$ \\
\hline $\begin{array}{l}\text { 3. A sustentabilidade está incorporada na } \\
\text { estratégia do negócio da organizaçẫo? }\end{array}$ & $\begin{array}{l}\text { Existem estratégias definidas para a } \\
\text { sustentabilidade em algumas áreas } \\
\text { (ex. compras verdes); }\end{array}$ & $\begin{array}{l}\text { Existem estratégias definidas para a } \\
\text { sustentabilidade em algumas áreas } \\
\text { (ex. compras verdes); }\end{array}$ & $\begin{array}{l}\text { Existem estratégias definidas para a } \\
\text { sustentabilidade em algumas áreas (ex. compras } \\
\text { verdes); }\end{array}$ \\
\hline $\begin{array}{l}\text { 4. Existe um alinhamento da agenda de } \\
\text { sustentabilidade com todos os públicos de } \\
\text { interesse da organização? (colaboradores, } \\
\text { fornecedores, acionistas, investidores, comunidade, } \\
\text { cliente, jornalistas, etc.)? }\end{array}$ & $\begin{array}{l}\text { São conduzidos programas extensivos de } \\
\text { comunicação junto a alguns públicos de } \\
\text { interesse. Porém, somente para alguns } \\
\text { assuntos e não de forma consistente e } \\
\text { sistemática; }\end{array}$ & $\begin{array}{l}\text { São conduzidos programas extensivos de } \\
\text { comunicação junto a alguns públicos de } \\
\text { interesse. Porém, somente para alguns } \\
\text { assuntos e não de forma consistente e } \\
\text { sistemática; }\end{array}$ & $\begin{array}{l}\text { São conduzidos programas extensivos de } \\
\text { comunicação junto a alguns públicos de } \\
\text { interesse. Porém, somente para alguns assuntos } \\
\text { e não de forma consistente e sistemática; }\end{array}$ \\
\hline $\begin{array}{l}\text { 5. Quais são os critérios para a identificação dos } \\
\text { principais públicos de interesse? }\end{array}$ & Matriz de impacto de externalidades; & Não há critérios definidos; & Matriz de impacto de externalidades; \\
\hline $\begin{array}{l}\text { 6. Como funciona o processo de comunicação } \\
\text { com os diferentes públicos de interesse? }\end{array}$ & $\begin{array}{l}\text { Canais bidirecionais permanentemente } \\
\text { abertos (ex. fale com o presidente); }\end{array}$ & $\begin{array}{l}\text { Canais de escuta } \\
\text { (ex. Ouvidoria e pesquisa de opinião); }\end{array}$ & $\begin{array}{l}\text { Noticias veiculadas na midia } \\
\text { (reativo); }\end{array}$ \\
\hline $\begin{array}{l}\text { 7. Existe uma política clara de transparência da } \\
\text { organização? }\end{array}$ & $\begin{array}{l}\text { Política de transparência divulgada para } \\
\text { todos os públicos de interesse; }\end{array}$ & $\begin{array}{l}\text { Politica de transparência divulgada para } \\
\text { todos os públicos de interesse; }\end{array}$ & $\begin{array}{l}\text { Política de transparência divulgada para todos os } \\
\text { públicos de interesse; }\end{array}$ \\
\hline $\begin{array}{l}\text { 8. A bonificação dos executivos leva em conta } \\
\text { fatores ligados à sustentabilidade? }\end{array}$ & $\begin{array}{l}\text { A bonificação é focada no resultado } \\
\text { econômico, mas leva em conta resultados } \\
\text { socioambiental; }\end{array}$ & $\begin{array}{l}\text { A bonificação é focada no resultado } \\
\text { econômico, mas leva em conta resultados } \\
\text { socioambiental; }\end{array}$ & $\begin{array}{l}\text { A bonificação é baseada somente no resultado } \\
\text { econômico a curto prazo; }\end{array}$ \\
\hline $\begin{array}{l}\text { 9. A estratégia de sustentabilidade da organização } \\
\text { está integrada com os processos e operaçốes } \\
\text { internas? }\end{array}$ & $\begin{array}{l}\text { A estratégia de sustentabilidade está } \\
\text { parcialmente incorporada e se reflete em } \\
\text { operaçôes fundamentais; }\end{array}$ & $\begin{array}{c}\text { A estratégia de sustentabilidade está } \\
\text { parcialmente incorporada e se reflete em } \\
\text { operaçôes fundamentais; }\end{array}$ & $\begin{array}{l}\text { Existe certa integração entre a estratégia de } \\
\text { sustentabilidade com algumas operaçốes e } \\
\text { processos; }\end{array}$ \\
\hline $\begin{array}{l}\text { 10. Qual a estrutura organizacional da organização } \\
\text { para contribuir com o desenvolvimento sustentável? }\end{array}$ & $\begin{array}{c}\text { A organização tem uma estrutura corporativa } \\
\text { dedicada ao desenvolvimento de projetos de } \\
\text { sustentabilidade; }\end{array}$ & $\begin{array}{c}\text { A organização tem uma estrutura corporativa } \\
\text { dedicada ao desenvolvimento de projetos de } \\
\text { sustentabilidade; }\end{array}$ & $\begin{array}{c}\text { A organização possui uma pessoa ou time } \\
\text { responsável pela condução da sua participação } \\
\text { em iniciativas de sustentabilidade; }\end{array}$ \\
\hline $\begin{array}{l}\text { 11. A organização tem estabelecido metas para } \\
\text { suas açốes em sustentabilidade, juntamente com } \\
\text { indicadores, monitoramento e relatórios? }\end{array}$ & $\begin{array}{l}\text { Existem metas e indicadores implantados, } \\
\text { que são periodicamente divulgados; }\end{array}$ & $\begin{array}{l}\text { Existem metas e indicadores implantados, } \\
\text { que são periodicamente divulgados; }\end{array}$ & $\begin{array}{l}\text { Existem poucas metas e indicadores, e esses } \\
\text { possuem divulgaçâo restrita; }\end{array}$ \\
\hline $\begin{array}{l}\text { 12.Em relação ao nivel de integração, como você } \\
\text { descreve a forma de envolvimento de sua } \\
\text { organizaçấo no projeto? }\end{array}$ & $\begin{array}{l}\text { Objetivos compativeis, identidade individual e } \\
\text { trabalho separado; }\end{array}$ & $\begin{array}{c}\text { Objetivos complementares e alinhamento de } \\
\text { atividades; }\end{array}$ & $\begin{array}{l}\text { Objetivos complementares e alinhamento de } \\
\text { atividades; }\end{array}$ \\
\hline 13. Como foi o envolvimento da sua organização? & $\begin{array}{c}\text { Contribuiu na concepção das atividades e } \\
\text { desenvolveu relacionamento com } \\
\text { stakeholders }\end{array}$ & $\begin{array}{c}\text { Contribuiu na concepção das atividades e } \\
\text { desenvolveu relacionamento com } \\
\text { stakeholders }\end{array}$ & $\begin{array}{l}\text { Contribuiu na concepção das atividades e } \\
\text { desenvolveu relacionamento com stakeholders }\end{array}$ \\
\hline $\begin{array}{l}\text { 14. Qual o nivel de colaboração percebido entre as } \\
\text { organizaçốes para o desenvolvimento das açôes } \\
\text { conjuntas do projeto? }\end{array}$ & $\begin{array}{l}\text { Houve envolvimento no desenvolvimento e } \\
\text { concepção das atividades }\end{array}$ & $\begin{array}{l}\text { Houve envolvimento no desenvolvimento e } \\
\text { concepçäo das atividades }\end{array}$ & $\begin{array}{l}\text { Houve envolvimento no desenvolvimento e } \\
\text { concepção das atividades }\end{array}$ \\
\hline $\begin{array}{l}\text { 15. Poderia listar quais as principais dificuldades } \\
\text { encontradas na gestão da rede de colaboração? }\end{array}$ & $\begin{array}{l}\text { Falta de recursos financeiros; } \\
\text { Falta de participação dos membros da rede; }\end{array}$ & $\begin{array}{l}\text { Falta de recursos financeiros; } \\
\text { Falta de participação dos membros da rede; }\end{array}$ & $\begin{array}{l}\text { Falta de recursos financeiros; } \\
\text { Falta de recursos adequados para o } \\
\text { desenvolvimento de projetos; }\end{array}$ \\
\hline 16. Quais foram as lições aprendidas? & $\begin{array}{l}\text { Melhorar a comunicaçâa com o público de } \\
\text { interesse; }\end{array}$ & $\begin{array}{l}\text { Melhorar a comunicação com o público de } \\
\text { interesse; }\end{array}$ & Alinhamento com a estratégia do negócio; \\
\hline $\begin{array}{l}\text { 17. Quais as oportunidades percebidas para a sua } \\
\text { organização? }\end{array}$ & $\begin{array}{l}\text { Interação com novos clientes; } \\
\text { Novos negócios; }\end{array}$ & $\begin{array}{l}\text { Desenvolvimento de novos produtos; } \\
\text { Visibilidade da marca da organização }\end{array}$ & $\begin{array}{l}\text { Visibilidade da marca da organização; } \\
\text { Novos negócios; }\end{array}$ \\
\hline
\end{tabular}


ANEXO III

\section{Resposta do questionário respondido pelas organizações do Caso 02 - Rio Cidade Sustentável.}

\begin{tabular}{|c|c|c|c|}
\hline Questões & Construção civil & Eletroeletrônicos & Serviços \\
\hline $\begin{array}{l}\text { 1. A sua organização tem uma clara e articulada } \\
\text { definiçâo de sustentabilidade e também uma } \\
\text { compreensão de como ela afeta ou afetará seus } \\
\text { negócios a curto, médio e longo prazo? }\end{array}$ & $\begin{array}{l}\text { Existe uma definição corporativa articulada } \\
\text { de sustentabilidade com consenso geral e } \\
\text { está alinhada em todos os niveis da } \\
\text { organização }\end{array}$ & $\begin{array}{l}\text { Existe uma definição corporativa } \\
\text { articulada de sustentabilidade } \\
\text { com consenso geral e está } \\
\text { alinhada em todos os niveis da } \\
\text { organizaçâao }\end{array}$ & $\begin{array}{l}\text { Existe uma definição corporativa de } \\
\text { sustentabilidade que tem sido } \\
\text { mantida pelo conselho e disseminada } \\
\text { por todo o Grupo, mas ainda não foi } \\
\text { internalizada e totalmente aceita em } \\
\text { todos os seus niveis; }\end{array}$ \\
\hline $\begin{array}{l}\text { 2. De que forma as mudanças climáticas e a } \\
\text { escassez de recursos naturais afetam os negócios } \\
\text { da organizaçâo? }\end{array}$ & $\begin{array}{l}\text { Mudanças climáticas e escassez de } \\
\text { recursos naturais são partes integrantes do } \\
\text { planejamento estratégico }\end{array}$ & $\begin{array}{l}\text { Esses fatores já se refletem em } \\
\text { algumas ações estratégicas, mas } \\
\text { não existe uma estratégica } \\
\text { corporativa global; }\end{array}$ & $\begin{array}{c}\text { Esses fatores já se refletem em } \\
\text { algumas ações estratégicas, mas não } \\
\text { existe uma estratégica corporativa } \\
\text { global; }\end{array}$ \\
\hline $\begin{array}{l}\text { 3. A sustentabilidade está incorporada na } \\
\text { estratégia do negócio da organização? }\end{array}$ & $\begin{array}{l}\text { Existe uma estratégia articulada para } \\
\text { sustentabilidade em toda organização; }\end{array}$ & $\begin{array}{c}\text { Existe uma estratégia articulada } \\
\text { para sustentabilidade em toda } \\
\text { organizaçấ; }\end{array}$ & $\begin{array}{c}\text { Existe uma estratégia articulada para } \\
\text { sustentabilidade em toda } \\
\text { organização: }\end{array}$ \\
\hline $\begin{array}{l}\text { 4. Existe um alinhamento da agenda de } \\
\text { sustentabilidade com todos os públicos de } \\
\text { interesse da organização? (colaboradores, } \\
\text { fornecedores, acionistas, investidores, comunidade, } \\
\text { cliente, jornalistas, etc.)? }\end{array}$ & $\begin{array}{l}\text { São conduzidos programas extensivos de } \\
\text { comunicação junto a alguns públicos de } \\
\text { interesse. Porém, somente para alguns } \\
\text { assuntos e não de forma consistente e } \\
\text { sistemática: }\end{array}$ & $\begin{array}{l}\text { São formadas parcerias e } \\
\text { trabalha-se em conjunto com } \\
\text { todos os públicos de interesse } \\
\text { para tratar de assuntos de } \\
\text { sustentabilidade; }\end{array}$ & $\begin{array}{l}\text { São conduzidas algumas campanhas } \\
\text { de comunicação e providenciadas } \\
\text { açôes especificas, porém sem incluir } \\
\text { todos os públicos de interesse; }\end{array}$ \\
\hline $\begin{array}{l}\text { 5. Quais são os critérios para a identificaçâo dos } \\
\text { principais públicos de interesse? }\end{array}$ & Matriz de impacto de externalidades; & $\begin{array}{l}\text { Matriz de impacto de } \\
\text { externalidades; }\end{array}$ & Não há critérios definidos; \\
\hline $\begin{array}{l}\text { 6. Como funciona o processo de comunicação } \\
\text { com os diferentes públicos de interesse? }\end{array}$ & $\begin{array}{l}\text { Diálogos periódicos na forma de fóruns } \\
\text { dedicados aos públicos de interesse; }\end{array}$ & $\begin{array}{l}\text { Canais de escuta (ex. Ouvidoria e } \\
\text { pesquisa de opiniâo); }\end{array}$ & $\begin{array}{l}\text { Diálogos periódicos na forma de } \\
\text { fóruns dedicados aos públicos de } \\
\text { interesse: }\end{array}$ \\
\hline $\begin{array}{l}\text { 7. Existe uma politica clara de transparência da } \\
\text { organização? }\end{array}$ & $\begin{array}{l}\text { Política de transparência foi implantada, } \\
\text { mas não está corretamente divulgada; }\end{array}$ & $\begin{array}{l}\text { Política de transparência foi } \\
\text { implantada, mas não está } \\
\text { corretamente divulgada; }\end{array}$ & $\begin{array}{l}\text { Não há uma clara política de } \\
\text { transparência; }\end{array}$ \\
\hline $\begin{array}{l}\text { 8. A bonificação dos executivos leva em conta } \\
\text { fatores ligados à sustentabilidade? }\end{array}$ & $\begin{array}{l}\text { A bonificação é focada no resultado } \\
\text { econômico, mas leva em conta resultados } \\
\text { socioambiental; }\end{array}$ & $\begin{array}{l}\text { A bonificação é baseada } \\
\text { somente no resultado econômico } \\
\text { a curto prazo; }\end{array}$ & $\begin{array}{l}\text { A bonificação é baseada somente } \\
\text { no resultado econômico a curto } \\
\text { prazo; }\end{array}$ \\
\hline $\begin{array}{l}\text { 9. A estratégia de sustentabilidade da organização } \\
\text { está integrada com os processos e operaçőes } \\
\text { internas? }\end{array}$ & $\begin{array}{l}\text { A estratégia de sustentabilidade está } \\
\text { parcialmente incorporada e se reflete em } \\
\text { operaçôes fundamentais; }\end{array}$ & $\begin{array}{c}\text { A estratégia de sustentabilidade } \\
\text { está parcialmente incorporada e } \\
\text { se reflete em operações } \\
\text { fundamentais: }\end{array}$ & Não há integração; \\
\hline $\begin{array}{l}\text { 10. Qual a estrutura organizacional da organização } \\
\text { para contribuir com o desenvolvimento sustentável? }\end{array}$ & $\begin{array}{c}\text { A organização possui um gestor dedicado a } \\
\text { projetos de sustentabilidade na esfera } \\
\text { corporativa com processo e orçamento } \\
\text { definidos; }\end{array}$ & $\begin{array}{c}\text { A organização tem uma } \\
\text { estrutura corporativa dedicada ao } \\
\text { desenvolvimento de projetos de } \\
\text { sustentabilidade; }\end{array}$ & $\begin{array}{l}\text { A organização não apresenta uma } \\
\text { estrutura definida para a gestão de } \\
\text { projetos de sustentabilidade; }\end{array}$ \\
\hline $\begin{array}{l}\text { 11. A organização tem estabelecido metas para } \\
\text { suas açôes em sustentabilidade, juntamente com } \\
\text { indicadores, monitoramento e relatórios? }\end{array}$ & $\begin{array}{l}\text { Existem metas e indicadores implantados, } \\
\text { que são periodicamente divulgados; }\end{array}$ & $\begin{array}{l}\text { Existem metas e indicadores } \\
\text { implantados, que são } \\
\text { periodicamente divulgados: }\end{array}$ & $\begin{array}{l}\text { Não existem metas e indicadores } \\
\text { para as açôes em sustentabilidade; }\end{array}$ \\
\hline $\begin{array}{l}\text { 12. Em relação ao nivel de integração, como você } \\
\text { descreve a forma de envolvimento de sua } \\
\text { organização no projeto? }\end{array}$ & $\begin{array}{c}\text { Objetivos compativeis, identidade individual } \\
\text { e trabalho separado; }\end{array}$ & $\begin{array}{l}\text { Objetivos compativeis, identidade } \\
\text { individual e trabalho separado; }\end{array}$ & Comunicação e troca de informação; \\
\hline 13. Como foi o envolvimento da sua organização? & $\begin{array}{l}\text { Contribuiu concepção das atividades e } \\
\text { realizou individualmente }\end{array}$ & $\begin{array}{l}\text { Contribuiu na concepção das } \\
\text { atividades e desenvolveu } \\
\text { relacionamento com stakeholders }\end{array}$ & $\begin{array}{l}\text { Elaborou as atividades em conjunto e } \\
\text { comercializou seus produtos }\end{array}$ \\
\hline $\begin{array}{l}\text { 14. Qual o nivel de colaboração percebido entre as } \\
\text { organizaçóes para o desenvolvimento das açôes } \\
\text { conjuntas do projeto? }\end{array}$ & $\begin{array}{l}\text { Houve envolvimento na execução das } \\
\text { atividades }\end{array}$ & $\begin{array}{l}\text { Houve envolvimento na execução } \\
\text { das atividades }\end{array}$ & $\begin{array}{l}\text { Houve envolvimento no } \\
\text { desenvolvimento e concepção das } \\
\text { atividades }\end{array}$ \\
\hline $\begin{array}{l}\text { 15. Poderia listar quais as principais dificuldades } \\
\text { encontradas na gestão da rede de colaboração? }\end{array}$ & $\begin{array}{c}\text { Falta de recursos adequados para o } \\
\text { desenvolvimento de projetos; } \\
\text { Falta de participação dos membros da } \\
\text { rede; } \\
\text { Falta de colaboração dos executivos das } \\
\text { empresas (desconfiança na troca de } \\
\text { informaçóes); }\end{array}$ & $\begin{array}{c}\text { Falta de participação dos } \\
\text { membros da rede; } \\
\text { Falta de colaboração dos } \\
\text { executivos das empresas } \\
\text { (desconfiança na troca de } \\
\text { informaçốes); } \\
\text { Alinhamento com a estratégia do } \\
\text { negócio; }\end{array}$ & $\begin{array}{l}\text { Falta de apoio do Governo; } \\
\text { Falta de participação dos membros } \\
\text { da rede; } \\
\text { Falta de integração entre os nós da } \\
\text { rede (empresas, universidades, } \\
\text { Prestadores de serviço,); } \\
\text { Alinhamento com a estratégia do } \\
\text { negócio; }\end{array}$ \\
\hline 16. Quais foram as lições aprendidas? & $\begin{array}{l}\text { Melhorar a comunicação com o público de } \\
\text { interesse; } \\
\text { Ter maior interaçâa entre os atores } \\
\text { envolvidos; }\end{array}$ & $\begin{array}{l}\text { Melhorar a comunicação com o } \\
\text { público de interesse; } \\
\text { Ter maior interação entre os } \\
\text { atores envolvidos; }\end{array}$ & $\begin{array}{l}\text { Necessidade de adaptação dos } \\
\text { produtos para atender os públicos } \\
\text { identificados; }\end{array}$ \\
\hline $\begin{array}{l}\text { 17. Quais as oportunidades percebidas para a sua } \\
\text { organização? }\end{array}$ & $\begin{array}{l}\text { Desenvolvimento de novos produtos; } \\
\text { Visibilidade da marca da organização; } \\
\text { Engajamento do publico interno em projetos } \\
\text { de grande interesse; }\end{array}$ & $\begin{array}{l}\text { Interação com novos clientes; } \\
\text { Desenvolvimento de novos } \\
\text { produtos; } \\
\text { Visibilidade da marca da } \\
\text { organização; }\end{array}$ & $\begin{array}{l}\text { Visibilidade da marca da } \\
\text { organização; } \\
\text { Novos negócios; }\end{array}$ \\
\hline
\end{tabular}

